\title{
Anamorfoses na música eletroacústica mista
}

\author{
Tiago Gati
}

GATI, T. Anamorfoses na música eletroacústica mista [online]. São Paulo: Editora UNESP; São Paulo: Cultura Acadêmica, 2015, 165 p. ISBN 978-85-7983-707-4. Available from SciELO Books $<\underline{\text { http://books.scielo.org }>\text {. }}$

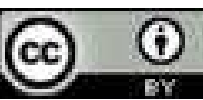

All the contents of this work, except where otherwise noted, is licensed under a Creative Commons Attribution 4.0 International license.

Todo o conteúdo deste trabalho, exceto quando houver ressalva, é publicado sob a licença Creative Commons Atribição $\underline{4.0}$.

Todo el contenido de esta obra, excepto donde se indique lo contrario, está bajo licencia de la licencia Creative Commons Reconocimento 4.0. 


\section{ANAMORFOSES NA MUSICA ELETROACÚSTICA MISTA}

TIAGO GATI 


\section{Anamorfoses na mÚsica ELETROACÚSTICA MISTA}


Conselho Editorial Acadêmico

Responsável por esta publicação

Graziela Bortz

Marcos Fernandes Pupo Nogueira

Nahim Marin Filho

Ricardo Lobo Kubala 


\section{TIAGO GATI}

\section{AnAmorfoses NA MÚSICA \\ ELETROACÚSTICA MISTA}


(C) 2015 Editora Unesp

\section{Cultura Acadêmica}

Praça da Sé, 108

01001-900 - São Paulo - SP

Tel.: (0xx11) 3242-7171

Fax: (0xx11) 3242-7172

www.editoraunesp.com.br

www.livrariaunesp.com.br

feu@editora.unesp.br

CIP - BRASIL. CATALOGAÇÃO NA PUBLICAÇÃO

SINDICATO NACIONAL DOS EDITORES DE LIVROS, RJ

\section{G234a}

Gati, Tiago

Anamorfoses na música eletroacústica mista / Tiago Gati. São Paulo:

Cultura Acadêmica, 2015.

Recurso digital

Formato: ePub

Requisitos do sistema: Adobe Digital Editions

Modo de acesso: World Wide Web

ISBN 978-85-7983-707-4 (recurso eletrônico)

1. Música eletrônica. 2. Eletroacústica. 3. Livros eletrônicos. I. Título.

$15-28928$

CDD: 786.74

CDU: 78

Este livro é publicado pelo Programa de Publicações Digitais da Pró-Reitoria de Pós-Graduação da Universidade Estadual Paulista "Júlio de Mesquita Filho" (UNESP)

Editora afiliada:

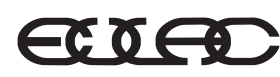

Asociación de Editoriales Universitarias de América Latina y el Caribe

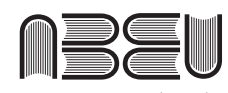

Associação Brasileira de Editoras Universitárias 


\section{Agradecimentos}

O projeto deste livro teve origem em minha dissertação de mestrado apresentada no Instituto de Artes da Unesp em 2014, sob orientação do professor Flo Menezes, com apoio financeiro da Capes.

Gostaria de agradecer, primeiramente, ao Flo, pelas críticas precisas, sem rodeios e construtivas, pelas reuniões e discussões intensas ao longo de todo o caminho, além dos detalhes e contribuições preciosos sobre Parcours de l'Entité, obra sua analisada na segunda parte do livro.

Agradeço também à minha família, especialmente à Patricia, pelo apoio e paciência desde muito antes do início do trabalho; aos queridos e excelentes músicos que colaboraram para a realização e estreias das composições que acompanharam a pesquisa, além de testes, ensaios e estudos: Leonardo Bertolini Labrada, Elissa Cassini, Claudio Cruz, Charles Augusto e Zacarias Maia; ao Alexandre Lunsqui, pelas discussões extremamente revigorantes; ao Silvio Ferraz, pelas contribuições ao desenvolvimento teórico e composicional realizado; aos professores que muito ajudaram no percurso deste trabalho: Alberto Ikeda, Carlos Stasi e Leonardo Aldrovandi; ao Bruno Ruviaro, por fornecer materiais musicais e pelo diálogo aberto; ao Francesco Giomi (diretor do Centro Tempo Reale, em Florença), pela gentil disponibilização de materiais preciosos para a análise de Altra 
voce, de Luciano Berio; ao André Perrotta, pela elaboração, colaboração e inúmeras reelaborações das programações em MAX/MSP de Nomoi, obra desenvolvida e estreada durante a pesquisa. Por fim, um agradecimento especial à Universal Edition pelos exemplos da partitura de Altra voce, obra de Luciano Berio abordada neste livro. 


\section{SUMÁRIO}

Agradecimentos 5

Introdução 9

PARTE I 17

1 O gesto musical na composição eletroacústica mista 19

2 Anamorfoses na música eletroacústica mista 47

Parte II 75

3 Análises musicais 77

4 Abertura 149

Referências bibliográficas 161 


\section{INTRODUÇÃO}

Tomando a evolução dos instrumentos musicais pelo viés da cultura europeia, a natureza da relação humana com seus meios de fazer música mostra alguns aspectos marcantes: os instrumentos, máquinas criadas para produzir sons com as mais diversas características, podem ter sido inicialmente construídos a partir de modelos baseados em fontes emissoras de sons, como a voz ou o toque percussivo causado por um movimento corporal qualquer; e, do aperfeiçoamento da técnica, do como tocar este instrumento, que também cria novas necessidades de evolução da máquina, desprende-se autônoma a própria luteria, ou seja, a tecnologia de criação e aperfeiçoamento do instrumento em si. Mas permeando as tentativas de replicar uma fonte emissora ou de um desejo pelo aprimoramento da qualidade do som emitido, um pensamento musical constitui terreno comum entre ambos, motiva escolhas, delimita campos de atuação para a possível construção de um discurso, alimenta-se e funda-se nesta relação possível entre técnica e desejo, produção sonora e sua contextualização em uma retórica. ${ }^{1}$

1 Preferimos o uso do termo retórica quando sugere intenção, atitude em relação a um objeto (neste caso o som), que acaba por ensejar um discurso, e menos com relação à indução manipuladora. 
Em uma menção interessante na Encyclopédie, editada por Diderot e d'Alembert, especula-se sobre esta possível origem dos instrumentos musicais: "os instrumentos de música consistem em máquinas inventadas e organizadas pela arte do luthier para exprimir os sons não vocais, ou para imitar a voz natural do homem, ou para embelezá-la e acompanhá-la" (Diderot; d'Alembert, 1785, p.1). ${ }^{2}$ É fato que o desenvolvimento de novas tecnologias aplicáveis aos instrumentos musicais também influenciaram o fazer musical, demandando não só adaptações de execução, mas também realimentando um ciclo que envolve a técnica, por um lado (desmembrada em tecnologia do instrumento enquanto máquina e a própria técnica do instrumentista), e o pensamento musical e a busca por sonoridades, por outro, mesclando-se para levar adiante a atividade musical como um todo.

Certamente houve, desde sempre, máquinas musicais com modos de acionamentos diversos e inusitados, alguns até mais próximos do acionamento de um mecanismo em si que propriamente da execução instrumental, como no caso da serinette (espécie de caixa de música acionada por manivela). Outros instrumentos como a viela de roda (que entrou em desuso a partir do século XVIII na Europa), acionada por uma manivela que friccionava suas cordas, ou o régale, instrumento de teclado acionado por foles acoplados e utilizado por Monteverdi em obras como Orfeo, frequentemente necessitavam de uma segunda pessoa para acionar o mecanismo de produção sonora, o que nos sugere um paralelo com a presença do técnico de som para regulagens de equilíbrio, níveis e acionamento de processos na música contemporânea envolvendo recursos eletrônicos.

O século XX, que viu radicais transformações proliferarem-se em diversas áreas do conhecimento científico, inundou o fazer musical com uma vasta gama de possibilidades - talvez porque tenhamos mais registro das experiências no século ou porque de fato tenha

2 No original: "Les instruments de musique sont des machines inventées $\mathcal{E}$ disposées par l'art du luthier, pour exprimer les sons au défaut des voix, ou pour imiter la voix naturelle de l'homme, ou pour l'embellir et l'accompagner". 
ocorrido uma efervescência com poucos precedentes comparáveis. Das mais distintas ferramentas levadas ao convívio dos músicos às conquistas em áreas do saber como filosofia e psicologia, a atividade musical atravessa um período de profunda experimentação e transformação, especialmente quando consideramos a incorporação dos recursos eletromecânicos e eletrônicos nas suas realizações. A partir daí, a natureza da relação humana com estas máquinas de fazer música e produzir sons sofre gradualmente a intermediação de modos de acionamento e processos que não necessariamente se referem a gestos musicais tais como foram mais sedimentados historicamente; a noção mesma de instrumento musical passa a ser repensada, ${ }^{3}$ uma vez que as máquinas conhecidas para fazer música sofrem a influência ou são acopladas a novas máquinas até a sedimentação de processos indiretos de produção sonora, isto é, que não envolvem a situação de tocar um instrumento, mas sim de realizar sons por meio de algoritmos computacionais ou por manipulação direta do som tornado objeto por meio da gravação. A própria luteria, em sua acepção clássica, perde espaço na atividade musical, já que forjar sons com diversos meios é tanto parte da atuação cotidiana do compositor quanto do intérprete contemporâneo.

Já em um texto de 1936, Edgar Varèse revela esse desejo pela utilização de meios tecnológicos não usuais na atividade musical, e transparece um anseio por ferramentas capazes de incorporar um maior controle do espaço e da distribuição de planos sonoros ${ }^{4}$ :

3 Pierre Schaeffer, em seu Traité des objets musicaux (1966), dedica uma longa consideração a este respeito como ponto de partida para analisar relações entre os corpos emissores de sons e o objeto sonoro em si. Embora este tema seja extremamente controverso e de enorme complexidade, não sendo obviamente o nosso foco, vale a menção de que há diversos estudos investigando a noção de instrumento a partir das teorizações de Schaeffer, como no caso das orquestras de laptops, partindo do princípio de que elas se aproximam do universo instrumental dos pontos de vista da presença, movimento (ação do corpo humano) e repertório (história e traçados culturais que envolvem a sedimentação de um instrumento) (Ruviaro, 2012, p.23).

4 Daqui em diante, datas de publicações citadas entre colchetes serão referentes à publicação original, quando disponível. 
Hoje, com meios técnicos que já existem e que são facilmente adaptáveis à música, é possível tornar perceptível ao ouvinte, por meio de determinadas sutilezas acústicas, a diferenciação entre massas, planos e faixas sonoras. Tais sutilezas acústicas permitirão, no mais, a delimitação daquilo que designo por "zonas de intensidades". Essas zonas serão diversificadas mediante diferenças de timbre e de intensidade, e por meio de tal processo físico, no que diga respeito à sua percepção, assumirão cores, dimensões e perspectivas diferentes [...] Tais zonas serão percebidas como isoladas umas das outras, e sua separação (ou a sensação de uma separação entre elas) tornar-se-á finalmente possível. (Varèse [1936] in Menezes, 2009 [1996], p.58)

Outros trabalhos na área já realizaram um mapeamento histórico da chamada música eletroacústica mista - presença e atuação conjunta de corpos instrumentais e meios eletroacústicos - desde suas origens mais esparsas, que remontam até mesmo a uma produção "pré-era eletroacústica" propriamente dita: ${ }^{5}$ equipamentos eletromecânicos para gerar sons por meio de alto-falantes acompanhando ou não sons instrumentais já sedimentados, como os intonarumori desenvolvidos por Luigi Russolo à época do Futurismo (191314); ${ }^{6}$ o uso de sirenes por Edgar Varèse (Ionization, 1929-31), sinos

5 O uso do termo eletroacústico surgiu, de fato, bem antes do período em que houve uma produção tão significativa a ponto de justificar a origem propriamente dita da música eletroacústica como um gênero musical, ou seja, fins dos anos 1940. Um exemplo: "o fato de que [Arthur] Hoérée falou, em 1934, de sons organizados, técnicas de manipulação de sons gravados e de técnicas 'eletroacústicas' pode ser um indicador do quão a sério ele levou Varèse" (Mattis, 1992, p.565).

6 Stravinsky, que parece ter ouvido com entusiasmo os intonarumori em 1914 (Payton, 1976), revela uma curiosa anedota sobre um encontro com Russolo e Pratella em 1915, em Milão: "Cinco fonógrafos sobre cinco mesas em um amplo salão emitiam ruídos de digestão, estática etc., assustadoramente similares à musique concrète de sete ou oito anos atrás (talvez eles fossem mesmo futuristas, enfim) [...] Eu demonstrei estar entusiasmado e disse-lhes que cinco fonógrafos, com tal música e produzidos em larga escala, certamente seriam vendidos como grandes pianos Steinway" (Stravinsky apud Payton, 1976, p.28). 
elétricos e até hélices de avião por George Antheil (Ballet mécanique, 1923); fonógrafos difundindo sons de pássaros em meio ao ambiente orquestral por Ottorino Respighi (Pini di Roma, 1924) e toca-discos por John Cage (Imaginary Landscape I, para piano, prato e dois toca-discos, 1939), para citar alguns. Mas é na década de 1950 que se instituem as chamadas primeiras obras eletroacústicas mistas: Bruno Maderna (Musica su Due Dimensione, para flauta e fita magnética, 1952, com uma segunda versão realizada em 1958); Henri Pousseur (Rimes pour Différentes Sources Sonores, para três grupos orquestrais e fita magnética, 1958-59); Pierre Boulez (Poésie pour pouvoir, para fita magnética em cinco canais e três grupos orquestrais, 1958); Luciano Berio (Différences, para flauta, clarinete, viola, violoncelo, harpa e fita magnética, 1958-59) e Karlheinz Stockhausen (Kontakte, para piano, percussão e fita magnética, 1959-60) (Menezes, 1998, 2009 [1996]; Manning, 2003; Chadabe, 1997).

Mesmo em face de uma enorme diversidade de repertório e práticas musicais com recursos eletroacústicos, o que se tem mais estabelecido desde os primórdios dessas experiências com equipamentos eletromecânicos envolvendo instrumentos musicais tocados ao vivo são diferenças na natureza da interação entre dois meios: o instrumental, por um lado, que envolve em algum nível tocar um instrumento musical, seja ele um instrumento mais ou menos sedimentado no repertório, implicando uma relação direta, sem intermediações, entre a manipulação deste instrumento e seu resultado sonoro (forte causalidade); e o eletroacústico, por outro, que implica inserir elementos intermediários entre o músico e o resultado sonoro (controladores e processadores de sinal, sensores, até mesmo o próprio microfone e o alto-falante), abarcando desde a difusão de materiais pré-elaborados em estúdio até sistemas ou processos em alto grau de interação ao vivo com o intérprete musical. E se as máquinas de hoje, tanto os instrumentos quanto os processos eletroacústicos, são capazes de amalgamar-se mais e mais, por vezes confundindo-se uns com os outros, isso não diminui ou mesmo invalida as peculiaridades e a autonomia da música eletroacústica no contexto da música mista: tal autonomia, que será tratada em mais detalhes no Capítulo 1, 
fica mais patente nos casos em que há claro contraste com a contraparte instrumental.

Esta observação faz-se necessária uma vez que termos como interação, música instrumental, música computacional, eletroacústica, concerto, música interativa, entre tantos outros, encontram-se presentes na produção musical recente tanto como delimitação de gênero quanto para categorizar obras específicas. A diversidade de termos encontrada na literatura - e sua constante reelaboração - revela não somente a dificuldade de consenso e de cunhar uma terminologia definitiva, mas também a vasta gama de aplicações e maneiras como a interação musical com meios eletrônicos vem ocorrendo. Tendo isso em vista, procurei manter o uso do termo música eletroacústica mista com a acepção da música contemporânea que advém da tradição da música de concerto, englobando vários níveis de interação, o que pode varrer desde a difusão por tempo diferido - isto é, a difusão de sons compostos previamente em estúdio - até o processamento sonoro em tempo real - durante a performance.

Antes de adentrar propriamente o objeto deste trabalho, que tratará de um aspecto bastante proeminente da música eletroacústica mista, por ora denominado genericamente de anamorfose, convém traçar um breve panorama do que exatamente se incorpora no fazer musical com recursos eletrônicos, e quais são algumas das peculiaridades e possibilidades que se apresentam ao compositor. A música eletroacústica constituiu um campo próprio da experiência musical e mantém características particulares, seja na qualidade de emissão sonora, na dinamização espacial, nas transformações e transfigurações possíveis sobre o envelope dinâmico ou a caracterização espectral de um som. Antes de qualquer coisa, o aparato eletroacústico possibilita expansões dos meios instrumentais em diferentes aspectos: alterações mais ou menos sutis podem conferir a camadas ou eventos sonoros trajetórias espaciais precisas, diferenciação de planos e profundidades com alto controle, alterações e transformações espectrais da produção sonora mais característica de um instrumento sendo executado, entre outros. Um apanhado sobre estas peculiaridades do aparato eletroacústico, especialmente sob a 
luz de um pensamento "acusmático", podemos dizer - principalmente a partir de François Bayle -, será realizado no Capítulo 1, que abre a Parte I do trabalho. Esse capítulo tratará ainda de um conceito que, embora extremamente amplo e aplicado a diversos campos da atividade musical, nos será fundamental: o gesto, que contribuirá tanto para fundamentar teoricamente a anamorfose quanto para as análises presentes no texto.

O trabalho foi dividido em duas grandes partes: a primeira, contendo os dois capítulos iniciais, é mais voltada ao desenvolvimento teórico a partir da problemática das anamorfoses. A segunda parte, composta pelos capítulos 3 e 4, apresenta uma abordagem prática com a análise musical de duas obras.

No Capítulo 2 entrarei mais especificamente no principal objeto desta pesquisa: as anamorfoses, das origens do termo no campo visual, passando pela definição de Pierre Schaeffer sobre as anamorfoses temporais e funcionais, até a proposição feita aqui para o uso generalizado do termo aplicado à música eletroacústica mista.

O Capítulo 3 inaugura a segunda parte do trabalho e é dedicado a duas situações em que são analisadas as anamorfoses: Parcours de l'Entité (1994), de Flo Menezes, e Altra voce (1999), de Luciano Berio. Foi realizado um recorte dentro do repertório da música mista que seja mais representativo dos argumentos propostos ao longo do texto, obviamente não havendo a pretensão de realizar uma ampla catalogação do repertório, mas apenas de extrair casos que foram considerados típicos da problemática identificada. As duas obras foram consideradas bastante representativas de dois aspectos distintos das anamorfoses na música mista:

1) Altra voce (1999), de Luciano Berio, para flauta contralto, mezzo-soprano e eletrônica em tempo real, mostra-nos bem uma intenção sutil de expandir o universo instrumental e dinamizá-lo no espaço. Altra voce é uma espécie de recontextualização da cena $\mathrm{Il}$ Campo de Cronaca del Luogo (também de 1999), de Berio. À parte as adaptações do ponto de vista da estruturação musical de uma obra à outra, destaca-se a radical reconfiguração no espaço da performance, repensado com auxílio de recursos eletrônicos em tempo 
real (live-electronics), constituindo uma questão central na poética de Berio durante o período do Centro Tempo Reale, fundado por ele em 1987.

2) Parcours de l'Entité (1994), de Flo Menezes, para flautas, percussão e sons eletroacústicos, fortemente representativa do ponto de vista da composição de cenas, ou, como veremos adiante, situações na música mista: há "percursos" pelo palco atribuídos ao flautista, gestos cênicos específicos indicados na partitura que agregam à apresentação ao vivo não só ações meramente ilustrativas das transformações do material musical, mas configuram-se como elementos visuais que potencializam novos fluxos na construção de significados e campos de ambiguidades.

O Capítulo 4, intitulado "Abertura", abre caminho para a continuidade do tema, seja de uma perspectiva teórica, seja do ponto de vista composicional. São formulados aí pensamentos acerca do espaço da performance da música mista, incluindo elementos extramusicais que, previstos pelos compositores - e idealizados e realizados ou não por eles na performance -, enfatizam as anamorfoses na música mista. A abertura também se deve ao fato de que as obras mencionadas neste livro relacionam-se preponderantemente às anamorfoses no âmbito das morfologias sonoras em si. O interesse no caso de uma obra como Parcours de l'Entité, por exemplo, permeada por elementos extramusicais em uma preocupação patente com a "cena" musical da performance, é que vislumbram-se trabalhos futuros composicionais e teóricos - que permitiriam aprofundar a noção de espaço da performance na música mista. 
Parte I 


\section{1 \\ O GESTO MUSICAL NA COMPOSIÇÃO ELETROACÚSTICA MISTA}

\section{O gesto musical na composição eletroacústica mista a partir do pensamento acusmático}

A cadeia eletroacústica produz, a partir de uma matéria real, verdadeiras "transformações": imagens. Nós as escutamos por elas mesmas, sem o amparo da visão. Sua única coerência: suas próprias morfologias; em qualquer contexto: sua própria retórica de imagens. Eis a situação "acusmática".

François Bayle $^{1}$

É preciso enfatizar que os meios eletroacústicos agregados à execução instrumental conservam sua autonomia, suas peculiaridades. E para visualizarmos com maior clareza tais particularidades, observaremos por um instante o universo da chamada música acusmática,

1 No original: "La chaîne électro-acoustique, à partir d'une matière réelle produit des 'transformées': des images. On les écoute pour elles-mêmes, sans le secours de la vue. Leur unique cohérence: celle de leurs propres morphologies; pour tout contexte: leur propre rhétorique d'image. C'est la situation 'acousmatique"' (Bayle, 1993, p.80). 
cuja realização ocorre por meio de alto-falantes que, em geral, tendem a uma supremacia frente à presença humana na performance. ${ }^{2}$

Com efeito, desde o fundamento essencial do termo acusmático, atribuído inicialmente a Pitágoras e referente a uma escuta sem ver, pensa-se em uma postura de separar os sons de sua origem, de ouvi-los distanciados de uma causa conhecida. ${ }^{3}$ François Bayle expressa que, muito embora a experiência acusmática tenha ocorrido antes e em outros campos como na telefonia e radiofonia, foi precisamente na música que se observou sua potencialização mais profunda e radical; o meio radiofônico atuaria como um tipo de mediatização, registro ou forma "banal" da acusmática, por sua conexão direta com uma realidade visível. A originalidade da música acusmática estaria precisamente em abrir "a representação do mundo acusmático sui generis", trazendo o som em si como fonte de significação, substituindo de vez o objeto por sua imagem sonora.

O disco e a rádio nos revelam continuamente o modo banal da acusmática. Sabe-se que nesta escuta, por uma saturação constante de índices, trata-se apenas de uma pura comodidade de mediação. [...] Desta situação banalizada desprende-se, e se opõe claramente, o caso bastante original da representação do mundo acusmático sui generis. Todas as capacidades de uma técnica que substitui ao objeto sua imagem adquirem aí o estatuto de uma retórica. Montagem, extração, inserção, ilustração, ampliação, mas também cesura do tempo, dilaceração dos lugares, mas também mixagem, sobreimpressão, metamorfose de contornos e, enfim, introdução da velocidade do

2 Falar em supressão total do intérprete parece ser por demais generalizante, uma vez que concertos de música acusmática podem adquirir várias formas e diversos graus de "presença" humana: espacialização ao vivo com ferramentas altamente gestuais, ou a própria criação dos sons ao vivo - ver, por exemplo, as orquestras de laptops e o uso do termo live acousmatics com a utilização de interfaces gestuais de geração sonora.

3 Inúmeros autores fazem referência a esta definição. Para maiores detalhes, ver Bayle (1993); Menezes (2009); Wishart (1986). 
movimento e do próprio espaço, tornam-se então recursos e conteúdo, meio e mensagem. (Bayle, 1993, p.50-1) ${ }^{4}$

Os limites das relações de causa e efeito do corpo sonoro, das relações da máquina com a presença humana na performance, da dilaceração do espaço e do tempo, da reinserção de universos sonoros advindos de outros tempos e lugares, conferem aos meios eletroacústicos, quando combinados ao universo instrumental, a peculiaridade de poderem virtualizar a situação da performance, poderem ampliar aquela "realidade" física possível.

Tal foi a abertura criada pela possibilidade de o compositor fazer música diretamente manipulando equipamentos eletrônicos, sem a presença de intérpretes ou mesmo prescindindo da necessidade de decodificação por uma partitura, que, já no início dos anos 1950, foi estabelecida a diferenciação em "duas dimensões" do material sonoro claramente distintas: uma "instrumental", por um lado, e uma eletroacústica, por outro. Esta diferenciação passou por uma evolução bastante considerável tanto no campo técnico quanto no desenvolvimento do repertório musical envolvendo as esferas instrumental e eletroacústica, em que ambas influenciaram uma à outra. Escutando obras mistas como Déserts de Varèse ou a própria Musica su Due Dimensioni de Maderna, dos anos 1950, é clara esta diferenciação radical entre as duas esferas. O trabalho em estúdio permitiu ainda que um evento sonoro pudesse ser isolado no tempo, sendo assim passível de análise microscópica e de diversas transformações; um corpo sonoro torna-se, em primeira instância,

4 No original: "Le disque, la radio nous révèlent sans cesse le mode banal de l'acousmatique. À cette écoute, on sait, par une saturation constante d'indices, qu'il ne s'agit que d'une pure commodité de médiation. [...] De cette situation banalisée se dégage, et s'y oppose évidemment, le cas fort original de la représentation du monde acousmatique sui generis. Toutes les capacités d'une technique qui substitue à l'objet son image, y acquièrent alors le statut d'une rhétorique. Montage, extraction, insertion, illustration, grossissement, mais aussi brisure du temps, éclatement des lieux, mais encore mixage, surimpression, métamorphose de contours, mais enfin introduction de la vitesse et de l'espace, deviennent alors ensemble moyens et contenus, médium et message". 
objeto - já que pode ser fixado no tempo -, para então passar à imagem, a poder distanciar-se de sua origem concreta e fazer parte de um contexto musical pelos seus atributos espectrais em si e seus contornos.

Com a inegável transformação (influência seria dizer o mínimo) exercida pela experiência em estúdio na composição musical em geral a partir dos anos 1950, estabeleceu-se uma verdadeira via de mão dupla entre a escritura instrumental e a eletroacústica, pela qual ambas se realimentam, se influenciam. Notadamente por meio da experiência da música acusmática, semearam-se de maneira mais intensa abordagens composicionais que tomavam os eventos sonoros em si, seus contornos, sua distribuição e caracterização espectral como ponto de partida para a estruturação musical. ${ }^{5}$ Em um texto de 1980 - The Revolution of Complex Sounds [A revolução dos sons complexos], Tristan Murail expõe esta diferença essencial que a escritura musical adquire, passando a incorporar modelos do som em si, constituindo alternativas à parametrização sonora excessiva tal como vista nas técnicas estritamente seriais, por exemplo:

Toda tentativa de integrar estes novos sons que, como veremos, são sobretudo sons de um caráter "complexo", exige uma revisão profunda das técnicas compositivas tradicionais (por "tradicionais" entendo as técnicas seriais, aleatórias, estocásticas etc., que

5 Este tipo de modelo já havia sido adotado antes do surgimento da música eletroacústica, como no repertório de obras para percussão da primeira metade do século XX. A obra clássica de Edgar Varèse Ionization, de 1929-31, foi uma das primeiras obras a explorar sistematicamente aspectos da constituição espectral como funções estruturais da composição antes do advento da era eletrônica na música. Além de contar com células rítmicas como material estrutural, a ausência de alturas definidas (a não ser ao final da obra) certamente valoriza outros aspectos como timbre, textura e perfis. Varèse cria grupos de acordo com características sonoras de cada instrumento e utiliza esta organização como critério estrutural na composição. As ideias rítmicas são, desta maneira, combinadas às "cores" instrumentais - a cor não como ornamento, mas como elemento estrutural, em uma correlação com o que ocorreu paralelamente na pintura moderna - para compor a escritura da obra. 
continuam utilizando esquemas antiquados de parametrização) e da nossa concepção mesma do ato de compor. (Murail, 1980, p.21)

O desenvolvimento dos processos de análise e manipulação do som em estúdio foi sedimentando mais e mais a ideia de que os chamados parâmetros do som eram de fato altamente intercambiáveis, compondo um continuum sonoro. Eé a partir desta constatação fundamental que o gesto musical passa a se "descolar" de uma atuação exclusivamente instrumental, passa a adquirir atributos da morfologia do som em si, de suas trajetórias energéticas próprias.

A supressão da visão associada à música acusmática também parece ter influenciado substancialmente a música instrumental: de fato, cria-se um conflito direto com uma postura diante da performance extremamente calcada na visualização do gesto instrumental ou associação direta a ele -, visão esta até hoje bastante proeminente em vários círculos musicais. É curioso notar, no livro autobiográfico Chroniques de ma vie, que Stravinsky destaca uma importância crucial e até mesmo uma preferência por ver a performance instrumental, a atuação do intérprete. Ao descrever a estreia de História do Soldado (1918), o compositor mostra uma preocupação marcante com a disposição e caracterização dos intérpretes no palco:

Outra coisa levou-me a esta ideia particularmente atraente, isto é, o interesse que constitui para o espectador a visibilidade dos instrumentistas, cada um a desempenhar seu papel concertante. Porque eu sempre abominei escutar música com os olhos fechados, sem uma parte ativa do olhar. A imagem do gesto e do movimento das diferentes partes do corpo que a produzem é uma necessidade

6 No original: "any attempt to integrate these new sounds that are above all, as we shall see, sounds of a 'complex' character, necessitates a profound revision of traditional compositional techniques (by 'traditional' I include serialism, aleatoric composition, stochastic composition etc.: techniques that continue to use antiquated grids of parameters) and of our very conception of the compositional act". 
essencial para apreendê-la em toda a sua extensão. (Stravinsky, 1962, p.91-2) ${ }^{7}$

A visão de Stravinsky evidentemente marca traços de sua própria experiência como compositor em determinada época e em um contexto, mas o que mais nos interessa no discurso dele é esta concepção de que ver o gesto instrumental - à parte as "gesticulações supérfluas" -, associar diretamente o corpo que se movimenta ao resultado sonoro que se obtém, que até contribui para a apreensão global e "facilita a percepção auditiva" (idem, ibidem), foi uma visão posta em xeque especialmente com a consolidação da música acusmática.

\section{Gesto, memória e erosão}

De uma perspectiva distinta daquela apontada em Stravinsky, ou seja, mais próxima a uma postura de distanciar o material sonoro de sua origem, de uma causa conhecida, de um corpo, recorreremos a uma noção extremamente ampla em música, mas que nos servirá de base para compreender melhor o já mencionado "modelo do som", a diluição de parâmetros e o distanciamento em relação ao modelo puramente instrumental: o gesto. $\mathrm{O}$ som torna-se um corpo em si mesmo, ou melhor, uma imagem que singulariza a morfologia de um objeto sonoro como um todo. Muito embora esteja presente em contextos diversos, em inúmeros autores e aplicações musicais, partiremos das teorizações e pensamentos de alguns autores - no geral, compositores - para formular uma síntese sobre o gesto instrumental e, mais genericamente, o gesto musical (obviamente, circunscrito

7 No original: "Autre chose encore me rendait cette idée particulièrement attrayante, c'est l'intérêt que présente pour le spectateur la visibilité de ces instrumentistes ayant chacun à jouer son rôle concertant. Car j'ai toujours eu un horreur d'écouter la musique les yeux fermés, sans une part active de l'oeil. La vue du geste et du mouvement des différentes parties du corps qui la produisent est une nécessité essentielle pour la saisir dans toute son ampleur". 
ao âmbito de nossos propósitos), para posteriormente evocá-los no que se referirá às distorções perpetradas pelos meios eletroacústicos.

O "gestual”, para Luciano Berio, não corresponde a um movimento espontâneo realizado intuitivamente com a pretensão de inaugurar movimentos novos, mas revela antes uma carga histórica, um legado cultural repertoriado de ações humanas que vinculam um sentido a determinados movimentos. Desde questões mais específicas como o repertório e a idiomática de um instrumento musical, até referências folclóricas ou inferidas de determinados estilos musicais ou mesmo ritos, a historicidade habita o gesto de modo inexorável; o gesto se consolida pelos rastros da ação humana e confere a estas ações certos significados que se associam a elas: "o gesto da escritura é, também, o traço visível da língua que falamos" (Berio, 2013 [2000, 1963], p.472). ${ }^{8}$ O "gesto da sala de concerto", por exemplo, traria inúmeras implicações e demandas sociais, uma expectativa com relação a certos protocolos, não no sentido do que deve ser um concerto, mas de como o que o concerto sempre foi contamina a expectativa dos presentes em relação ao que ocorre. ${ }^{9}$

É curioso como esta acepção de gesto para Berio se aproxima da chamada teoria da ação na filosofia, que demonstra haver um saldo quando se subtrai de uma ação seu movimento corporal, mostra "o que resta quando se subtrai do fato de que você levanta seu braço o fato de que seu braço se ergue" (Danto, 2005, p.38). ${ }^{10}$ São preci-

8 No original: "Il gesto della scrittura è, anche, la traccia visibile della lingua che parliamo".

9 "Os gestos da sala de concerto e do museu, por exemplo, tendem a se imporem como um parâmetro expressivo por vezes indiferente à obra, tornando-se, em alguns casos, até mesmo mais significativos que ela" (Berio, 2013 [1963], p.32. No original: "I gesti della sala da concerto e del museo, per esempio, tendono a imporsi come parametro espressivo talvolta indifferente all'opera e, in qualche caso, addirittura più significante di questa)".

10 Arthur Danto analisa, no contexto, seis afrescos de Giotto da Cappella degli Scrovegni de Pádua, em uma sequência narrativa em que a figura de Cristo mantém a posição invariante de braço levantado que, apesar de mais associada à bênção, adquire inclusive conotações de censura e admoestação, como no caso da discussão com os anciãos. Danto ressalta ainda a intenção e o contexto como elementos essenciais em obras como A fonte de Marcel Duchamp; elementos 
samente a intenção e o contexto que conferem a determinados atos características únicas, indo além desta carga histórica alocada a determinadas ações: não é só a articulação corporal ou um som vocal como um suspiro que trazem significação por si, mas a intenção e a contextualização é que conferem uma pregnância particular a eles, os imbuem de significados específicos. Mas esta carga histórica e cultural certamente afeta a caracterização e aquisição de significado em um gesto, mesmo considerando contextos muito distintos.

Com efeito, Berio afirma que, em especial na música vocal, grandemente carregada por um arsenal de aquisições culturais, torna-se difícil restringir a elaboração musical a parâmetros distintos e isolados, como a nota ou o ritmo: "A música vocal [...] pode mostrar a futilidade de qualquer tentativa de desenvolver um sistema baseado sobre um único nível de articulação: o nível das notas, por exemplo, serializadas ou não" (Berio, 2013 [1967], p.60). ${ }^{11}$ É esta intenção também que diferencia o gesto da "gesticulação", do tique ou do espasmo, mostrando uma relação direta com o que disse Stravinsky na citação que finaliza a seção anterior: para o compositor russo, o gesto também se diferencia de uma gesticulação despropositada e involuntária, mas refere-se precisamente à execução instrumental; ou seja, o gesto para Stravinsky é fortemente calcado no gesto instrumental, na ação do intérprete e em todas as conotações sedimentadas culturalmente e associadas a essa ação.

Este viés da carga cultural de um gesto pode explicar certa "estranheza" que eventualmente sentimos quando diante de uma deformação, um desvio de rumo de um gesto instrumental qualquer praticado com recursos eletroacústicos: o prolongar do decaimento "natural" e esperado de uma nota tocada ao piano, uma modificação

que a diferenciam do objeto comum urinol, obviamente idêntico porém relegado "a uma categoria ontologicamente degradada". Em alta sintonia, Berio faz referência, no mesmo texto já citado (Berio, 2013 [1963]), aos objets trouvés dadaístas para referir-se às relações do gesto com seu contexto.

11 No original: "La musica vocale [...] può mostrare la futilità di qualsiasi tentativo di sviluppare un sistema basato su un solo livello di articolazione: il livello delle note, per esempio, serializzate o no". 
nas intensidades de determinadas frequências do espectro de um violino e mesmo um deslocamento espaço-temporal via delays de um ataque percussivo podem causar um estranhamento entre o que se ouve ante o que se esperava ouvir pela ação instrumental. Radicalizam-se, ainda, possíveis transformações entre o que se vê e o que se ouve em situação de performance.

Isolando um desses sons transfigurados, pensando-o como um gesto, é certamente possível que, por mais que ele sofra alterações de rumo pelos meios eletroacústicos, ele mantenha uma trajetória energética que nos pareça musicalmente "fluida" e "aceitável". Mas enquanto gesto instrumental, ainda mais quando estamos diante da presença do performer, de seu instrumento, tendemos a notar mesmo assim uma distorção.

Poderíamos então arriscar a dizer neste ponto, no caso da música eletroacústica mista, que o gesto instrumental pode ser distorcido, como uma imagem de um objeto que se deforma diante de um espelho curvo. Mas isto não bastaria, já que sem os meios eletroacústicos também seria possível vislumbrar uma deformação no gesto instrumental, entendido como a própria sonoridade de um instrumento como o piano em uma composição para piano preparado, por exemplo. É aí que entram as particularidades das transfigurações e transformações somente possíveis com recursos eletroacústicos, com toda uma "história" de técnicas, procedimentos e experiências que marcam a identidade do meio, do ambiente eletroacústico: seu gesto. Além disso, é fundamental notar que estas transformações e transfigurações são capazes de atingir um nível extremamente radical, como vimos com François Bayle, possibilitando levar o som instrumental a situações virtualmente muito distantes.

Ouvindo uma das Sonatas para piano preparado de Cage (194648) e comparando-a, por exemplo, com Microphone bien tempéré (1950), de Pierre Henry (à parte considerações de ordem estética), realizada igualmente com sons obtidos em um piano preparado, notam-se claramente nesta última procedimentos composicionais vinculados às técnicas de manipulação do som em estúdio como inversão, estiramento, montagem etc. 
Em um outro contexto, Luciano Berio, já em 1959, analisa a diferença essencial que o meio eletroacústico proporcionou para a realização de Thema (Omaggio a Joyce), de 1958. A composição parte da leitura gravada do início do capítulo XI de Ulysses, de James Joyce; neste trecho, o compositor italiano identifica os mais típicos artifícios da execução instrumental:

trillo, appoggiatura, martellato, portamento, glissando. Entretanto, tais alusões certamente possuem apenas um significado relativo se comparadas com as possibilidades de análise, de decomposição e de síntese que nos oferecem os meios eletrônicos. [...] Conquanto sejam legítimas na medida em que permanecem fiéis às intenções de Joyce, tais considerações musicais baseadas simplesmente na presença de tais artifícios permaneceriam de toda forma limitadas ao campo da onomatopeia (que, com efeito, representam o estágio mais primitivo da expressão musical espontânea), ao que a língua inglesa se presta particularmente bem. (Berio, 1959 in Menezes, 2009 [1996], p.123)

É evidente que a escritura instrumental foi profundamente modificada de 1959 (época desse texto de Berio) para cá, incorporando muitos dos artifícios antes só pensáveis com recursos eletroacústicos. Mas, especialmente para os casos observados neste estudo do repertório da música mista, veremos que a diferença essencial entre os dois meios tende a permanecer.

À parte as inúmeras referências e acepções que o termo gesto adquire no campo musical, outra que nos interessa aqui é sua noção enquanto trajetória energética do corpo sonoro, ${ }^{12}$ caracterizadora de uma unidade singularizada e formadora de sentido no contexto musical. Em uma analogia com o campo visual, o gesto poderia remeter

12 O termo espectro-morfologia, criado por Dennis Smalley (1986, p.61-93), também abarca esta ideia: refere-se, de maneira muito geral, à caracterização dos objetos sonoros a partir de dois enfoques constantemente intercambiáveis da escuta: um em nível macroscópico, relativo ao envelope dinâmico (contornos) de um som; outro em nível microscópico, relativo às constituições espectrais. 
a um traço - acumulação energética - que se destaca de um fundo, como pode ser visto no quadro Ad parnassum (1932), de Paul Klee.

Da perspectiva do interior do som, portanto, o gesto pode ainda ser observado em ações cujo encaminhamento energético é conhecido, desde um movimento mais próximo a nós como o esforço envolvido e o resultado esperado para a realização de um sopro, a movimentos relacionados a máquinas que desenrolam trajetórias energéticas próprias, sem necessariamente ter relações diretas com ações humanas. De maneira semelhante, movimentos de fenômenos naturais como a chuva ou as ondas do mar sedimentam caminhos conhecidos para determinadas ações.

\section{O gesto nos materiais da música eletroacústica mista}

O gesto é essencialmente uma articulação do continuum.

Trevor Wishart

Considerando então o gesto como trajetória energética (que para um objeto ou evento sonoro pode remeter ao seu contorno global), o conceito será adotado como um elemento importante para a análise musical na segunda parte do trabalho. Com efeito, poderemos observar, do ponto de vista de trajetórias energéticas, tanto materiais provenientes de campos de alturas definidas, como uma melodia ou um ataque que ressoa longamente de um aglomerado harmônico no temperamento, quanto objetos sonoros conformados no continuum, que não passam necessariamente por parametrizações ou etapas discretas para se constituírem. ${ }^{13}$

13 Sobre a incorporação do caráter constitutivo dos espectros sonoros como conquista do material musical a partir da música eletroacústica, ver Menezes, 2009 [1996], p.17-50. 
O uso progressivo de procedimentos eletrônicos na composição e análise musicais consolidou modelos baseados na constituição e evolução dos espectros, "modelos do som" por assim dizer, extrapolando de vez o universo da música instrumental para além de modelos discretos, baseados na nota ou em valores rítmicos. Um modelo discreto de um espaço harmônico, em oposição ao continuum, advém dos pontos fixos estabelecidos como parte de uma escala graduada como o temperamento. ${ }^{14}$

Com vistas ao continuum sonoro, na chamada música eletroacústica mista há momentos de grande fusão e outros de maior segregação entre as dimensões instrumental e eletroacústica, e, especialmente nos casos de fusão, podemos agregá-las sob o viés da espectro-morfologia, seus contornos ou caracterizações espectrais. $\mathrm{Na}$ análise de Parcours de l'Entité, em diversos momentos a escrita (notação) estará ausente em detrimento de uma visão de escritura que contemple ambas as esferas do material de acordo com um modelo do som. Considerando os múltiplos focos de atenção possíveis por meio dos diversos estratos que o universo eletroacústico abre à percepção, surge um tema que nos será bastante útil para embasar a descrição dos materiais utilizados em Parcours..., qual seja: a dialética entre gesto e textura mencionada por Smalley. ${ }^{15}$

14 O termo "discreto" foi adotado para traduzir lattice, muito utilizado por Trevor Wishart para designar sistemas de organização musical com base em parâmetros discretos, finitos, como o temperamento para as alturas ou ritmos aditivos no caso das durações. Segue uma acepção próxima de "pontual”, com graus fixos. "Na música que lida essencialmente com o continuum (ao invés de uma estrutura discreta), o gesto estrutural torna-se o principal foco do esforço de organização" (Wishart, 1996, tradução livre).

15 O gesto sugere contornos definidos, enquanto a textura faz referência ao comportamento e à distribuição da energia interna de um som, demandando da escuta maior atenção a detalhes constitutivos. Estes dois elementos reforçarão a dualidade de perspectivas que Smalley apresenta para a escuta: "Quanto mais o gesto é alongado no tempo, mais o ouvido é direcionado a um foco textural" (Smalley, 1986, tradução livre). Mais uma vez, a referência visual é interessante: o já mencionado quadro de Klee serve como referência para este claro contraste entre o gesto e a textura nesta acepção. 
Frequentemente, os elementos que constituem os espectros sonoros (enfoque microscópico da escuta) farão referência a aspectos da textura, enquanto os contornos dos objetos sonoros (enfoque macroscópico) farão referência a aspectos gestuais. ${ }^{16}$ Em muitos momentos, porém, haverá características morfológicas que mesclam o enfoque gestual às suas extensões formativas do conteúdo espectral, resultado dos múltiplos níveis de funções estruturais existentes. Com efeito, há contextos mais gestuais e outros mais texturais, embora em geral trate-se de perspectivas complementares.

$\mathrm{E}$ aqui introduzimos nosso primeiro exemplo sonoro, que será retomado ainda outras vezes por ilustrar diversos aspectos caros ao tema da anamorfose: o momento inicial de Parcours de l'Entité, um som gravado proveniente do ataque percussivo em uma bigorna. Ao afastarmo-nos do transiente de ataque, não são casuais as transformações que o compositor realiza em estúdio no transiente de sustentação, prolongado temporalmente e, portanto, deslocado auditivamente do impacto percussivo (gesto) à textura que o forma. Há ainda uma expectativa "natural" para o decaimento deste som, mas o glissando e o batimento que o transfiguram subvertem o arquétipo ataque-ressonância, surpreendem-nos com uma "mudança de rumo", rompem a expectativa de um decaimento "natural" após o ataque. Quando a terminação de um determinado som sofre desvios de direcionamento espectral e dinâmico, há uma espécie de "modulação morfológica", o que Smalley denomina correspondência. Estabelece-se, pois, já no início da peça, uma interferência do universo eletroacústico para surpreender as expectativas do ouvinte em relação ao percurso "natural" do gesto instrumental. Conforme

16 Gérard Grisey (2008 [1980], p.69) também aborda este problema no texto "Tempus ex machina" do ponto de vista do tempo, dizendo que "pela aceleração, o presente é adensado, [...] o ouvinte é literalmente propulsionado ao que não conhece ainda [...] Por outro lado, a desaceleração de durações provoca uma espécie de expectativa no vazio do presente". No original: "Par l'accélération, le présent est densifié [...] et l'auditeur est littéralement propulsé vers ce qu'il ne connaît pas encore [...] Au contraire, le ralentissement provoque une sorte d'attente dans le vide du présent". 
ainda será visto em mais detalhes, esta transfiguração corresponde a uma anamorfose no interior do som e encerra uma ilusão, uma deformação.

Exemplo sonoro 1 - Ataque inicial de Parcours de l'Entitée $e^{17}$

\section{A figura}

O gesto pode, certamente, ser pensado como uma unidade estrutural não necessariamente discreta ao longo da composição - para citar exemplos que serão mencionados na análise de Parcours..., os elementos "sopro" e "ataque metálico", qualificados como elementos estruturais. Nesse sentido, é oportuno mencionar o conceito de figura - circunscrito a nossos propósitos -, que atenta justamente para este aspecto relacional, em que predominam as determinações do contexto em relação à carga histórica de um gesto. Para Brian Ferneyhough, o gesto estaria por demais carregado de sua própria historicidade baseada na ação humana, de uma visão "holística" enquanto material composicional. O gesto passaria, assim, pela necessidade de ser recontextualizado a partir da figura, valorizando seus aspectos estruturais enquanto elemento passível de ser recombinado: ${ }^{18}$

É imperativo que a ideologia do gesto holístico seja destronada em favor de uma modelização que leve em conta os potenciais transformativos e energéticos dos subcomponentes que constituem o gesto. [...] Um gesto cujas características constitutivas - timbre, contorno melódico, nível dinâmico etc. - mostrem uma tendência a escapar de um contexto específico para então passarem a compreender radicais independentes de significação, livres para serem

17 Disponível em: <https://soundcloud.com/tiago-gati>.

18 Ver especialmente os artigos "Form-Figure-Style" (1982) e "Il tempo dela figura” (1984). 
recombinados, para "solidificarem" outras formas gestuais, pode, pela necessidade de uma outra nomenclatura, ser denominado figura. (Ferneyhough, 1995, p.26) ${ }^{19}$

A noção de figura pode, de toda maneira, auxiliar-nos a enfocar o gesto de fato enquanto unidade estrutural. A caracterização que faremos dos elementos musicais gestuais na análise de Parcours... ressaltará, para além de associações à ação humana (o "sopro", por exemplo), suas características internas relacionais. A figura ressalta a recontextualização do som, seu distanciamento da origem e reinserção enquanto elemento musical. Assim, como uma extensão para a dialética fundamental entre gesto e textura, a figura entraria em cena para valorizar a dimensão relacional dos elementos musicais. O gesto musical seria, deste ponto de vista do material, "a história da figura" (Menezes, 2011a).

Um exemplo prático sobre esta questão da figura reside na escuta de contornos não necessariamente dependente da escuta intervalar, permitindo aproximar em termos relacionais elementos cujos perfis se assemelhem, mas cujo conteúdo espectral seja até bastante distinto, mantendo, porém, certa similaridade na distribuição energética de seus subcomponentes. Nesses casos, passamos a comparar elementos que advém de contextos diferentes, erodindo sua origem referencial para valorizar o aspecto da figura. Nesse sentido, o conceito de figura emerge claramente em Colores (Phila: in Praesentia) (idem, 2000): a figura inicial no clarinete é reconhecida depois na percussão (figura final), valorizando a dimensão relacional, combinatória, tornando-se assim, pode-se dizer, um gesto (ver figuras 1 e 2 a seguir).

19 No original: "It is thus imperative that the ideology of the holistic gesture be dethroned in favor of a type of patterning which takes greater account of the transformative and energic potential of the subcomponents of which the gesture is composed. [...] A gesture whose component defining features - timbre, pitch contour, dynamics level etc. - display a tendency towards escaping from that specific context in order to become independently signifying radicals, free to recombine, to 'solidify' into further gestural forms may, for want of other nomenclature, be termed a figure". 
De toda maneira, o som pode ser pensado do ponto de vista espectro-morfológico, ou seja, em termos de seu contorno e com uma dada estrutura interna, estrutura esta mais ou menos perceptível em suas distinções discretas. Ouvir o modelo criado por meio de cada figura é extremamente eficaz enquanto unidade, independentemente do reconhecimento dos intervalos constitutivos. No caso da obra em questão, o modelo que surge inicialmente provém de um instrumento particular, o clarinete - é "melódico", discreto e constitui uma figura peculiar: sua terminação é um trilo no registro médio-grave, caracterizando-o enquanto elemento fortemente "gestual", no sentido mais comum do termo:

Figura 1 - Último sistema da página 2 de Colores.

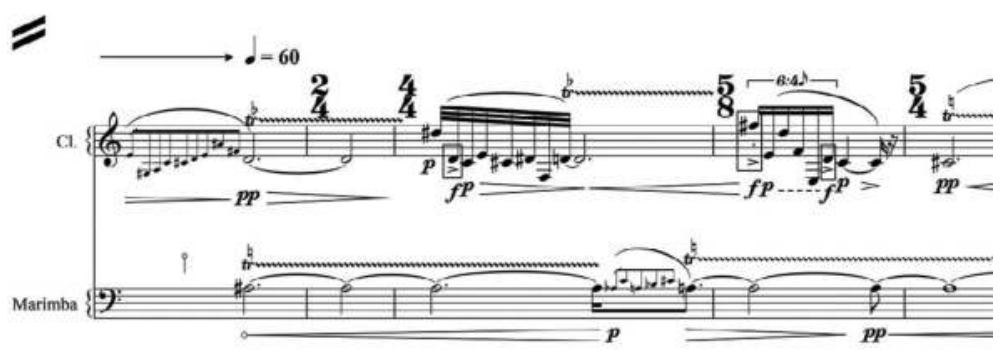

Figura característica no clarinete.

Fonte: Menezes (2000, p.2)

Na página 11 da partitura, esta figura é reconstituída de maneira inusitada, porém bastante próxima auditivamente do original em termos de seu contorno: o compositor a replica nos instrumentos de percussão, e embora não haja mais alturas definidas o contorno é perceptível por sua proximidade e distribuição energética com a primeira: 
Figura 2-Colores, página 11.

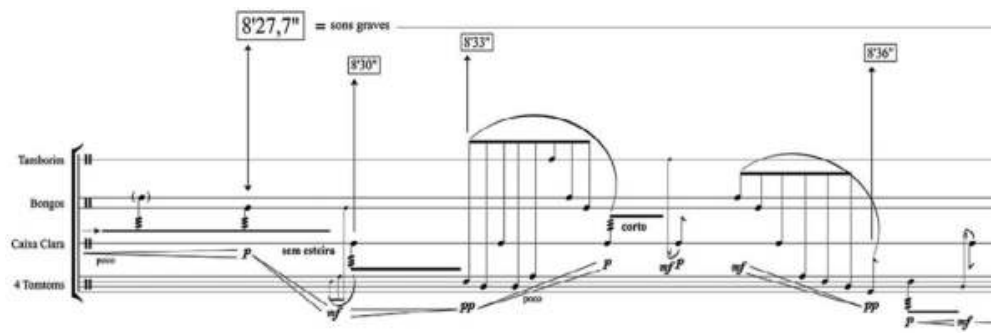

Figuras a partir de 8'30" seguindo o modelo estabelecido inicialmente no clarinete.

Fonte: Menezes (2000, p.11)

Ouçamos agora os dois trechos em sequência:

Exemplo sonoro 2 - Trecho de Colores (Phila: in Praesentia) (Menezes, 2000) $)^{20}$

É certo que, conforme o caso, mudamos constantemente o foco da escuta, e estas delimitações do gesto, da textura e da figura mostram-se altamente intercambiáveis; como diz Silvio Ferraz (1998, p.34): "a textura, a figura e o gesto não são unidades estanques, relacionáveis apenas hierarquicamente segundo algum critério geral de importância. Vistas como territórios da escuta, elas são contemporâneas e coexistentes se envolvendo umas às outras". No contexto da interação instrumento-eletroacústica, há momentos em Parcours de l'Entité, por exemplo, como no início da segunda seção, em que os perfis figurais (característica preponderantemente gestual) apresentados na esfera eletroacústica adquirem uma "rugosidade" (característica textural) que havia sido sugerida pelos trêmulos e ataques fortes na flauta, criando então um modelo espectro-morfológico passível de ser reelaborado, proliferado e recombinado. ${ }^{21}$

20 Disponível em: <https://soundcloud.com/tiago-gati>.

21 Nos casos em que é preponderantemente a textura que mostra uma influência do modelo espectral do instrumento ao corpo eletroacústico, ou vice-versa, será preferível o termo transferência espectral para fazer menção à recombinação de características texturais.Vários casos transicionais na interação entre 
À parte estas considerações acerca da figura, preferi concentrar esforços - especialmente pensando na segunda parte do livro - na dialética gesto-textura, avaliando que o gesto encerra tanto as conotações culturais quanto as características de contornos sonoros, suas qualidades espectrais, agrupando assim unidades que nos permitirão pensar mais globalmente o material na composição, seja ele advindo da esfera eletroacústica ou da esfera instrumental.

\section{O continuum ${ }^{22}$}

O continuum sonoro passará, aqui, a ser analisado por meio das conexões e contrastes entre gesto e textura, constituindo o terreno no qual buscaremos mapear anamorfoses na interação dos meios instrumentais com os eletroacústicos. A noção de continuum conforme Pierre Boulez nos será particularmente útil para melhor situar, em um primeiro momento, a questão do espaço discreto: na segunda parte de A Música hoje, ainda que construa sua argumentação com referência a modelos estritamente discretos com o uso da série e com absoluta preponderância da altura como parâmetro, as morfologias sonoras resultantes podem se distanciar da percepção de pontos discretos (alturas definidas) na evolução das estruturas musicais: um exemplo típico seria um som ruidoso proveniente de um cluster ao piano, que embora seja constituído de unidades discretas resulta em uma saturação e acumulação de alturas. O músico francês realça que no continuum se instaura uma alternância entre espaço liso e estriado, que reafirma a fluidez com que a percepção pode transitar entre

instrumentos e meios eletroacústicos serão abordados posteriormente a partir do conceito de transferências espectrais (Menezes, 2006 [2001], p.385).

22 A partir deste ponto, começarei a traçar paralelos entre conceitos particularmente úteis para a análise de Parcours de l'Entité, que será feita na segunda parte do trabalho. Tendo em vista a forte produção teórica de Flo Menezes, que frequentemente desenvolve conceitos e os relaciona às suas obras musicais, farei uma incursão sobre alguns deles mais diretamente envolvidos na análise de Parcours..., eventualmente relacionando-os com outros autores. 
movimentações mais ou menos definidas no espectro. O perfil apresenta-se, neste contexto, no limiar do tecido composto pelos contornos bem definidos e pelas distribuições estatísticas do material.

Chegou, ao que parece, o momento de prospectar espaços variáveis, com definições móveis - tendo oportunidade de evoluir (por mutação ou transformação progressiva) no curso mesmo de uma obra. Esta variabilidade dos espaços está ligada, por um lado, à complexidade e à densidade da estrutura interna, o encadeamento, a distribuição ou a superposição dos fenômenos sonoros, que impedem - por dispersão ou saturação - a percepção de intervalos muito diferenciados; por outro lado, ao tempo geral que rege a velocidade de desenvolvimento das figuras, devendo o ouvido prender-se algum tempo à percepção dos intervalos para ser capaz de apreciá-los; ligada, enfim, à relação proporcional dos intervalos entre si, sendo uma fina modificação de uma quantidade a outra ainda mais sensível porquanto opera numa ordem de grandeza restrita [...] Acentuamos a variabilidade do espaço, a partir de definições móveis, temperadas ou não. É preciso voltar com mais detalhes a este ponto extremamente importante, pois ele nos leva, por um lado, à noção de continuum, por outro lado, à definição qualitativa do espaço sonoro considerado, por ora, sob o ângulo das alturas exclusivamente. Parece-me primordial definir, antes de mais nada, o continuum. Não é, certamente, o trajeto contínuo "efetuado" de um ponto a outro do espaço (trajeto sucessivo ou soma instantânea). O continuum se manifesta pela possibilidade de cortar o espaço segundo certas leis; [...] o espaço das frequências pode sofrer duas espécies de cortes: uma, definida por um padrão, renovar-se-á regularmente, a outra, não precisa, não determinada, mais exatamente, intervirá livre e irregularmente. Para estimar um intervalo, o temperamento - escolha do padrão - será uma ajuda preciosa, ele "estriará" em suma, a superfície, o espaço sonoro, e dará à percepção - mesmo longe da total consciência - os meios de se orientar utilmente; no caso contrário, quando o corte for livre de se efetuar onde se quiser, o ouvido perderá toda referência e todo conhecimento absoluto dos intervalos, 
comparável ao olho que deve estimar distâncias sobre uma superfície idealmente lisa. [...] é suficiente dispor, num espaço liso, intervalos que mantenham proporções sensivelmente iguais, para que o ouvido os conduza a um espaço estriado; da mesma maneira, se empregarmos intervalos muito dessemelhantes em proporções, num espaço estriado, a percepção os destacará de seu temperamento, para instalá-los num espaço liso [...]. Com estas distinções, cuja sutileza, longe de ser gratuita, é baseada na própria realidade, estamos bastante longe do continuum definido em seu único limite de percurso contínuo ou de integração total. [...] Os espaços lisos, quanto a eles, não se podem classificar senão de uma maneira mais geral, isto é, pela distribuição estatística das frequências que aí se encontram. (Boulez, 2002 [1963], p.83-6)

A ambiguidade entre os espaços liso e estriado de Boulez nos traz uma perspectiva interessante por meio da noção de perfil, pois prevê, de certo modo, o distanciamento possível a que pode ser submetida uma estrutura intervalar, construída no temperamento, ao extremo de ser absorvida no todo de um envelope dinâmico e diluir-se na textura, em um espaço liso. Além disso, na música eletroacústica mista, que permite transferências espectrais de uma dimensão a outra do material, e mesmo em exemplos exclusivamente "instrumentais", como foi visto em Colores..., o continuum pode abarcar a percepção de perfis cujos contornos se singularizem independentemente de um material discreto comum.

Um elemento de forte caráter "gestual" delimitado no continuum sonoro, que não seja, necessariamente, discreto, possuindo alta relevância estrutural, estará intrinsecamente ligado ao conceito de perfil melódico, estrutura mais percebida enquanto contorno do que propriamente por sua organização intervalar. Este conceito provará ser essencial para a análise de Parcours de l'Entité, uma vez que muitas das estruturas são elaboradas com base em procedimentos de cunho serial. Embora sejam de fundamental importância o reconhecimento intervalar e a preponderância de alguns intervalos, o perfil adquire também uma relevância na medida em que o compositor comprime 
e expande grupos de notas cujo contorno se mantém reconhecível, embora distorcido. $\mathrm{O}$ fundamento da noção de perfil é que ele não depende, necessariamente, da percepção de altura definida; ele adquire, pela unidade do seu contorno, uma potencialidade relacional, e quando variado ou repetido no amplo contexto da forma atinge função estrutural na composição.

Um exemplo intrigante, tomado de um contexto tonal, é o elemento cromático presente nos compassos 8 e 9 do primeiro movimento (Molto moderato) da última sonata para piano de Franz Schubert, D.960, em Si bemol maior. Este elemento é particularmente próximo à concepção de uma figura que constitui um gesto estruturante, já que seu conteúdo harmônico não o singulariza tanto auditivamente quanto seu contorno geral: trata-se de uma apojatura cromática seguida de um trilo no registro grave que resulta, auditivamente, mais em um elemento "gestual", de contorno, com pouca clareza do conteúdo harmônico por conta do registro gravíssimo do piano. Esta figura mostra-se estruturalmente importante não só por sua forte recorrência no primeiro movimento, mas também por situar-se em momentos de articulação formal.

O perfil melódico, conceito bastante explorado por Menezes, parte de uma complexa teia de outros conceitos para se definir e, pela importância que adquire na análise de Parcours..., será explorado aqui. Assim como sugerido anteriormente, a noção de perfil extrapola a necessidade de partir de um grupo de alturas definidas, e por esta razão Menezes (2004, p.127) constrói sua argumentação com base na percepção geral de altura dos objetos sonoros: "A percepção das alturas não é, de forma alguma, exclusiva dos sons periódicos. Com exceção, obviamente, do ruído branco [...], os demais ruídos e os sons complexos podem ser e são, de fato, percebidos também com uma determinada localização no campo das alturas".

A altura definida será, em tese, exclusiva dos sons periódicos, cuja relação de parciais segue uma proporção harmônica de números inteiros, da qual resulta, para a escuta, uma fundamental estável. Como não há de fato sons perfeitamente harmônicos, há variações próximas a este modelo que permitem manter a sensação 
de altura definida, mas alguns fatores podem afastar a referência de uma altura preponderante, como uma distribuição de parciais que se distancia da relação de números inteiros e uma distribuição de cunho estatístico das frequências no espectro (ou seja, com mínima concentração energética em uma determinada banda que resulte em uma percepção de altura preponderante).

Mesmo assim, a maior intensidade de certas bandas de frequência pode resultar, como comumente ocorre nos sons complexos (ou misturas, distribuição inarmônica de parciais), numa percepção global de altura, delimitada com menos estabilidade que no caso dos sons tônicos (periódicos). ${ }^{23}$ Menezes delimita, portanto, esta percepção de altura como uma "percepção localizada" (idem, ibidem, p.129), uma síntese que a escuta realiza, mais ou menos distante da fusão característica dos sons tônicos. A argumentação parte da definição de Pierre Schaeffer, que utilizava o termo "massa" para designar esta percepção de "localização no campo das alturas" tanto para os sons tônicos quanto para os sons complexos. ${ }^{24}$

Partindo da percepção de campos de alturas, que em uma escala graduada excluiria o ruído branco (dispersão máxima do espectro), distinguem-se duas situações possíveis para o comportamento temporal de um som: a realização de perfis, mudanças entre regiões distintas de alturas (definidas ou não), ou uma "estaticidade" do espectro em termos de altura e sem a percepção de contornos definidos, havendo então, para a audição, um direcionamento eminentemente voltado às caracterizações de timbre. Neste ponto, nota-se a possibilidade de aproximação com a dialética gesto-textura do ponto

23 Em alguns casos, a percepção mantém clara e distintamente o reconhecimento de uma "fundamental", ainda assim associável a uma "nota musical". No início de Parcours..., por exemplo, ouve-se claramente o Lá bemol preponderante em meio ao espectro inarmônico do ataque metálico.

24 Filtragens sucessivas passa-banda de um ruído branco delimitam perfis, o que não ocorre com um som tônico ou um som complexo. Para estes últimos, ocorre apenas a variação de coloração que Menezes designará por modulação de timbre. Esta característica que permanece inalterada na percepção de altura de um objeto, este algo que não muda no procedimento de filtragem, Schaeffer (1996 [1967], p.20) denomina massa. 
de vista da percepção de um som: se não há perfil, elemento mais comumente associado a uma origem gestual, o foco da escuta tende à constituição espectral ou, de maneira geral, ao timbre. Para Menezes (ibidem, p.129-130), por meio de abordagens distintas para os sons tônicos e para os sons complexos e ruídos, a noção de timbre é repensada na sua oposição - por ora ainda não propriamente definida - ao perfil:

À fixidez ou estabilidade (relativa) da massa tônica ou complexa opõe-se a variabilidade ou instabilidade perceptível da massa variável (aquela que se modifica no decurso temporal de um som, seja ele tônico ou complexo) ou da massa aleatória (variação acentuada e extremamente acelerada em alturas, introduzindo-nos a uma escuta de tipo estatístico), cuja variabilidade frequencial (tanto da massa variável quanto da aleatória) dá lugar à percepção dos chamados perfis melódicos [...] em que efetivamente tem lugar a percepção de contornos ou perfis pela justaposição dos intervalos de calibres distintos - quando tratamos de variação em alturas dos sons tônicos ou das misturas. Mas quando falamos do alargamento ou estreitamento da banda de frequência de uma mistura ou de um ruído, não é adequado falarmos de um "perfil" de massa, já que, a rigor, nenhuma percepção de contorno tem aí lugar, mas antes uma percepção ligada a um adensamento ou diluição de uma massa sonora essencialmente estável no campo das alturas. Se Schaeffer entendia, no âmbito da contextura harmônica aperiódica (sons de altura indefinida, das misturas aos ruídos), por "perfil" de massa - como extensão de sua terminologia - tais alargamentos ou estreitamentos das misturas ou ruídos, preferimos falar contudo, então, de variação de espessura do espectro inarmônico.

Portanto, quando há mudança de uma localização no campo das alturas a outra, ou seja, quando se percebe a realização de um contorno delimitado no espaço harmônico (na distribuição frequencial do espectro), há perfil. Do contrário, há variação de espessura para os sons complexos e ruídos ou variação de timbre harmônico para os 
sons tônicos. É neste contexto que Menezes distingue a fusão tônica para os sons tônicos da massa complexa para os sons complexos e ruídos, reservando o termo massa apenas para os contextos que determinam uma escuta de tipo "difusa (sons complexos)" ou "estatística (ruídos)".

De forma a nomear a oposição mencionada anteriormente entre contorno e timbre, contrapõe-se ao conceito de perfil melódico (contorno) a modulação de timbre, quando não há, em um movimento sonoro, percepção de contorno em termos de localização no campo das alturas e o foco da escuta se volta mais à constituição espectral:

Caso a fusão tônica ou massa complexa varie em frequência, seja tal variação constituída por movimento contínuo (glissando) ou por movimento descontínuo (saltos ou intervalos) dizemos, com Schaeffer, que estamos defronte de perfis melódicos. No caso, entretanto, de uma variação de timbre harmônico da fusão tônica ou da espessura da massa complexa sem que haja variação frequencial da localização do objeto sonoro no campo das alturas - tendo-se no máximo, no caso da fusão tônica, uma variação de coloração do som de altura definida, variando sua densidade harmônica (composição espectral harmônica); e, no caso da massa complexa, uma variação de espessura da sua densidade interna (pelo alargamento ou estreitamento da massa) -, tem-se então uma modulação de timbre, conceito este que introduzimos aqui pela primeira vez. (idem, ibidem, p.131)

Assim, não importa se no transcorrer de um som seu percurso por diferentes regiões de alturas for contínuo ou por salto, ou mesmo se a estas regiões esteja associada uma percepção de altura definida ou não. Se há percepção clara de um contorno, há perfil. E este perfil poderá, segundo determinados critérios de composição, ser submetido a procedimentos relacionais para adquirir função estrutural em uma obra, contando com uma pregnância na reconhecibilidade auditiva, seu caráter de unidade e força atrativa para a escuta.

Quando não há percepção de contorno e o que se apreende da evolução de um som está relacionado à densidade espectral, em 
suma, ao foco textural, introduz-se o conceito de modulação de timbre. Vale aqui um comentário interessante: independentemente das possíveis relações de um objeto sonoro com outros, a escuta com enfoque textural tende a centrar-se na apreensão geral e interna de um mesmo objeto. O caráter de centrar a percepção nas constituições espectrais de um objeto único, isolado de seu aspecto relacional, traz à tona uma singularização que György Ligeti faz acerca do foco textural, que, além de poder abarcar aspectos advindos do comparativo espectral entre objetos distintos - por exemplo, quando duas texturas distintas entram em confronto direto e se contrapõem -, assume um papel dinamizador das formas enquanto elemento único. ${ }^{25}$

De maneira sintética, vejamos na figura seguinte um resumo da diferenciação proposta por Menezes entre o perfil melódico e a modulação de timbre. Uma condição necessária para haver modulação de timbre é a ausência da percepção de perfil; além disso, é preciso haver esta mudança gradual da qualidade do espectro, de seu timbre: "uma modulação de timbre [...] atenta a escuta imediatamente para o fato de o espectro em questão estar sendo metamorfoseado em sua 'coloração', em sua conformação global estatisticamente detectável pelo ouvido” (Menezes, 2004, p.131).

25 Sobre esse assunto, ver o artigo "La forme dans la musique nouvelle", presente na publicação francesa da coletânea de ensaios do compositor húngaro (Ligeti, 2001, p.147-62). 
Figura 3 - Quadro sintético que compara o perfil melódico com a modulação de timbre

Tipos de sons e percepção das alturas a eles associada

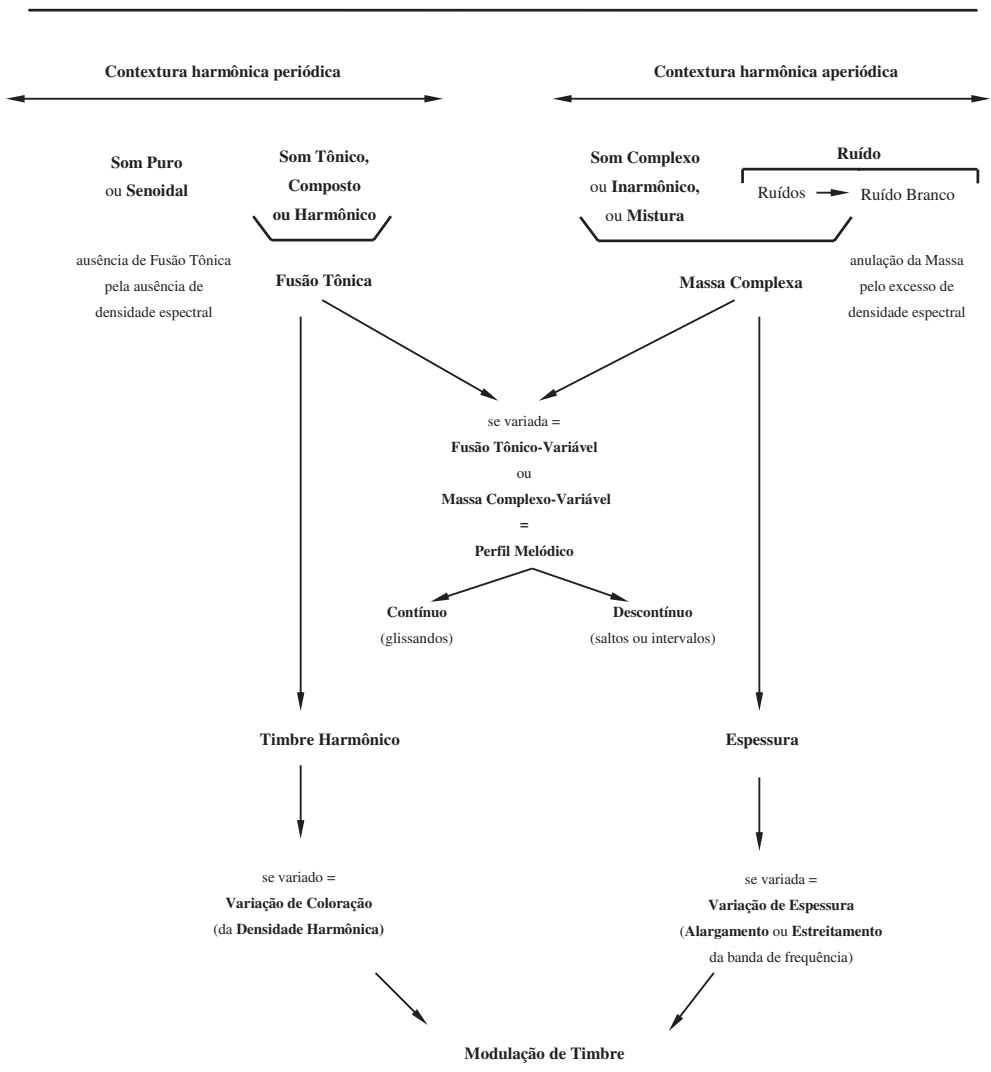

Fonte: Menezes (2004, p.132)

Além do perfil e da modulação de timbre, um outro conceito complementar trata de movimentos sonoros mais gerais, que não se limitam à observação restrita ao campo das alturas: a morfologia dinâmica (Wishart, 1996, p.94), que diz respeito a movimentos genéricos no decurso de um som que apresentem, simultaneamente, variações significativas no campo de alturas (perfil melódico) e no timbre (modulação de timbre). Para objetos sonoros que apresentem variações espectrais em um campo fixo de alturas (precisamente o 
conceito de modulação de timbre para Menezes), Wishart menciona a noção de glissamento espectral, ${ }^{26}$ de Robert Erickson, mas em seguida define que a morfologia dinâmica apresenta um aspecto mais geral, que abarca também a variação no campo das alturas:

Em seu livro Sound Structures in Music (1975), Robert Erickson discute o conceito de glissamento espectral, essencialmente a evolução de características espectrais em um plano fixo de altura, enquanto Pierre Schaeffer (1966) discute o conceito de flutuação, ${ }^{27}$ variações sutis em dinâmica e envelope espectral de um som de massa constante. Aqui ambos serão tratados como casos especiais de morfologia dinâmica. Um som mais típico será um cujo espectro, níveis dinâmicos e campos de alturas variam no continuum com o curso deste som. (Wishart, 1996, p.94, tradução livre)

Um exemplo sonoro presente em seu livro On sonic art ilustra a morfologia dinâmica: usando o programa computacional Chant, do Institut de Recherche et Coordination Acoustique/Musique (Ircam), de Paris, Wishart transforma de maneira gradual e fluida um som vocal sibilante em sons de pássaros por meio da "combinação de uma aceleração dos impulsos individuais e do alargamento das estruturas formânticas envolvidas" (idem, ibidem, p.95). Este exemplo de morfologia dinâmica pode ser comparado à abertura de Parcours de l'Entité (exemplo sonoro 1): trata-se de uma espécie de metamorfose sonora, que, no entanto, passa por um fase transitória que se mostra ambígua, que converge características espectrais de um antes e um depois na evolução de um som, uma anamorfose, para constituir, de forma global, um único objeto, uma morfologia dinâmica.

Por meio da análise de Parcours... será possível elencar alguns modos de interação instrumental e eletroacústica que permitem, de uma maneira ou de outra, conferir unidade à composição do ponto de vista de contemplar as naturezas distintas do material, como:

26 Tradução livre do termo spectral glide.

27 Tradução de Flo Menezes para allure. 
46 TIAGO GATI

polarizações harmônicas; "imitações" ou transferências espectrais dentro do espaço frequencial; ou o uso de métodos típicos da escritura instrumental para a elaboração eletroacústica, em uma espécie de "transferência de escritura", o que Menezes (1998) denomina escritura latente. 


\section{2 \\ ANAMORFOSES NA MÚSICA ELETROACÚSTICA MISTA}

\section{Tempi reali, tempo virtuale: ${ }^{1}$ em direção a uma virtualização dos meios instrumentais}

Um aspecto bastante peculiar na performance da música eletroacústica mista reside nas distorções de cunho audiovisual observadas no gesto instrumental. Estas deformações atuam, por um lado, no olhar, nas relações descontínuas entre a ação do músico e o que de fato se ouve a partir das transfigurações do material, entrando em conflito com a presença física do performer em cena, e, por outro lado, na escuta propriamente, já que entram em jogo objetos sonoros cujas causas não se conhecem e que podem estar menos ligados à ação humana advinda do gesto instrumental, mais "maquinizados" pela sua relação com processos referentes à ação de outras máquinas adaptadas ao fazer musical.

Esta "deformação" do gesto instrumental, sua anamorfose, pode ser observada no seguinte Estudo anamórfico para percussão múltipla, em que o papel das interferências eletroacústicas realizadas ao vivo é instaurar pequenos "curtos-circuitos", distorções mais ou menos

1 Referência à obra mista Contexture III: Tempi reale, Tempo virtuale (Flo Menezes, 1990), que usaremos a título de exemplo a seguir. 
sutis no gesto do performer a partir da gravação em tempo real de trechos tocados e sua posterior reprodução transformada em diferentes momentos.

Exemplo sonoro 3 - Estudo anamórfico para percussão múltipla $(\text { Gati, 2014) })^{2}$

Como já foi mencionado, a escritura instrumental e a eletroacústica "contaminam-se" uma à outra, provocam-se, desafiam-se. Somente para mencionar o fator do espaço, pode-se recorrer às experiências cruciais a partir dos anos 1950 em um desejo de levar o esfacelamento espacial proporcionado pelos meios eletroacústicos ao campo instrumental: Gruppen (1955-57) de Stockhausen, para três grupos orquestrais; ${ }^{3}$ as já citadas Rimes pour Différentes Sources Sonores de Pousseur e Poésie pour Pouvoir de Boulez, ambas com fita magnética, e Allelujah 1 (1955-56) de Berio, para seis grupos instrumentais, todas envolvendo um enorme reflexo do que representou o esfacelamento do espaço trazido pela experiência em estúdio. ${ }^{4}$

Desde o final da década de 1940, quando efetivamente se tem como dada a origem da música eletroacústica, o universo musical é inundado por uma vasta gama de sons e processamentos sonoros possíveis, refletindo também uma significativa tendência de mudança na escritura instrumental: como consequência, pode-se pensar nas análises de espectros sonoros para definir espaços harmônicos por Gerard Grisey ${ }^{5}$; ou nos arquétipos sonoros definidos por Helmut Lachenmann,que parte também de um processo analítico (definição de arquétipos de ataque-ressonância, trama sonora, flutuação etc.)

2 Disponível em: < https://soundcloud.com/tiago-gati>.

3 Embora não contenha uma contraparte eletroacústica, a obra é fortemente influenciada pelas experiências contemporâneas em estúdio de Stockhausen.

4 Mais detalhes em Menezes (1998, p.15-6).

5 "A eletrônica e a análise do som transformaram radicalmente, a partir dos anos 1970, minha escritura instrumental [...] As formas e os sons que imagino seriam sem dúvida impensáveis sem a influência revigorante da eletrônica" (Grisey, 2008 [1985], p.175, tradução livre). 
para sintetizá-los em modelos escritos para corpos instrumentais, acabando por definir a "música concreta instrumental". ${ }^{6}$

Hoje, já após um substancial avanço no sentido dos recursos eletroacústicos terem mudado a forma de escrever ou mesmo fazer música instrumental, o que nos interessa particularmente são as expansões possíveis e peculiares que o aparato eletroacústico, com toda uma história repertoriada de processos, técnicas e realizações musicais, promove no corpo instrumental.

A partir do momento em que são introduzidos elementos e processos intermediários de produção sonora na execução direta instrumental, surge uma problemática fundamental com uma mudança significativa no gesto instrumental; promovemos, em certa medida, uma virtualização do instrumento, abrimos a possibilidade desse instrumento adquirir características muito particulares de um "ambiente acusmático", pode-se dizer. Estas características podem surgir no âmbito da execução instrumental em si - possibilita-se, por exemplo, uma "maquinação"7 no gesto musical, incorporando elementos próprios e somente possíveis de serem realizados pela máquina eletroacústica -; em transformações espectrais; e em realocações espaço-temporais - o som produzido pode ser levado, virtualmente, a qualquer lugar ou tempo ${ }^{8}$ em uma performance, desvinculando-se potencialmente do gesto instrumental.

6 O termo "música concreta instrumental", utilizado pelo compositor alemão, refere-se à busca por uma desfamiliarização da técnica instrumental, pela utilização não usual de instrumentos sedimentados historicamente, em meio ao contexto da música de concerto.

7 Pensa-se aqui em um exemplo específico que trata esta questão: Machination, obra mista de George Aperghis para três vozes femininas, que, muito enfaticamente, promove quebras no fluxo musical e oral via recursos eletroacústicos, "maquinizando" a própria voz.

8 Além do caso da difusão de sons pré-elaborados em estúdio, é possível transformar ao vivo os sons provenientes dos instrumentos de diversas maneiras: alterações de duração, altura ou outras modificações espectrais, captação e reprodução de materiais tocados pelo intérprete em momentos posteriores (pelo uso de delays ou da gravação e reprodução de um buffer) e, finalmente, uma reconfiguração do espaço da performance, pelas possíveis alterações e 
Na música eletroacústica mista, em que coexistem universos sonoros eletrônicos e corpos instrumentais fisicamente presentes, surge uma problemática essencial de ambiguidades via um jogo ilusório entre referencialidade a um objeto "real" e não referencialidade, entre o que provém do intérprete em cena e o que é difundido por alto-falantes, se há transformações ao vivo de elementos espaciais ou morfológicos do corpo instrumental ou se são ouvidas "estruturas pré-elaboradas em estúdio, constituídas a partir dos próprios instrumentos ou a estes timbricamente correlatas" (Menezes, 1998).

E é esta problemática da música mista, ligada às deformações até certos limites de uma "realidade" instrumental em função de sua potencial virtualização pelos recursos eletroacústicos, que passarei a denominar anamorfose.

A esfera eletroacústica abre, portanto, um amplo e peculiar campo de possibilidades à música instrumental, que mapearei com alguns exemplos práticos a seguir. É preciso dizer que estes exemplos serão importantes para ilustrar situações mais comuns ligadas às anamorfoses na música mista, que investigarei mais a fundo daqui em diante; não houve, certamente, qualquer pretensão de esgotar as transformações possíveis na interação com os meios eletroacústicos. Os exemplos podem ainda conter, eventualmente, mais de uma característica além daquela à qual foi associado:

1) Alto controle na dinamização espacial dos sons, tanto no âmbito das trajetórias espaciais possíveis quanto na distinção de planos sonoros

Ouçamos inicialmente, para ilustrar esta interferência possível do dispositivo eletroacústico no tocante a um maior controle da distribuição de planos e profundidades sonoros no espaço, um trecho de Contexture III (Tempi reali, Tempo virtuale), para dois pianos e

manipulações das trajetórias e planos dos sons no espaço. Algumas destas transformações serão exemplificadas mais adiante. 
live-electronics, de Flo Menezes, em que se delineiam claramente distintos espaços de profundidades entre os pianos:

Exemplo sonoro 4 - Diferenciação de profundidades em Contexture III (Menezes, 1990) ${ }^{9}$

2) Transformações ou transfigurações ${ }^{10}$ espectrais em diversos níveis e com alto controle

O exemplo sonoro 1 volta a ser uma referência importante aqui, já que o ataque metálico sofre uma mudança de rumo em direção a um som "flautado": além da transfiguração que ocorre com seu decaimento, prolongado artificialmente, há ainda uma transformação com a inserção de reverberação e de um fenômeno de batimento pelo compositor, levando a esta qualidade de "som de flauta", sintetizando a presença dos dois universos instrumentais da peça (flautas e percussão metálica).

Em outro exemplo, desta vez voltado ao processamento eletrônico em tempo real, tomaremos um trecho de Nomoi, para violino e live-electronics (Gati, 2013), em que são exploradas estas possibilidades de transfiguração pelo prolongamento do som via ação de feedback e filtragens do sinal. Embora estejamos diante de uma redução

9 Disponível em: < https://soundcloud.com/tiago-gati>.

10 Adoto, em diversos momentos, a diferença entre transfiguração, que sugere modificação até certo limite de reconhecibilidade, mantendo a identidade, e transformação, que leva a um polo mais distante, caracterizando já um outro som, sem qualquer referência ao de origem. É precisamente nesses meandros que se instauram as anamorfoses, quando se impõe a condição de dúvida. Danto (2005, p.246-7) lança um argumento interessante acerca desta diferenciação: "uma escultura de Napoleão como imperador romano não se limita a representá-lo em trajes arcaicos [...]. Faz parte da estrutura de uma transfiguração metafórica que o objeto da metáfora mantenha sua identidade o tempo todo e seja reconhecido como tal. Trata-se, portanto, mais de uma transfiguração que de uma transformação: Napoleão não se converte em imperador romano; ele simplesmente porta os atributos de um imperador romano”. 
em dois canais do áudio, há paralelamente espacialização ao vivo em oito canais por meio do algoritmo desenvolvido no Ircam, o Spat. ${ }^{11}$

Exemplo sonoro 5 - Trecho de Nomoi, para violino e live-electronics ${ }^{12}$

3) Introdução de novos materiais concomitantes e provenientes da esfera instrumental, que chamaremos daqui em diante de adição instrumental

Conforme ilustrado na figura e exemplo sonoro seguintes, o papel principal das transformações eletroacústicas em Nomoi foi o de impingir aperiodicidades a uma escrita bastante periódica, regular para o violino, seja no âmbito das durações (rítmicas escritas de maneira extremamente regular levadas a resultados irregulares, dispersos), seja no âmbito harmônico-timbrístico (ampliado pela agregação de alturas pelos recursos eletrônicos e alterações espectrais). $\mathrm{O}$ início da peça ilustra bem esta expansão rumo a uma aperiodicidade:

Figura 4 - Trecho inicial de Nomoi, para violino e live-electronics

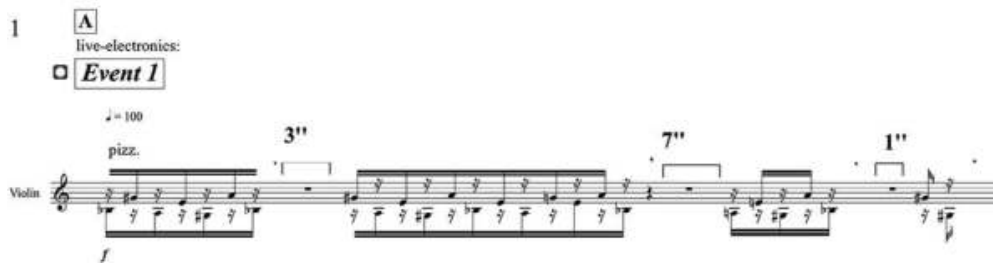

Fonte: Gati (2013).

11 A programação em Max/MSP foi realizada por André Perrotta. A estreia foi em outubro de 2013 no Sesc Consolação, com Elissa Cassini ao violino.

12 Disponível em: <https://soundcloud.com/tiago-gati>. 
Exemplo sonoro 6-Nomoi, abertura ${ }^{13}$

Como se pode notar na comparação entre a escrita instrumental e a escritura construída com recursos eletroacústicos por meio do exemplo sonoro anterior, o direcionamento a um resultado aperiódico ocorre no aumento da complexidade em duas frentes, tanto na distribuição temporal de eventos (multiplicam-se as notas em pizzicato por meio de delays com vários intervalos de tempo) quanto no campo frequencial (a partir de um grupo fixo de alturas definido para ser tocado pelo violino há uma explosão no registro de transposições em tempo real a um espaço frequencial não temperado). Isto sem mencionar o critério espacial, da pulverização dos sons pelo espaço da performance -a estreia foi realizada com o auxílio de oito alto-falantes ao redor do público.

A adição instrumental pode ser observada em inúmeros casos, como na obra Désintégration (1983), para ensemble, em que Tristan Murail pretende que a esfera eletroacústica atuante (bande, referente a fita magnética) seja tão "instrumental" que a dispõe na partitura como um segundo ensemble escrito. Para a performance, este material eletroacústico é proveniente de gravação prévia do ensemble e deve ser projetado juntamente com a execução instrumental. Esta atitude de Murail em relação à notação dos materiais pré-gravados é também encontrada, por exemplo, em obras mistas de Jonathan Harvey.

Harvey utilizou recursos eletroacústicos para atuar diretamente na distribuição espectral de corpos instrumentais. Particularmente em suas peças para instrumentos e tape, como na trilogia Inner Light a partir de 1973, os sons pré-elaborados em estúdio atuam ora como realces de parciais de notas tocadas pelos instrumentos, ora como alturas que compõem o campo harmônico definido pelo compositor, ora como interferências que levam de um parcial a outro, de um harmônico a outro, buscando criar mudanças espectrais sutis e integrar a estruturação harmônica (pensada como campo discreto de alturas) com a caracterização espectral em si: "minha predileção estética é

13 Disponível em: <https://soundcloud.com/tiago-gati>. 
integrar mais e mais; por meio de transições contínuas timbres são integrados à estrutura e [...] estrutura integra-se ao timbre" (Harvey in Emmerson, 1986, p.180). ${ }^{14}$

Comentando seu segundo trabalho realizado no Ircam, Bhakti, Harvey (ibidem, p.183-4) revela pistas curiosas sobre a diferenciação entre o ambiente eletroacústico e o instrumental, assim como para nós, aqui, o mais importante - suas mesclas, contatos:

Eu senti as diferenças sociais e espirituais entre a música proveniente de alto-falantes e a música tocada ao vivo como sendo esteticamente insuportáveis e que elas deveriam ser contrapostas tornadas ambíguas - por meio da maior similaridade possível entre o som, a estrutura do tape, e a música executada ao vivo. Adicionalmente, os inúmeros pequenos desvios no tape em relação à estrita imitação instrumental podem ser mais eficazes, porque o ouvinte infere de maneira precisa o quão distantes estão de sua "base". Um plano frontal pode ser composto contra um claro plano de fundo. Ambiguidade está constantemente presente já que o ouvido não tem certeza se os sons são provenientes do tape ou do intérprete ao vivo. Esta fronteira é intrigante: os cálculos necessários para criar identidades precisas e o terreno comum das ambiguidades dançam delicadamente com as associações culturais dos instrumentos, advindas de vários séculos de uso. ${ }^{15}$

14 É interessante notar que, assim como no exemplo dado de Murail e em outras obras com fita magnética do compositor britânico, como Bhakti para 15 instrumentos e tape (1982) e Tombeau de Messiaen (1994), o tape é encarado como uma extensão tão contínua da escritura instrumental que é inclusive escrito na partitura em notação convencional. Tristan Murail também revela uma particular busca por criar um continuum entre elaboração harmônica e timbre em Mémoire-Érosion, para trompa e ensemble (1976). O compositor francês revela, por exemplo, ter valorizado intervalos de $12^{\mathrm{a}}$ e $17^{\mathrm{a}}$, bastante pronunciados nas arcadas em sul ponticello (parciais 3 e 5) dos instrumentos de corda (Murail, 2000, p.6-7).

15 No original: "I felt the social and spiritual differences between loudspeaker music and live-player music to be aesthetically insupportable and that they should be contradicted - made ambiguous - by having the sound and structure of the tape music as similar as possible to the live music. In addition, the numerous small departures 
Dadas as possibilidades desenvolvidas em diversos graus nos itens elencados acima - e, obviamente, não limitadas a elas -, podem ser criadas ambiguidades que passam a enriquecer a performance, ambiguidades estas que habitam o material musical em si - de qual fonte provém este som que ouço? Como foi gerado? É processado ao vivo ou não? - até a própria dinâmica da performance, colocando em dúvida constante o que se ouve em relação ao que e onde se vê, tornando as possíveis deformações do gesto instrumental uma problemática essencial da composição mista.

Denominaremos, daqui em diante e em seus diversos níveis, essas ambiguidades, distorções, anamorfoses na música eletroacústica mista. $\mathrm{O}$ conceito de anamorfose parte de um contexto visual relativo às deformações de imagens ao olhar, como no caso dos espelhos não planos, e foi aplicado à percepção sonora por Pierre Schaeffer no seu Traité des Objets Musicaux (1966, livro III, capítulos XII a XIV). No capítulo seguinte trataremos de investigar melhor este conceito com o intuito de ampliá-lo, para abarcar as deformações dos meios instrumentais pelos meios eletroacústicos.

Até aqui, é importante dizer que os exemplos precedentes enfocam prioritariamente situações de fusão espectral ou que atuam no limite para o contraste entre as esferas instrumental e eletroacústica, situações estas que possibilitam o surgimento de anamorfoses. Podemos elencar assim duas situações de anamorfoses na música mista:

1) Adição instrumental: é a esfera eletroacústica que agrega materiais oriundos e ainda bastante característicos do corpo instrumental em questão.

in the tape from strict instrumental imitation can be more effective because the listener gauges so precisely how far removed they are from their 'base'. A foreground can be composed against a clear background. Ambiguity is constantly present in that the ear is often unsure whether it is hearing tape or live player. This borderland is intriguing: the numbers necessary to create precise identities and the middle ground of ambiguity dance in delicate play with the instruments' cultural associations, created by several centuries of usage". 
2) Similaridade espectral: há imitações de qualidades espectrais de uma ou outra esfera. Esta delimitação se aproxima do conceito de transferência espectral, desenvolvido por Menezes. ${ }^{16}$

Vejamos agora um exemplo de Parcours de l'Entité que, a partir da adição instrumental - materiais gravados oriundos da percussão e da flauta -, permitirá notar diferentes graus de distanciamento entre o que é executado ao vivo e em tempo diferido; nos casos de maior afastamento e distinção entre as duas esferas há, mesmo assim, transferências espectrais que conferem uma forte unidade ao material. O primeiro exemplo sonoro a seguir reproduz somente o tape; é no segundo exemplo sonoro que podemos ouvir o resultado global do trecho com a esfera instrumental "ao vivo".

Exemplo sonoro 7 - Transferências espectrais em Parcours de l'Entité (somente o tape)

Exemplo sonoro 8 - Transferências espectrais em Parcours de l'Entité (tape e corpo instrumental) ${ }^{17}$

Figura 5 - Trecho da página 2 da partitura de Parcours... correspondente aos exemplos sonoros acima

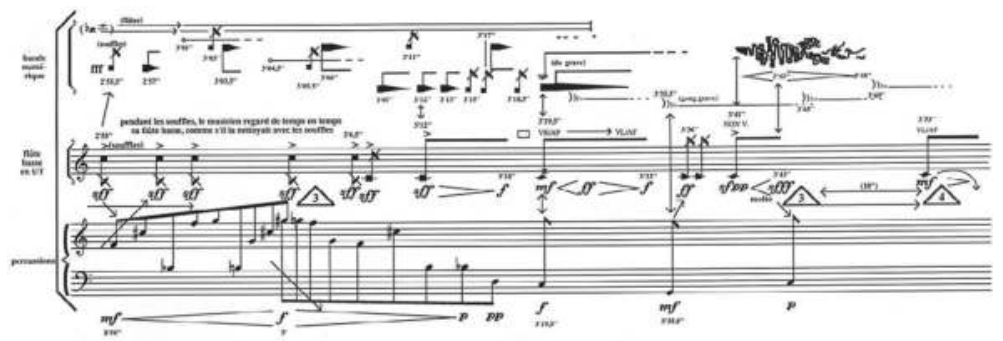

Fonte: Menezes (1998).

16 "Para haver fusão entre as escrituras instrumental e eletroacústica, será necessário que haja transferências localizadas de características espectrais de uma esfera de atuação à outra" (Menezes, 2006 [2001], p.385-6).

17 Disponível em: <https://soundcloud.com/tiago-gati>. 
Mesmo que o resultado auditivo seja bastante "instrumental", por assim dizer, a anamorfose surge não só pela desconexão audiovisual em situação de performance como também nos pequenos desvios espectrais de certos sons na esfera eletroacústica, que são "retocados", distorcidos levemente pelo compositor (a maior distorção neste trecho corresponde ao "sopro" advindo de materiais de flauta e transferido ao estrato eletroacústico, indicado na figura anterior pelos elementos gráficos na bande numérique).

Há ainda um caso particular de interação em que a esfera instrumental sofre alterações de timbre pelos processos eletroacústicos mantendo, no entanto, um vínculo energético com o movimento do performer e com o que seria esperado do instrumento musical utilizado, isto é, o som resultante segue um envelope dinâmico condizente com o movimento humano a um dado instrumento musical - não nos surpreende tanto em termos de deslocamento temporal com o estrato eletroacústico quanto no nível da qualidade espectral. Isto resulta, como veremos em seguida na obra Instantânea (Ruviaro, 2005), para piano e eletrônica em tempo real, em um instrumento musical composto, ampliado pelo aparato eletroacústico.

Figura 6 - Trecho inicial de Instantânea, de Bruno Ruviaro

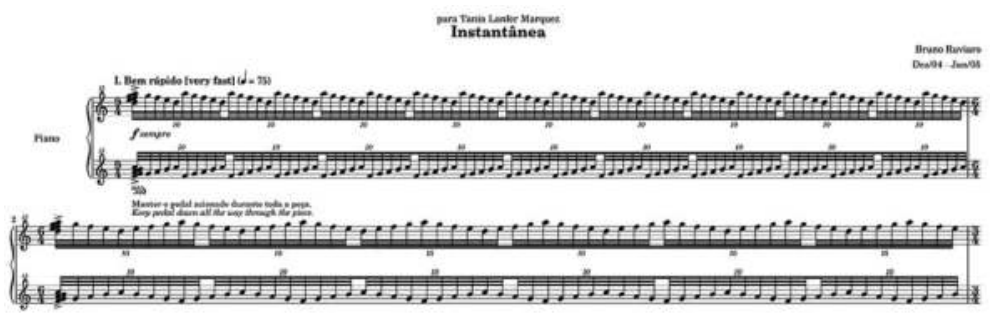

Fonte: Ruviaro (2005).

Exemplo sonoro 9 - Bruno Ruviaro: trecho de Instantânea (piano e eletrônica em tempo real $)^{18}$

18 Disponível em: <https://soundcloud.com/tiago-gati>. 
O início da obra apresenta uma situação de total fusão entre o som produzido pelo piano (preparado com fitas adesivas que abafam o som das cordas) e pelo processamento eletroacústico em tempo real. $\mathrm{O}$ envelope dinâmico do som resultante é próximo ao que seria o do piano sem a intervenção eletrônica, ou seja, o comportamento temporal do som resultante é familiar, condizente com o gesto do pianista. A anamorfose que atua no gesto instrumental é de ordem eminentemente espectral, não tanto no nível do envelope dinâmico: a surpresa acontece principalmente no conteúdo espectral que esperamos ouvir do piano. Nesta grande seção, ouve-se um novo instrumento, modificado não somente pela preparação, mas também pela ampliação e transformação espectral pelos recursos eletroacústicos (programação em Max/MSP). Aqui, portanto, a eletrônica em tempo real radicaliza a modificação espectral já realizada pela preparação.

Mas como este instrumento difere de fato do piano preparado? Adotemos uma situação hipotética: imagine um piano preparado. Agora imagine que o amplifico. A amplificação por si traz não só uma "qualidade espectral" particular, mas um gesto vinculado a possíveis transformações que podem estar ocorrendo via recursos eletroacústicos. É evidente que isto depende da experiência musical e de um repertório por parte do ouvinte, mas, neste caso, o vínculo energético - em termos de uma ação do intérprete condizente com o encaminhamento energético esperado para o som mesmo após o processamento - tende a minimizar a diferença entre o piano preparado e o instrumento da peça de Ruviaro, que surge como uma espécie de extensão contínua, uma ampliação timbrística do piano (assim como o piano preparado de John Cage).

Sem dúvida instaura-se uma ambiguidade com relação à qualidade espectral, uma anamorfose: ao ver o piano no palco, surpreendemo-nos com o resultado sonoro produzido, embora a maneira de tocar, como no piano preparado, se mantenha. Esta é uma situação, portanto, que nos parece importante por ser um caso-limite em que a anamorfose no gesto instrumental na música mista se aproximaria até a uma anamorfose na música instrumental sem recursos 
eletroacústicos, não fosse a qualidade espectral típica resultante que constitui um gesto da música eletroacústica - dificilmente, por exemplo, o compositor chegaria às especificidades do timbre realizado pelo live-electronics somente com uma preparação do piano.

Em correspondência de Ruviaro com este autor, o compositor ressaltou o aspecto da fusão no que se refere ao posicionamento dos alto-falantes no palco: de forma sintomática, a mescla almejada por Ruviaro com o estrato eletroacústico "não seria possível" sem um posicionamento específico das caixas acústicas, reforçando nosso argumento da diferenciação entre o instrumento criado com recursos eletrônicos e o piano preparado:

Um ponto crucial da Instantânea, para mim, é que foi a primeira vez que eu experimentei com o posicionamento dos alto-falantes próximos ao piano (de preferência debaixo do piano, ou ao lado e para trás). Marco Stroppa faz muito isto, com o mesmo objetivo: reaproximar o som eletroacústico fisicamente do local de onde vem o som instrumental, com o intuito de alcançar uma mistura que de outra forma não seria possível (alto-falantes nos cantos do palco não funcionam bem para este fim). Claro, isto que falei acima é somente um detalhe da realização técnica que serve ao objetivo musical que você está discutindo - a fusão tímbrica do acústico e eletroacústico. Mas costumo pontuar este comentário com respeito à peça já que penso fazer bastante diferença na performance, e nem todo performer que vai tocá-la tem esta consciência ou experiência a princípio. 


\section{Anamorfose}

Dicionário Littré: ${ }^{19}$

s. f. $\left(a-n a-m o r-f \hat{o}-z^{\prime}\right)$

Imagem deformada desenhada sobre uma superfície plana que, refletida por um espelho cilíndrico vertical, resulta em uma figura regular..$^{20}$

Etimologia: palavra grega fictícia derivada de outra palavra fictícia, sendo esta última proveniente do prefixo ANA que indica transposição, e do termo grego que significa forma. ${ }^{21}$

Dicionário Aurélio (Ferreira, 1999, p.131):

[do gr. anamórphosis, 'transformação'.] s. f. 1. Biol. Evolução contínua, sem etapas descontínuas ou saltos. [...] 3. Ópt. Deformação de uma imagem formada por um sistema óptico cuja ampliação longitudinal é diferente da ampliação transversal.

Dicionário Houaiss ${ }^{22}$ :

1. art. plást representação de figura (objeto, cena etc.) de maneira que, quando observada frontalmente, parece distorcida ou mesmo irreconhecível, tornando-se legível quando vista de um determinado ângulo, a certa distância, ou ainda com o uso de lentes especiais ou de um espelho curvo.

$[\ldots]$

19 Dictionnaire de la langue française, par É. Littré. Texto integral disponível em $<$ http://www.littre.org/>.

20 No original: "Image déformée dessinée sur une surface plane, qui, réfléchie par un miroir cylindrique vertical, offre une figure régulière".

21 No original: "Mot grec fictif dérivé d'un autre mot fictif, ce dernier provenant de ANA indiquant transposition, et du terme grec signifiant forme".

22 Grande Dicionário Houaiss. Disponível em <http://houaiss.uol.com.br/ >. 
5 ópt. deformação de uma imagem obtida por um sistema óptico que permite uma variação da ampliação transversal relativamente à ampliação longitudinal.

Etimologia:

anamorf(o)- + -ose; cp. gr. Anamórphōsis, 'formado de novo'

A metáfora do espelho, extremamente valiosa na arte especialmente quando faz referência direta à imitação, põe a imagem em evidência: imagem de um objeto, que no caso das coisas reflete seus diversos ângulos conforme as condições da luz e da posição relativa que ocupa frente ao observador, e no caso de um sujeito atua como metáfora ao próprio "eu". A imagem é o reflexo de algo que vemos e que adquire um estatuto próprio, uma autonomia em relação a sua contraparte "real". Danto nos traz um argumento muito válido para pensar o dado sonoro como imagem, autônoma em relação ao objeto de origem, analisando o estatuto da imagem em dois contextos distintos: Platão e Hamlet. É curioso que em A república, no livro X, Platão (apud Danto, 2005, p.43) tenha vislumbrado a "perfeição" mimética na mais clara imagem da realidade não pelos meios de representação de então, mas precisamente por meio de um espelho: "Em breve criarás o Sol e os astros, e a Terra e a ti mesmo, e os outros animais e plantas, e todas as demais coisas das quais acabamos de falar, no espelho". Pode-se pensar em certa aflição demonstrada por Platão no tocante à condição da "arte" de seu tempo: questiona a necessidade mesma de outro meio de representação da realidade já que podemos experimentá-la pessoalmente, esta mesma realidade que já temos dada diante de nós.

Hamlet, no entanto, apresenta uma condição de incerteza no espelho, ao mesmo tempo em que revela uma perspectiva única de poder olhar a si próprio, poder formar uma imagem de si e ver-se enfim como centro das mais diversas contradições:

Hamlet: Vamos, vamos, sentai-vos; não vos movereis.

Nem saireis daqui, sem que eu vos ponha aos olhos 
Um espelho onde vejais o fundo de vossa alma.

Rainha: Que queres tu fazer? Pretendes me matar?

Socorro! Aqui! Socorro!

[...]

Ó Hamlet.

Não fales mais. Fazes que eu volte o meu olhar

Para o interior de minha própria alma, e aí

Diviso manchas negras, de tão firme cor,

Que não sairão jamais. ${ }^{23}$

Esta ideia de constituir uma imagem cujos contornos e atribuições de significados ensejam uma intenção, e com variações e nuances sempre em movimento, estiveram ligadas ao papel que o espelho carrega contendo, inclusive, possíveis deformações face ao que se espera ver. A anamorfose, retrato destas distorções, traz um elemento importante no que se refere ao comportamento da imagem, que pode ser moldada de forma a realçar um traço de ilusão presente no olhar, já que só a partir de certos ângulos sou dado a ver a forma "real" do objeto representado no caso de um espelho curvo. ${ }^{24}$

François Bayle fala em anamorfose como uma das ações possíveis de serem realizadas em um som a partir de procedimentos eletroacústicos, caracterizando diferentes aspectos morfológicos das “imagens" sonoras. Partindo do raciocínio de que a imagem sonora

23 Versão em português presente em Shakespeare (1976). No original (Hamlet, Prince of Denmark. Cena IV, Ato III): "Ham. Come, come, and sit you down; you shall not budge: / You go not, till I set you up a glass / Where you may see the inmost part of you. / Queen: What wilt thou do? Thou wilt not murder me? / Help, help, ho! / [...] O Hamlet, speak no more! / Thouh turn'st mine eyes into my very soul; / And there I see such black and grained spots, / As will not leave their tinct" (Shakespeare, 1993).

24 Abordei as relações entre esta ilusão visual e a ilusão do relevo sonoro na conferência Immersion, presence and Drama in the Musical Space of Performance with Loudspeakers na Universidad Autónoma de Madrid em março de 2013, comparando a necessidade de situar-se em um ponto específico de observação tanto para apreciar com clareza a ilusão em obras pictóricas que realizam um trompe l'oeil (literalmente, "enganar os olhos") quanto para perceber uma trajetória sonora circular cuidadosamente elaborada em estúdio por meio de alto-falantes. 
tem o poder de "converter o tempo em objeto", assim podem ser, em suas palavras, os diversos processos de transformação de um som:

podem-se aplicar aí limitações tais como torção, deformação, inversão: anamorfose (ana: refazer);

pode-se, a partir de duas imagens, produzir uma terceira, híbrida, por mascaramento e cruzamento contínuo de traços: metamorfose (meta: sucessão);

pode-se analisar a imagem para gerar ou sintetizar outras imagens: morfogênese. (Bayle, 1993, p.85) ${ }^{25}$

Interessa-nos neste trabalho a situação do dado instrumental quando não totalmente transformado, metamorfoseado, por um tal distanciamento ao gesto instrumental que este perca sua identidade, mas deformado até certo limite: na peça de Ruviaro, por exemplo, vista no item anterior, apesar da distância radical que o meio eletroacústico impõe em termos espectrais ao piano, permanece o vínculo energético entre sons eletroacústicos com a ação do intérprete e, mais ainda, permanece uma similaridade em termos de envelope dinâmico entre o som resultante e o ataque "seco" (staccato) no registro médio de um piano não preparado. E isto possibilita algum nível de identificação com o gesto do piano, precisamente na maneira de tocar: há, então, anamorfose.Por outro lado, poderia haver anamorfose também se imaginássemos que na peça de $\mathrm{Ru}$ viaro o processamento em tempo real desvinculasse temporalmente em diversos níveis o som resultante das notas tocadas em um piano não preparado - por exemplo, por meio de delays e transposições das alturas tocadas. ${ }^{26}$ Neste segundo caso, o gesto instrumental

25 No original: “- on peut y appliquer des contraintes telles que torsion, déformation, inversion: anamorphose (ana: en remontant); / on peut à partir de deux images en produire une troisième, hybride, par masque et croisement continu de traits: métamorphose (méta: succession); / on peut analyser l'image pour générer, synthétiser d'autres images: morphogenèse."

26 É precisamente isso que ocorre no início de Nomoi, para violino e live-electronics. Harvey também realiza essa mesma ideia, em tempo diferido, em Tombeau 
também é deformado por deslocamentos temporais. Na música eletroacústica mista, realizar uma anamorfose em um objeto sonoro frequentemente leva a uma condição de dúvida frente ao material por conta da dualidade com o gesto instrumental - que enseja a história, o repertório e a própria ação instrumental -, tornando ambíguos os momentos em que o material se porta como se fosse mais "inumano" ou mesmo desconectado, deslocado ou fragmentado face ao percurso instrumental.

Uma imagem deformada pressupõe que o objeto original ainda está lá, mesmo que mascarado: um círculo desenhado no papel e visto de lado se deforma em uma elipse, mas continua sendo um círculo no papel. As duas formas convivem, permitem um "lá-e-cá" do ponto de vista da observação. Algo similar é muito presente na música mista: por mais que se deforme um objeto, a anamorfose reflete o estado em que ele convive com um "outro", que se mescla a ele. $\mathrm{O}$ ataque inicial de Parcours de l'Entité é o ataque em um instrumento metálico (uma bigorna), mas passa por uma transição até um som flautado criado artificialmente, transição esta que reflete um momento ambíguo, que remodela um som inicial para chegar a outro. $\mathrm{O}$ objeto sonoro global é único, mas a imagem dele reflete tanto o metal quanto a flauta. A anamorfose está no entrevir, no reflexo mutável, na transição, na ilusão.

Eventualmente, o objeto "real" estará tão distorcido que será irreconhecível, como no quadro clássico The Ambassadors de Hans Holbein The Younger (1533), que, visto frontalmente, dispõe uma figura "estranha" ao centro: somente vista de lado, quando nos afastamos lateralmente diante do quadro, é que a figura toma sua forma "correta", uma caveira ${ }^{27}$.

Mesmo havendo deformações em diferentes intensidades, a condição de dúvida acaba sendo muito constante na música mista

de Messiaen, para piano e tape: os sons eletroacústicos adicionam notas do piano transpostas a alturas correspondentes a doze séries harmônicas, uma para cada nota temperada, causando uma sensação de "desafinação".

27 É possível consultar a figura no link: http://www.nationalgallery.org.uk/ paintings/hans-holbein-the-younger-the-ambassadors. 
precisamente pelo referencial "real" do instrumental presente, nas aproximações e distanciamentos que o material musical realiza entre suas esferas eletroacústica e instrumental:

O moto da atualidade resume-se [...] na coexistência não pacífica dos oponentes, na constante dúvida que permeia a dicotomia sígnica presente em cada ato da comunicação, na ilusão desfeita a cada momento de que se está diante da indubitável unidade da coisa percebida, na riqueza da diversidade perceptiva presente na complexa, equívoca e propulsora dramaticidade sígnica, dramaticidade esta presente - no que se refere às estruturas musicais - no bojo de cada gesto musical: ser e não ser; eis, pois, a condição de nossa atualidade estética [...] A certeza da coexistência não pacífica entre a coisa e sua representação transmuta-se, na música eletroacústica mista, em uma outra: em uma profícua, constante e dúbia ilusão. (Menezes, 1998)

\section{Anamorfoses temporais e funcionais segundo Pierre Schaeffer}

Nos capítulos XII, XIII e XIV do seu Traité des Objets Musicaux (1966), assim como no quarto tema de reflexão do Solfejo do objeto sonoro (1967), Pierre Schaeffer introduz o conceito de anamorfoses temporais, emprestado (como tantos outros também o seriam na análise e terminologia geral da música eletroacústica) de um meio puramente visual, conforme já mostramos. Schaeffer vinculou o termo anamorfose inicialmente a uma investigação de como funciona nossa percepção sonora do passar do tempo, da identificação do antes e do depois face à medida física do tempo. As anamorfoses temporais, para ele, foram uma maneira de esclarecer que a percepção auditiva não era redutível a uma unidade de medida:

o termo anamorfose refere-se a [... ] certas "irregularidades" marcantes na passagem da vibração física ao som percebido, levando a pensar em uma espécie de deformação psicológica da "realidade" física, 
e tais irregularidades traduzem simplesmente a irredutibilidade da percepção à medida física. (Schaeffer, 1966, p.216)28

As anamorfoses temporais compreendiam, desta maneira, o deslocamento que age entre a passagem do tempo "medido" e nossa percepção desta mesma passagem enquanto fenômeno apreendido, de eventos sonoros localizáveis em um eixo antes-depois que toma proporções deslocadas frente a uma realidade física mensurável. Comparando ainda dois sons que eventualmente possuam o mesmo tempo "cronométrico", a mesma duração, nossa percepção pode distingui-los em duração se um deles contiver muito mais informação espectral que o outro. ${ }^{29}$

A partir de 1957, há inúmeras experiências de Schaeffer neste campo que relatam uma preocupação fundamental com o ataque dos sons, transiente que parecia ter importância predominante na percepção global de diversos sons instrumentais. O transiente de ataque foi então estudado em diferentes instrumentos musicais: tomando uma mesma nota articulada em staccato tocada oito vezes em sequência por um trompetista (com a intenção de tocá-las da forma mais semelhante possível), Schaeffer (1966, p.215) obtém imagens no osciloscópio de oito figuras razoavelmente diferentes, provando certo mistério e complexidade relacionados não somente ao início destes sons, os fenômenos transitórios que dariam origem a ele, mas também a como objetos sonoros bastante similares em termos auditivos podem apresentar curvas dinâmicas visualmente tão díspares.

28 No original: "Le terme anamorphose se rapporte à [...] certaines 'irrégularités' remarquables, dans le passage de la vibration physique au son perçu, faisant penser à une espèce de déformation psychologique de la 'réalité physique, et dont nous verrons qu'elles traduisent simplement l'irréductibilité de la perception à la mesure physique".

29 Outros compositores também investigaram a percepção da passagem do tempo em música, notadamente Olivier Messiaen e Gérard Grisey (deste último ver, por exemplo, "Devenir du son" e "Tempus ex machina" (2008), em que fala de uma "espessura do presente", existente entre dois eventos sonoros e variável conforme a caracterização espectral de ambos). 
Com a hipótese de ser o ataque um fator fundamental na percepção timbrística de um som, a ideia de Schaeffer foi, então, prosseguir seus experimentos a partir da supressão do ataque para observar o que ocorria cortando alguns décimos de segundo iniciais de sons instrumentais gravados. Por meio da experiência do som grave de piano - suprime alguns décimos de segundo, depois meio segundo e em seguida um segundo, sem alteração perceptível do som ouvido -, ele conclui, em primeiro lugar, que os complexos fenômenos transitórios iniciais e a insurgência física de um som não estão, necessariamente, ligados à percepção do ataque. Em outras palavras, o ataque percebido de um som e seu surgimento físico, seu início, não necessariamente coincidem. Da mesma maneira, a percepção temporal deste mesmo som pode não se alterar, mesmo com supressões significativas (em termos de décimos de segundo) de seu início. Contrariamente ao que se pensava no início, não é o ataque que define o comportamento de um som: é a curva dinâmica (sua forma global) que determina nossa percepção de ataque.

E aqui ocorreu uma constatação desta distorção, deste deslocamento denominado anamorfose temporal, entre a duração (medida física) de um som e sua efetiva percepção, já que o resultado auditivo propriamente dito nessa experiência do piano era essencialmente inalterado, ao passo que fisicamente houve a supressão do ataque por meio de cortes sucessivos no comprimento da fita magnética. O uso da fita, meio indispensável à época desses experimentos de Schaeffer, reforça ainda mais esta distorção revelada pelo experimento, já que uma porção de fita recortada manualmente não impedia que a nota, ao ser tocada novamente, estivesse aparentemente inalterada.

As experiências de Schaeffer a partir daí desvelam desdobramentos das anamorfoses temporais que acabam por recair nas suas formulações sobre a própria noção de instrumento musical e em outro conceito interessante, referente às transmutações instrumentais. Investigando os limites de reconhecibilidade e transformação do timbre no piano pelas manipulações na fita magnética, surgem comparações que nos servem para começar a pensar como operam 
as anamorfoses com as transformações eletroacústicas em um dado corpo instrumental, como são ampliadas as características de um instrumento até seu limiar de reconhecibilidade - adentrando o campo da anamorfose.

Retomando os experimentos com o piano estabelecidos por Schaeffer, surge uma pista curiosa: gravando uma nota grave tocada no instrumento, ele depois a transpõe por aceleração da fita a duas oitavas superiores; comparando com a nota "real" tocada duas oitavas acima, a transposição artificial é descrita como mais "rica" harmonicamente, porém com um ataque mais brando que o ataque da nota de fato tocada naquela altura. Trata-se, então, de uma ampliação do piano que se obtém pela transposição artificial com a alteração da velocidade de leitura do som gravado. E é a percepção deste instrumento ampliado, que ora pode nos chegar como uma ampliação, ora como um novo instrumento de fato, é precisamente neste limite, que entram em jogo as anamorfoses no âmbito dos materiais da música mista.

Para Schaeffer, a noção de instrumento musical evoca a "permanência de uma causa”, além, por suposto, de uma carga histórica que vincula a produção de sons característicos a determinadas fontes. No caso do piano, por exemplo, muito embora a curva dinâmica e o comportamento espectral de uma nota tocada no extremo grave seja muito diferente do extremo agudo, como podemos ver na figura a seguir, um ouvido relativamente treinado reconhece imediatamente que se trata de um piano. Fica claro, por outro lado, que não há necessidade de haver uma carga histórica para definir ou delimitar um instrumento capaz de produzir música, já que inúmeras obras musicais, em diversos períodos históricos, trouxeram sons provenientes dos mais inusitados objetos. Não nos interessa, obviamente, avaliar a pertinência do uso de uns ou outros instrumentos, mas sim as relações musicais que o ouvido faz e que conferem sentido musical às combinações desses sons. 
Figura 7 - Espectros e curvas dinâmicas de notas do piano tocadas do grave (esquerda) ao agudo (direita)
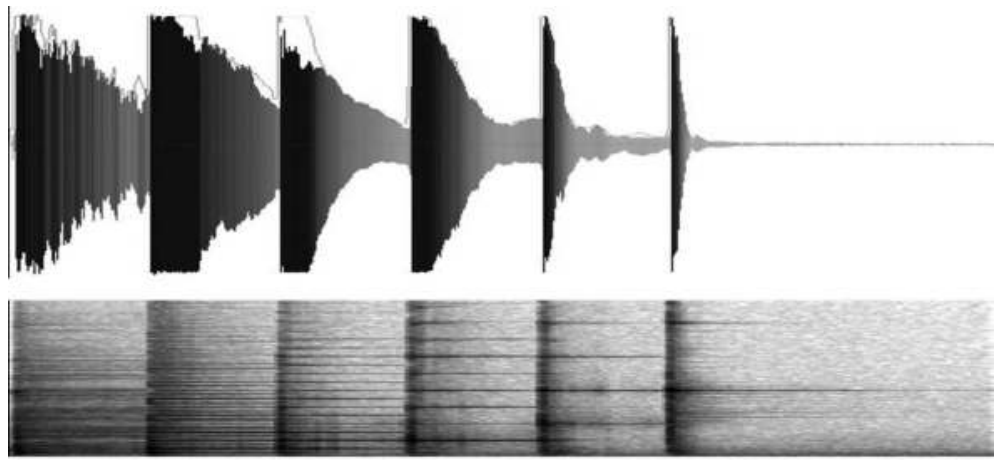

Repare que, na nota mais grave, a curva dinâmica (representada no plano superior da imagem) é menos inclinada, e o ataque tende a aderir aos transientes de decaimento e sustentação do som. A percepção de ataque é, desta maneira, mantida mesmo após cortes relativamente significativos da porção inicial do som.

Fonte: elaborada pelo autor

À parte a importância da investigação de Schaeffer acerca da noção de instrumento musical, tomarei outro aspecto em que o tema volta a ter relevância aqui: a noção de timbre instrumental. É neste conceito que surge o antagonismo entre causalidade e estrutura harmônica. Para além de identificar uma ou mais fontes sonoras que eventualmente estejam produzindo o que ouço, um pensamento musical que de fato conecta esses sons, relaciona-os uns com os outros, caracteriza esta oposição definida por Schaeffer entre causalidade e estrutura. Isto vai ser denominado anamorfose funcional, já que o timbre instrumental permite aproximar sons pelas características espectrais, sons esses que podem vincular-se por um elo estrutural, formar uma unidade, uma figura comum em um contexto - aqui a noção de figura se revela particularmente útil, já que Schaeffer se reporta ao aspecto estritamente funcional dos sons, destituídos de sua origem. A partir do estudo da anamorfose temporal e funcional podemos então começar a estender o uso do termo à música mista, abarcando distorções impingidas em um corpo instrumental por manipulações eletroacústicas que o afastam mais ou menos de seu "resultado" esperado enquanto instrumento reconhecível, ou, 
ainda, enquanto resultado sonoro esperado para um gesto realizado ou repertoriado.

\section{Anamorfoses na música eletroacústica mista}

O foco em uma apresentação ao vivo, visual ou musicalmente - e estou pensando aqui em performances solo-, é o intérprete. Assim, eu não abusaria de todo o potencial de um sistema de difusão como faço em peças para tape, porque exagerar na difusão tenderá a prejudicar as relações musicais cuidadosamente elaboradas entre o intérprete ao vivo e o conteúdo do domínio acusmático. Em outras palavras, há mesclas importantes, ambiguidades sonoras importantes que você destrói se intensificar demais a difusão do componente acusmático. Uma das coisas mais importantes na relação entre um instrumento e tape é o jogo de ambiguidades, e desejo mantê-lo e realçá-lo.

Denis Smalley ${ }^{30}$

É exatamente esta potencial contradição entre a presença humana e materiais sonoros que transcendem limites espaço-temporais a característica marcante da música mista. Por meio de uma situação de imersão pelo campo de atuação dos alto-falantes - que, como é o caso em muitas performances de música mista, envolvem o público -, um

30 No original: "The focus of a live performance visually and musically - and I am thinking about solo performance here - is the performer. So, I don't want to use as full a diffusion system as I do for tape pieces, because overdoing the diffusion will tend to undermine the carefully considered musical relationships between the live performer and the content of the acousmatic domain. In other words, there are important blends, important ambiguities of sound, which you destroy if you start over-diffusing the acousmatic component. One of the most important things about the relationship between an instrument and tape is the game of ambiguities, and I want to maintain and enhance this" (Smalley, 2000, p.14). 
constante estado de incertezas se apresenta ao ouvinte. Pensa-se aqui em dois tipos de situações criadas pelas anamorfoses:

1) quando se notam quebras, curtos-circuitos no gesto instrumental do ponto de vista energético pelas transformações eletroacústicas, causando uma "estranheza", sensação de desconexão;

2) quando a coexistência de materiais sonoros advindos de naturezas distintas pode dar origem a situações ambíguas (anamorfoses) em que uma esfera (eletroacústica ou instrumental) passa a "imitar" a outra em termos espectrais.

As anamorfoses atuam em uma zona de intersecção entre a "fusão" e o "contraste" das esferas instrumental e eletroacústica, nos momentos em que é instaurada a "condição de dúvida", nas mesclas envolvidas no ir-e-vir da situação de fusão. Os conceitos de fusão e contraste elaborados por Flo Menezes em Atualidade estética da música eletroacústica (1998) e no artigo Por uma morfologia da interação (2006, [2001]) fornecem um bom indício para compreendermos as anamorfoses:

Mesmo diante da mais convincente fusão espectral do instrumental com o eletroacústico, o ouvido sempre revelará aspectos de distinção da qualidade espectral oriunda do universo acústico daquela proveniente dos sons eletroacústicos, da mesma forma como buscará algum mínimo ponto de contato e identificação entre ambos os universos sonoros em meio ao contraste mais radical. (idem, 2006, p.383-3)

A esfera instrumental e estruturas eletroacústicas podem conviver fluidamente em uma espécie de híbrido (fusão) ou em situações de contraste, em que mostram mais claramente duas dimensões distintas do material musical. A partir desta distinção elaborada por Menezes, podemos inferir que é precisamente na zona de intersecção entre os dois estados que surgem situações ambíguas 
(anamorfoses); é no vai-e-vem ao contraste sutil que nos damos conta de que há a deformação, a anamorfose. Claro está que pode haver contraste e fusão, e a anamorfose atua entre elas, instaura a "condição de dúvida":

Para haver fusão entre as escrituras instrumental e eletroacústica, será necessário que haja transferências localizadas de características espectrais de uma esfera de atuação à outra [...] na fusão instaura-se uma condição de dúvida. Em certa medida, fusão implica propositadamente, da parte do compositor, confusão para o ouvinte [...] Ainda que de forma alguma hegemônico, o estado de dúvida traduz-se como momento supremo da interação. (idem, ibidem, p.385-6)

E são precisamente esses "estados de dúvida" que são aqui denominados anamorfoses na música eletroacústica mista; eles ocorrem no gesto instrumental, deformações da "realidade" física de um corpo instrumental pela ação do aparato eletroacústico. A fusão implica um estado em que as duas esferas se "confundem", mas a anamorfose que nos interessa mais aqui é a partir da esfera instrumental, do gesto do instrumentista: poderia sim haver "confusão" no fato isolado de haver transferências espectrais (imitações nas qualidades espectrais) entre um e outro objeto ou evento sonoro em um ambiente acusmático não referencial, seja pela igualdade de planos de profundidades, seja pela união (fusão) de seus espectros. Pense-se, por exemplo, na confluência de um plano sonoro de ruído rosa com outro de ruído branco, em que há certamente momentos de dúvida quando conformam um som híbrido; neste caso, a anamorfose ocorre, mas não guarda qualquer vinculação com o gesto instrumental pela junção entre materiais que não fazem referência ao seu domínio. Uma possível analogia surge: a transferência espectral, que confere características espectrais comuns a sons distintos, pode atuar então como anamorfose funcional conforme definida por Schaeffer.

Podemos pensar na abertura que o termo gesto instrumental permite, no sentido de tornar esta ideia de anamorfose na música eletroacústica mista mais ampla, abarcando inclusive certos 
mecanismos instrumentais que mais têm a ver com instaurar um processo. Mesmo assim, temos que considerar que um ataque em pizzicato em um violino tem um peso cultural incomparável com um objeto sonoro provocado por um processo como, por exemplo, o toque em um tam-tam que esteja acoplado a um colar de sementes, cujo movimento se realimenta da própria vibração do tam-tam. Podemos pensar então que é no gesto instrumental, no gesto com o sentido beriano, que traz uma história, que a anamorfose no caso da música mista tende a ser mais enfatizada. 
Parte II 


\section{3 \\ ANÁLISES MUSICAIS}

\section{Parcours de l'Entité (1994, Flo Menezes)'}

Com pré-estreia a 14 de maio de 1994 em Renfrew Ferry, Glasgow, na Escócia, e estreia a 5 de junho de 1994, no Festival Synthèse 94 (Palais Jacques Cœur, Bourges, França), Parcours de l'Entité foi a primeira obra realizada no Studio PANaroma de Música Eletroacústica da Unesp, ${ }^{2}$ inaugurado oficialmente em julho do mesmo ano.

A obra é composta para um flautista, um percussionista e sons eletroacústicos em tempo diferido (dois canais), com o uso de três flautas amplificadas (flauta em dó, flauta-baixo em dó, flauta em sol) e os seguintes instrumentos de percussão metálica: ${ }^{3}$

Gongos:

- $\mathrm{G} 2$ e D3, G4 e A4: gongos tailandeses

1 A partitura consultada foi editada pela Fundação Editora da Unesp (FEU) e acompanha o volume Atualidade estética da música eletroacústica (Menezes, 1998).

2 Embora os sons de síntese tenham sido gerados no Centro di Sonologia Computazionale (Pádua, Itália) em 1991.

3 Foram utilizadas as representações notacionais conforme indicadas na partitura. 
- B3: gongo coreano

- D4: gongo Koulington

- D5: gongo "Paiste" (tam-tam)

- F5: gongo chinês

- F4: gongo filipino

\section{Outros:}

- $\mathrm{C} 3$ e F4: cloche-plaque (plate Bell); uma aguda e outra grave

- $\mathrm{Bb} 3, \mathrm{~F} 4, \mathrm{~F} 5$ e G5: quatro triângulos diferentes

- C5 e G5: Crotales; Eb6: crotales tibetanos

Os sons eletroacústicos são provenientes do tratamento de materiais produzidos pelo próprio corpo instrumental já descrito, além de sons de síntese apresentados somente na última seção formal. A partitura já contempla a representação dos sons eletroacústicos pelo compositor ao lado da escrita instrumental.

No que se refere à estruturação harmônica da peça, partimos dos escritos do próprio compositor sobre os procedimentos e técnicas utilizados, conforme expostos em Atualidade estética da música eletroacústica (Menezes, 1998, p.82-108). Tal a sua importância, a concepção harmônica - entendida aqui no sentido de organização de alturas - origina o título mesmo da composição: a técnica dos módulos cíclicos desenvolvida por Flo Menezes parte de um aglomerado harmônico situado no domínio do temperamento denominado "entidade harmônica", que se desdobrará em um número limitado de transposições, retornando ciclicamente à entidade inicial: um dos sentidos do percurso da entidade. ${ }^{4}$ Esta técnica, aliada às projeções proporcionais, que veremos em detalhes a seguir, alimentará não somente a escrita das flautas, mas também a constituição espectral dos sons sintetizados na última seção da obra.

4 Será também relevante, como veremos, o percurso do flautista por sete diferentes posições determinadas no palco. 
É preciso ressaltar que, em virtude de um viés do compositor bastante fincado em processos organizativos de cunho serial, aliados, porém, a outro nível de organização estrutural que parte de características espectrais, frequentemente serão feitas incursões que migram o enfoque analítico dentro de um mesmo item do trabalho, tal a dificuldade em segregar a caracterização e evolução dos espectros da elaboração de alturas. ${ }^{5}$ Esta última, no entanto, adquire uma autonomia tal e com tal peso na poética do compositor que por vezes dominará o enfoque analítico.

\section{Considerações formais}

Em Parcours de l'Éntité a questão das segmentações formais também permeará o trabalho constantemente de modo a realçar os contrastes e características presentes em cada seção, mas parti das divisões mencionadas nos escritos do próprio compositor (Menezes, 1998), que concebeu a obra em três partes, como pode ser visto na tabela a seguir:

5 Nesse sentido, veremos que a polarização harmônica - consolidação de polos harmônicos, isto é, regiões harmônicas que orbitam ao redor de determinada altura preponderante - constitui uma importante referência à escuta, mesmo nos momentos em que a abordagem analítica é feita do ponto de vista das tipologias e contornos dos objetos sonoros. A noção de polarização harmônica subsidia ainda a primeira publicação do compositor, já em 1979 (Menezes, 1979, p.5). 


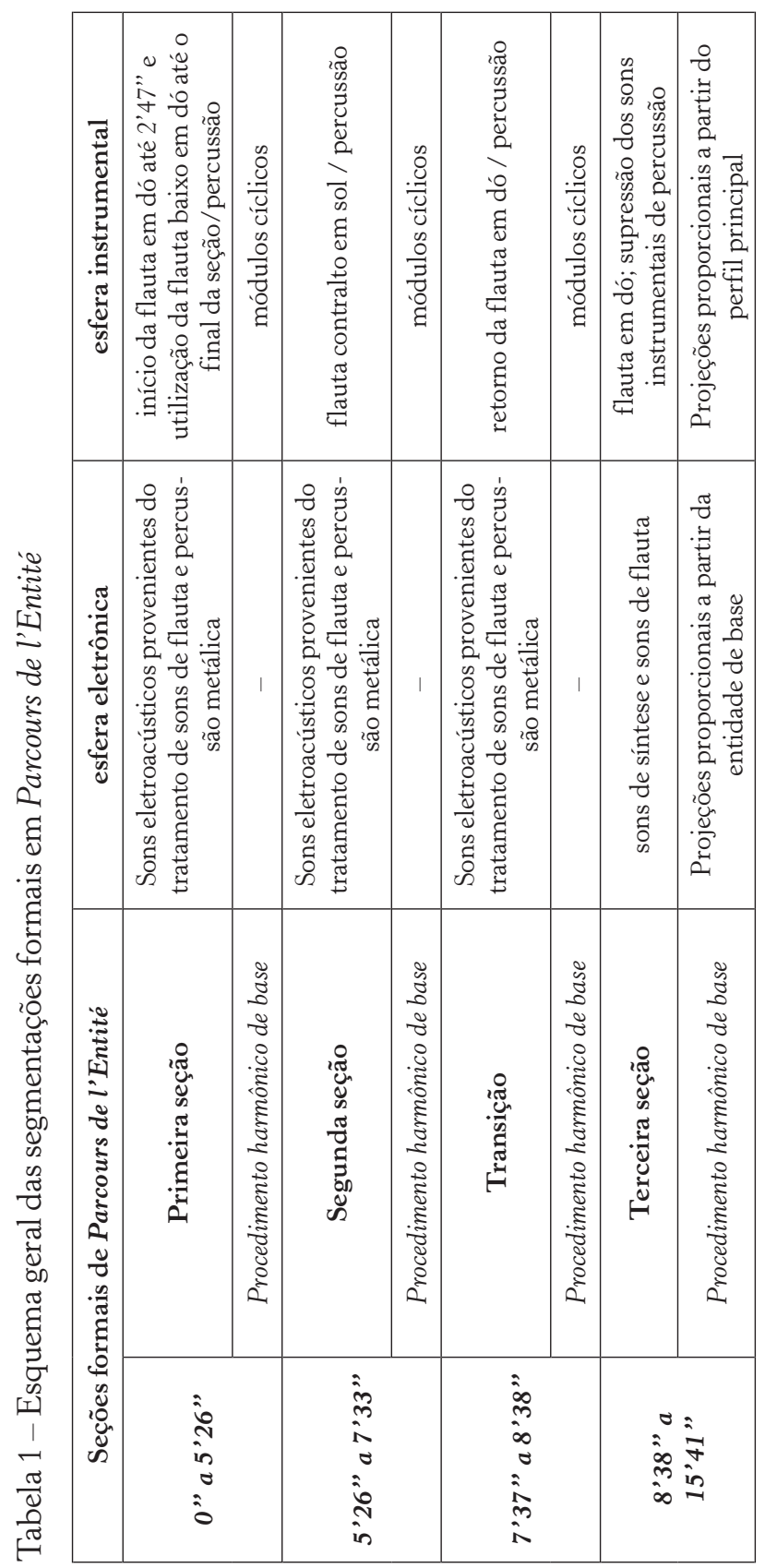




\section{A importância da estruturação harmônica em Parcours de l'Entité}

Antes de abordarmos a estruturação harmônica propriamente dita de cada seção, é oportuno tecermos alguns comentários sobre as técnicas e procedimentos utilizados pelo compositor: os módulos cíclicos e as projeções proporcionais. Como mencionado no início deste capítulo, ambas as técnicas, oriundas do início dos anos 1980, partem de uma entidade harmônica de base: ${ }^{6}$

Figura 8 - Simetrias e relações intervalares presentes na entidade harmônica de base utilizada em Parcours de l'Entité(Menezes, 1998)

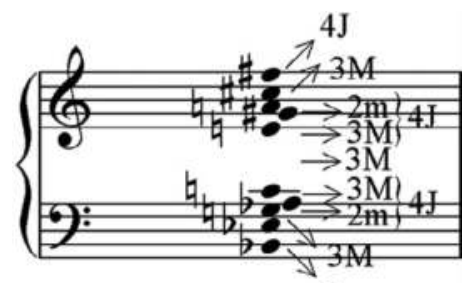

$4 \mathrm{~J}$

Fonte: elaborada pelo autor

Não se pretende aqui, evidentemente, detalhar de modo exaustivo os procedimentos técnicos utilizados por Flo Menezes para os módulos cíclicos e as projeções proporcionais, uma vez que o compositor já o faz de forma bastante extensa em seus escritos. ${ }^{7}$ Realizaremos, entretanto, uma breve incursão sobre as duas técnicas, em função da sua importância vital nesta obra e na poética do compositor.

6 "Toda estrutura intervalar que serve de base às manipulações dos módulos cíclicos constitui, por mais nova que seja, uma entidade harmônica" (Menezes, 1998). Esta mesma entidade foi utilizada, antes, em A dialética da praia (1993) e na obra inacabada ...Ora...

7 Ver Menezes, Apoteose de Schoenberg (2002 [1987]), Atualidade estética da música eletroacústica (1998) e Matemática dos afetos (2013). 


\section{Os módulos cíclicos}

As noções que subsidiam a técnica dos módulos cíclicos e suas aplicações sofreram constantes mudanças ao longo da trajetória composicional de Flo Menezes, ainda que a técnica em si tenha permanecido a mesma: inicialmente, a entidade de base era concebida a partir de aglomerados harmônicos que faziam referência a estruturas intervalares já conhecidas do repertório musical, ou seja, a "arquétipos harmônicos”. Por tal razão, ele cunha o termo "modalidades arquetípicas" para esta técnica na primeira versão de seu livro Apoteose de Schoenberg e em Berio et la Phonologie, revelando sua intenção, já naquela época, em ampliá-la para quaisquer entidades harmônicas de base, independentemente de constituírem arquétipos harmônicos como as entidades oriundas de Schoenberg, Berg ou Webern (Menezes, 2002). ${ }^{8}$

As relações que se desdobrarão a partir da entidade de base levarão em conta seus limites extremos (grave-agudo na direção vertical ou primeira e última nota na horizontal), delimitando um âmbito, assim como as relações intervalares internas. No caso de Parcours..., a formação do módulo cíclico resultará da replicação da estrutura intervalar da entidade de base em três transposições possíveis até que as disposições de alturas retornem exatamente como estavam no início - ou, nos termos do autor, em três retrotransposições:

8 A noção de arquétipo harmônico é bastante explorada por Flo Menezes e fortemente presente no pensamento de Willy Corrêa de Oliveira, seu professor de composição na USP. Em Apoteose de Schoenberg (Menezes, 2002 [1987]), esta noção pode ser entendida a partir de uma citação de Edmond Costère que leva em consideração uma "emancipação da dissonância” (em especial da segunda menor): "agora se admite que os acordes-tipo pelos quais os músicos da [Segunda] Escola de Viena substituíram o acorde perfeito assumem as formas Dó-Fá-Si, Dó-Sol-Si, Dó-Fá-Ré bemol ou Dó-Sol-Ré bemol, anteriormente tidos como dissonantes e levados à resolução" (Costère apud Menezes, 2002, p.114). Esses acordes-tipo, que contribuíram para "emancipar" a segunda menor de seu papel eminentemente melódico como sensível, foram amplamente utilizados pelos compositores vienenses e são mapeados por Flo Menezes no livro em questão. 
Figura 9 - Expansão via módulo cíclico da entidade de base de Parcours de l'Entité

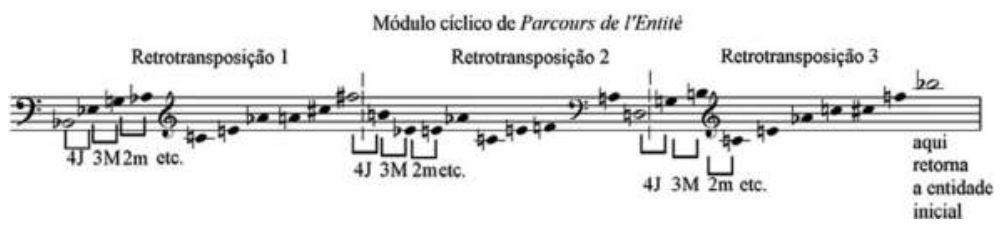

A replicação da estrutura intervalar ocorre até que se obtenham novamente as alturas na disposição inicial (retorno à entidade de base). As notas representadas por semibreves (Bb, F\# e D) são denominadas notas-pivô, comuns às retrotransposições.

Fonte: elaborada pelo autor

Determina-se a quantidade de transposições da entidade pelo intervalo no âmbito da oitava entre suas notas extremas; o número de retrotransposições será a quantidade de vezes em que ele é replicado até que se atinja a mesma nota de partida. Uma segunda maior, como no caso do arquétipo Skriabin (utilizado em PAN, de Menezes), replica-se seis vezes dentro de uma oitava, ocasionando seis transposições. Em Parcours..., cuja entidade de base compreende uma quinta aumentada entre suas notas extremas $\mathrm{Bb}-\mathrm{F} \#$, há apenas três retrotransposições (Bb-F\#-D-Bb). ${ }^{9}$

Os modos de transposições limitadas de Olivier Messiaen foram uma importante referência ao desenvolvimento técnico dos módulos cíclicos (idem, ibidem) - sete modos diferentes construídos de forma excludente (sem repetição de nota e não completando o total cromático), que permitem um número limitado de transposições até que se retorne às mesmas alturas de origem (portanto, uma ciclicidade). A técnica dos módulos, por sua vez, prescinde do critério exclusivo da não repetição - já na entidade de Parcours... há repetição (Ab-G\#) - e resulta em um número total de notas bem maior na constituição de um único módulo, tendendo a explorar com diferentes alturas

9 O mesmo ocorreria para um módulo cíclico cujos extremos formassem a inversão do intervalo absoluto de quinta aumentada ou sexta menor, a terça maior. O intervalo de quarta justa (e, consequentemente, sua inversão, a quinta justa) é muito interessante, porque leva doze transposições para retornar à nota inicial; com efeito, um módulo cíclico a partir de uma entidade cujos extremos formem uma quarta justa resulta em doze notas-pivô formando um ciclo de quartas. 
absolutas as mesmas relações intervalares da entidade de base; isto a diferencia de uma visão tipicamente modal (como no caso referido de Messiaen, instituindo um "reservatório de notas", um campo harmônico modular).

A não obrigatoriedade do total cromático na estrutura de partida (entidade), a possibilidade de repetição de notas e a ciclicidade - a adoção de uma estrutura que, replicada sequencialmente, retorna à exata disposição inicial - constituem, portanto, os aspectos fundamentais dos módulos cíclicos. Vejamos as considerações do próprio compositor:

Uma vez derrocada a convenção serial da não repetição, e uma vez debruçado sobre os interessantíssimos procedimentos de permutação serial cíclica propostos por Pousseur, interessaram-me sobretudo as características dos modos de Messiaen que justamente os faziam distinguir dos modos medievais, quais sejam: o convite à livre utilização de intervalos (não sendo mais necessário o aprisionamento ao grau conjunto); e a ciclicidade, já presente, coincidentemente, em minhas especulações [...]. Reneguei, assim, tanto o caráter excludente dos modos, prescindível na constituição de novas entidades (as quais poderiam ou não se servir do total cromático), quanto a até então "imprescindível" necessidade de se evitar a repetição de alguma(s) nota(s) no interior de uma determinada entidade harmônica (na qual poderiam existir, pois, notas reincidentes).

Assim é que podemos construir aglomerados harmônicos horizontalizados ou sequencializados - ou seja, campos harmônicos - a partir de arquétipos (acórdicos ou até mesmo diacrônicos, sequenciais) que nos interessem por tal ou qual motivo, constituindo, assim, conjuntos cíclicos sequenciais de intervalos, que se não podem ou não devem ser chamados de modos pela repetição possível de algumas de suas notas (contrariando, assim, uma das principais características genuinamente modais), devem ser chamados, pois, de módulos cíclicos: entidades harmônicas complexas, senão somente pela "simples" proliferação, via transposição num mesmo todo, de uma mesma entidade harmônica básica (arquetípica ou não) - não 
mais a partir, nota-se, de uma "série-de-base" -, também por possíveis relações multiarquetípicas contidas nesta nova expansão intervalar. (idem, ibidem, p.354-5)

Em Parcours..., o compositor determina a expansão do campo harmônico da entidade de base em um módulo, "um mesmo todo" com hierarquias internas, compostas por alturas distintas que valorizam a relativização do intervalo. A distinção da repetição e da incompletude cromática em cada retrotransposição de dez notas não impede que determinados usos do material se aproximem, em alguns momentos, de enfoques tipicamente "seriais": como será ainda observado, cada retrotransposição da entidade será utilizada separadamente em determinados trechos da primeira e segunda seções da obra com vistas a propriedades de polarização harmônica. É apenas na terceira seção formal que o perfil principal, uma reelaboração no registro do "todo" de 28 notas do módulo cíclico da figura anterior, se mostra em sua completude e se particulariza definitivamente.

Há uma saturação do total cromático no desenrolar de um módulo, ainda que cada retrotransposição não o faça obrigatoriamente; desse desenrolar resulta a elaboração de um perfil, que contribuirá para uma "redução entrópica do material" (idem, ibidem, p.368), uma maneira de viabilizar a exploração máxima das potencialidades auditivas da estrutura interna da entidade de base:

Afora casos excepcionais, em que o perfil das notas constitutivas do módulo já é claramente delineado em sua própria constituição, as notas que compõem um módulo são notadas de maneira arbitrária no registro das alturas, geralmente de forma concentrada no registro médio das frequências. Caberá à elaboração minuciosa da obra em questão precisar, conforme o contexto, o registro (perfil) e a exata sequência de notas. (idem, ibidem, p.364-5)

Expandindo-se a elaboração da entidade de base para além dos arquétipos (as estruturas intervalares herdadas do repertório musical), a escuta passa a contar ainda mais com outro elemento de 
fundamental importância, que acompanha o desenvolvimento dos módulos cíclicos: o perfil melódico. Conforme descrito pelo compositor, desde a elaboração de Phantom-Wortquelle; Words in Transgress (1986-87) o perfil contribui para a "escuta prática dessas entidades" (idem, 1998). A partir do módulo cíclico de Parcours..., foi criado o perfil principal, condizente com a tessitura da flauta em dó. O desenvolvimento "melódico" da terceira parte da obra se direcionará, como já antevisto, para este perfil.

Figura 10 - O perfil principal em Parcours...

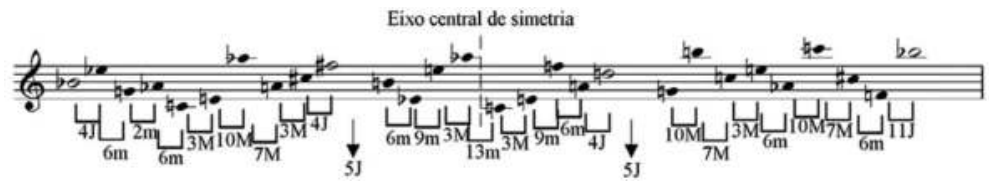

O perfil é constituído a partir do módulo cíclico, cujas simetrias oriundas da entidade de base formam, dispostas agora "horizontalmente", unidades perceptíveis recorrentes - uso de $2 \mathrm{~m}$, $3 \mathrm{M}, 4 \mathrm{~J}$, suas inversões e expansões de registro no âmbito de duas oitavas (correspondente à extensão da flauta em dó). O salto intervalar mais amplo situa-se exatamente no meio do perfil $(13 \mathrm{~m})$, atuando como uma espécie de espelho para as relações intervalares.

Fonte: elaborada pelo autor

Chegamos assim, para melhor entendermos as transformações harmônicas realizadas a partir da entidade, a um conceito bastante caro ao compositor: a composição de perfis. Podemos associar a este conceito as considerações bastante elucidativas de Pierre Boulez (1986) em um texto da década de 1950: “A experiência eletrônica mostra que essa noção de intervalo absoluto é fictícia, e que o poder discriminador da orelha depende em grande parte de uma unidade de base ou do âmbito do registro no qual tais intervalos se inserem". Com efeito, veremos em seguida que tanto o registro quanto alguns intervalos específicos e contornos serão fundamentais na elaboração harmônica de Parcours de l'Entité.

Pode-se pensar em uma associação com a linguagem verbal para esta questão dos perfis e sua audibilidade, que sempre será apenas parcial, sugestiva. Trevor Wishart (1996) argumenta que a escuta da fala se vale de alguns padrões intervalares e contornos próximos: 
Em um nível mais profundo, a análise computacional dos sons da fala mostra que os constituintes individuais sonoros (fonemas) não são justapostos uns aos outros da forma como se poderia elaborar em estúdio, mas na maioria dos casos elidem entre si muito rapidamente durante o ato do discurso. Ainda mais fundamental, muitas consoantes são caracterizadas por sua morfologia - a maneira como modificam sua forma - em vez de por seu espectro (distribuição de frequências ou características formânticas). (tradução livre)

Esta análise do discurso verbal encerra uma comparação fundamental com o decurso sonoro no contexto musical: eventos individuais como notas tocadas sequencialmente por um instrumento elidem umas nas outras, favorecendo a audibilidade do modelo do perfil enquanto contorno (fluxo contínuo) e não exclusivamente enquanto intervalo (salto discreto).

\section{As projeções proporcionais}

Quase simultaneamente à concepção dos módulos cíclicos nos anos 1980, Flo Menezes empreende investigações acerca de espaços harmônicos que por vezes são até mesmo distintos do temperamento, permitindo concreções e expansões intervalares por meio de uma espécie de "redimensionamento" da estrutura original, dando início às projeções proporcionais. O procedimento consolidou-se com Profils Écartelés, de 1988, para piano e sons eletroacústicos pré-gravados em quatro canais. Embora o corpo instrumental estivesse restrito ao temperamento, o compositor incorporou no estrato eletroacústico o universo microtonal oriundo de seis concreções intervalares de um dos dois módulos cíclicos utilizados na obra - em Parcours..., como veremos, o universo microtonal também foi explorado na escrita da flauta.

As projeções proporcionais, aplicadas à entidade de base, redimensionam o âmbito espacial coberto pelas notas extremas, "mantendo-se [...] a mesma proporção intervalar de origem" (Menezes, 1998). À maneira dos módulos cíclicos, a distribuição espacial das 
proporções obtidas pode ser utilizada em suas dimensões vertical ("acórdica") e horizontal ("melódica") - mesmo que a aplicação dos módulos envolva, em geral, a composição de um perfil de base, ela também possibilita o uso de outras entidades acórdicas derivadas -, com a distinção de que se buscaria com esta segunda técnica expansões e compressões intervalares: ${ }^{10}$

Se os módulos cíclicos se prestam muitíssimo bem à minuciosa e multiforme elaboração das estruturas harmônicas a partir do espaço frequencial constituído pelo sistema temperado, estruturação esta que pode servir e via de regra serve - como aliás demonstrado em A dialética da praia - às elaborações até mesmo independentes do temperamento, desejou-se, de qualquer forma, a edificação de um método de manipulação intervalar que permitisse transpor, no "espaço harmônico", as variações de dimensão perceptiva típicas das operações efetuadas sobre a escala temporal, quais sejam: dilatações e compressões de durações, a serem aqui convertidas, respectivamente, em expansões e contrações de estruturas intervalares. Elaborada em duas direções, a nova técnica contrapor-se-ia, sob este aspecto, aos módulos, já que estes implicam única e necessariamente "ampliação", ou seja, em expansão do campo harmônico da entidade originária. (idem, ibidem, p.85-6)

As projeções proporcionais podem aliar-se aos módulos cíclicos, podem eleger um dado módulo como sua estrutura de base, a ser proporcionalmente dilatada ou comprimida no espaço intervalar. Menezes revela que as projeções proporcionais levam às últimas consequências a técnica dos módulos cíclicos, abarcam esta

10 Os módulos, embora até possibilitem a exploração de terrenos microtonais, são em geral usados para uma "saturação cromática" a partir da entidade de base, sua expansão em um perfil que não só completa as doze notas distintas como também admite repetições. A possibilidade de compressão pelo uso das projeções proporcionais será especialmente útil, como ainda será visto, para as percepções de perfis melódicos com contornos muito próximos ao original, apenas "achatados" no espaço harmônico microtonal. 
possibilidade de concreção que está no cerne do desenvolvimento melódico tanto quanto das disposições verticais: "Uma vez aliada aos módulos cíclicos, a nova técnica poderia, de fato, potencializar ao máximo, como método composicional, quer a essência mesma das figurações melódicas, quer a das proporções acórdicas" (idem, ibidem, p.86). É possível, de fato, "estirar" ou "achatar" espacialmente (aumentar ou diminuir as distâncias entre os intervalos constituintes) tanto uma figura melódica quanto um aglomerado vertical, com a possibilidade de fazê-lo por meio de operações de redimensionamento também realizáveis no eixo das durações. Instaura-se, assim, uma busca especulativa por espaços harmônicos que diluem as distinções não somente entre vertical e horizontal como também entre temporal e frequencial.

Nesse ponto, o pensamento composicional de Menezes manifesta outras duas referências à geração do serialismo integral dos anos 1950:11 1) a teoria da unidade do tempo musical, de Stockhausen, que propõe um mesmo eixo temporal para frequências e durações - uma sequência de impulsos periódicos, por exemplo, percebidos "ritmicamente", ao ser acelerada converte-se na percepção de uma altura definida; 2) o esfacelamento da distinção entre horizontal ("melodia") e vertical ("acorde") - lembra-se que, partindo especialmente de Anton Webern e após a experiência do serialismo nos anos 1950, é abolida a segregação entre as duas dimensões na música como era previamente concebida. ${ }^{12}$

11 O próprio compositor analisa suas técnicas e procedimentos composicionais como de índole "pós-serial” (Menezes, 2002, p.390).

12 Boulez (2002, p.132-3) assevera: “Ampliada, a noção de vozes nos permitirá tornar 'porosas' as categorias como monodia, heterofonia, polifonia. Já se insistiu sobre o fato capital de que a série dilui a oposição entre horizontal e vertical [...]. O próprio Webern nos mostra claramente o caminho a seguir sem reservas, em suas obras com coro, especialmente; [...] Na Segunda cantata, onde estas relações chegaram a um estado inteiramente explícito, escolheremos primeiramente um exemplo simples, extraído do terceiro movimento. $\mathrm{O}$ antecedente, sendo confiado ao soprano-solo, exposto portanto horizontalmente, os três consequentes dividirão a frase em duas partes, a e b, para verticalizar a primeira (a), e deixar à segunda sua forma horizontal primitiva (b)". 
A concepção de uma entidade harmônica de base explorada à exaustão por via de módulos cíclicos e projeções proporcionais fornece materiais "melódicos" e "acórdicos" que visam constituir um espaço harmônico ampliado. Neste espaço os limites são imprevisíveis até que se manipule o material de origem com vistas a manter uma unidade; mas é precisamente nesta unidade que as técnicas de Menezes vão além das premissas seriais e adquirem, nas palavras do próprio compositor, uma "cor harmônica"13 que caracteriza a obra musical a partir dos elementos figurais ou constitutivos e demais estruturas derivadas de uma mesma entidade inicial.

As possibilidades de redimensionamento "proporcional" são aplicadas de duas maneiras pelo compositor: no sentido vertical, diretamente da entidade de base (primeira figura a seguir); no sentido horizontal, a partir do perfil constituído do módulo cíclico (segunda figura a seguir). Em Parcours... o compositor aplica essas duas modalidades na terceira seção: a primeira, para fornecer as frequências que alimentam a constituição dos sons de síntese a partir da entidade de base, comprimida e expandida proporcionalmente de modo a resultar em aglomerados verticais (sincrônicos); a segunda, para elaborar os perfis da flauta a partir do perfil melódico principal, "comprimido" proporcionalmente de modo a resultar em figurações horizontais (diacrônicas) de igual contorno. E, na dinâmica da interação, estas caracterizações verticais e horizontais da flauta e dos sons de síntese se entrecruzam: os sons de síntese também "deslizam” para instituir relações horizontais; os sons da flauta são verticalizados gradualmente para formar aglomerados cada vez mais densos.

13 Falaremos mais a respeito da "cor" harmônica na análise de Altra voce. 
Figura 11 - Projeção proporcional da estrutura intervalar da entidade de base

Fonte: elaborada pelo autor

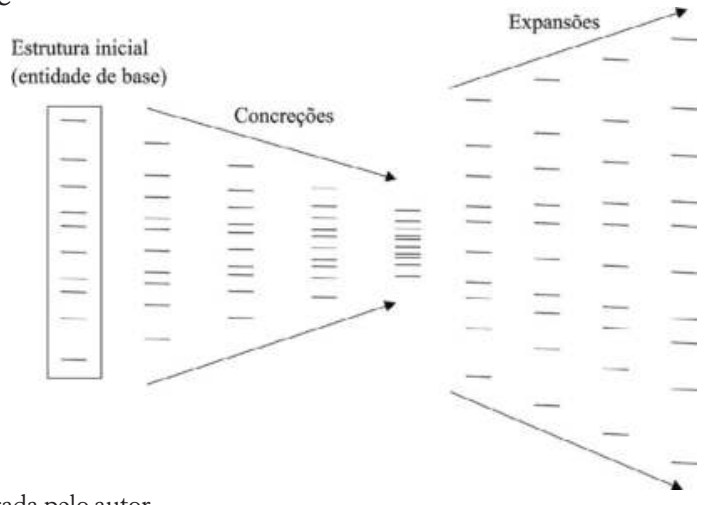

Figura 12 - Exemplo de concreção proporcional do perfil constituído a partir do módulo cíclico. De maneira análoga, também seria possível realizar expansões.

Estrutura inicial

(perfil principal, estruturado com a mesma

distribuição intervalar da entidade de base)
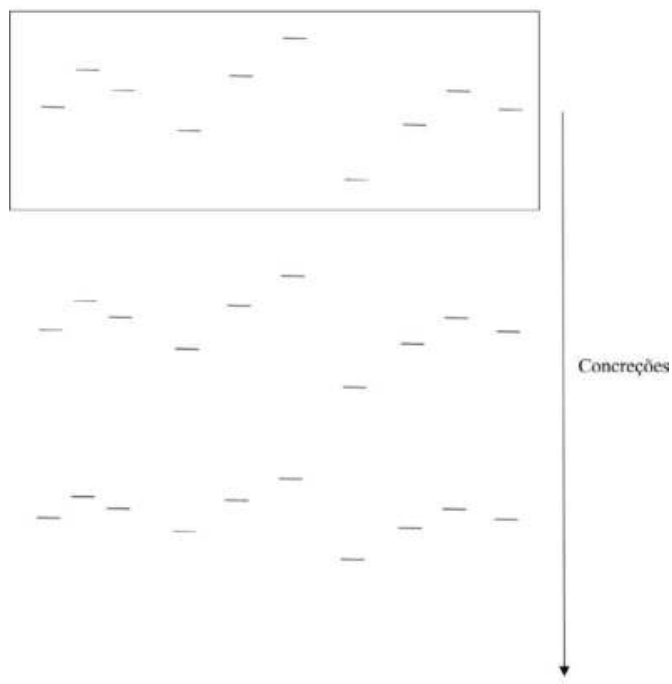

Fonte: elaborada pelo autor 


\section{Primeira seção formal (0" a 5'26")}

Da perspectiva de um modelo do som, das considerações da matéria sonora e sua correlação direta com o material, há já no momento inicial da obra alguns pontos fundamentais a considerar. A quebra de expectativa causada por uma conformação espectral encerra, sintomaticamente, a transição gradual e contínua de um ataque metálico a um som de flauta, os dois instrumentos essenciais de toda a composição. A dicotomia entre o "som de sopro" e o "som metálico" está, por sua vez, representada no corpo da própria flauta - encontra no som de "sopro" sua particularidade, sua proximidade ao som das madeiras, embora constituída de corpo metálico -, como se tornasse possível uma concepção de instrumento cujos sons subvertessem sua essência material, constituindo já um dado relevante para as deformações que serão realçadas pelos recursos eletroacústicos.

O primeiro elemento da obra (0" até 52") propõe um percurso entre o gesto inicial - som percussivo metálico oriundo de tratamento - e as transformações espectrais provocadas nos transientes de sustentação e extinção. Apesar do espectro inarmônico, o ataque inicial se estabiliza logo em seguida em um lá bemol 5, e a longa ressonância leva a uma transição para um som tônico (fundamental si bemol 5), transição que se dá por meio de um glissando: após atingir esta outra altura, observa-se o início de um batimento, seguido da extinção total do som. $\mathrm{O}$ ataque inicial é proveniente de um som de bigorna da obra Dialética da praia, de 1993. Este som foi sampleado com um Akai S1100, e foi em um DX-7-II (sintetizador clássico da Yamaha, ainda em uso no Studio PANaroma) que Menezes atuou com o pitch wheel para realizar o glissando. Paralelamente, foi adicionada reverberação ao som, o que, em seu transiente de sustentação, foi responsável pelo caráter de "sopro" que possibilitou sua transmutação eficaz (cross fade) ao som de flauta. ${ }^{14}$ A transferência espectral, operação que

14 Outro dado interessante sobre este som que abre a obra é que Menezes revela ter buscado escapar do universo metálico dos "sons de sinos" (bell-like), muito comuns à época da composição e utilizados em demasia na música eletroacústica (dados obtidos em entrevista do compositor pelo autor em 21 nov. 2011). 
permite transições sutis entre caracterizações espectrais ou, ainda, uma imitação propriamente dita de um modelo espectral (como uma imitação de um som instrumental para gerar outro som na esfera eletroacústica, conferindo relações estruturais entre ambos), constituirá um procedimento anamórfico típico na interação entre instrumentos e processos eletroacústicos: uma "anamorfose funcional", para voltarmos à terminologia de Schaeffer.

Este elemento inicial será então repetido com uma variação dinâmica entre 57" e 1'54" - ff em oposição ao $f$ do primeiro ataque, conforme indicado na camada eletroacústica da partitura -, o que intensifica o caráter inicial inarmônico do espectro e a maior amplitude no fenômeno posterior do batimento. Próximo à extinção do som, surge a flauta em dó ( $p p p)$ em uníssono com o "pedal eletroacústico"

Figura 13 - Sonograma do trecho inicial de Parcours de l'Entité

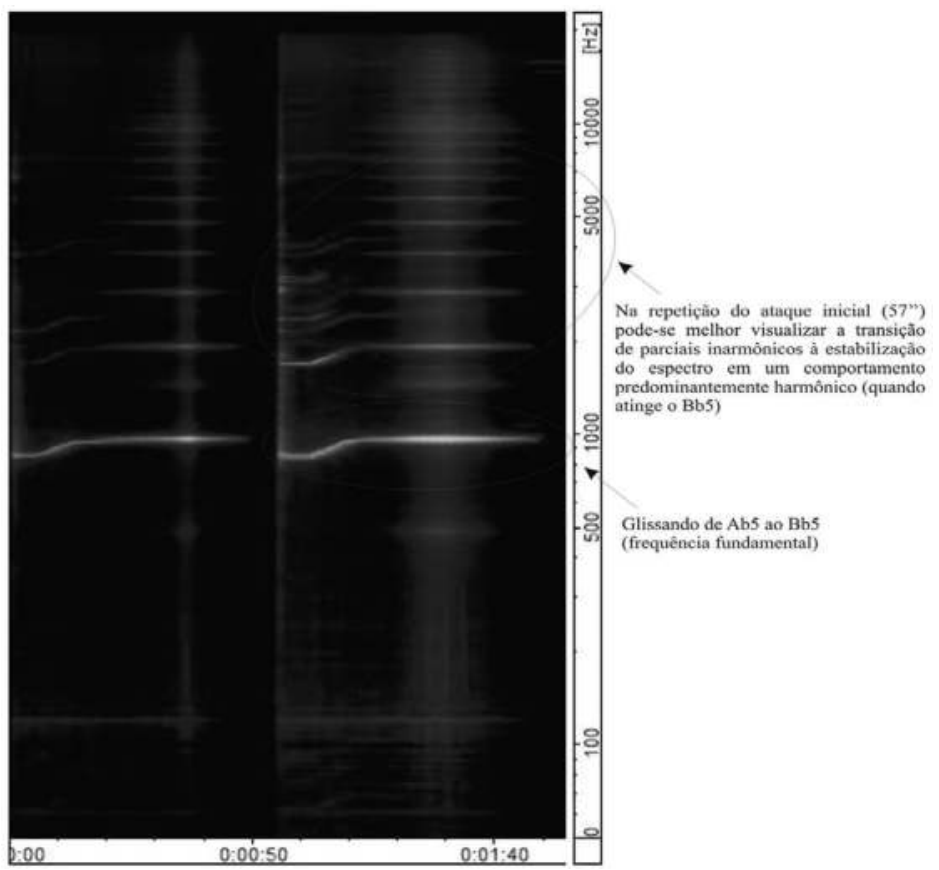

A figura evidencia a migração do lá bemol 5 ao si bemol 5 e a intensificação dinâmica na primeira repetição do ataque metálico aos 57" (ver Exemplo sonoro 1 - 0" a ca. 35").

Fonte: elaborada pelo autor 
formado pelo regime de sustentação do som percussivo (neste momento já transfigurado em som de flauta), em completa fusão espectral. A textura deste trecho é portanto homogênea e formada por sons contínuos.

É ainda notável que este glissando (variação de altura claramente perceptível, portanto perfil) no transiente de sustentação mascara o que poderia ser percebido exclusivamente como modulação de timbre, pela maneira como ocorre a gradual transformação do som, que muito lentamente passa do caráter metálico com uma percepção de altura preponderante (lá bemol) ao som tônico de flauta que estabiliza em si bemol. Fosse mantida a altura, a modulação de timbre seria evidente. No entanto, o som inicial como um todo abarca, por meio do glissando, tanto a mudança de coloração quanto o perfil, resultando no comportamento sonoro que Wishart denomina morfologia dinâmica. E a realização de um perfil, bastante alongado no tempo e permeando o transiente de sustentação, traz o cerne da dialética gesto-textura: "ilude" a escuta do ponto de vista do espaço espectral e torna menos evidente o processo interno de transformação do som, tornando-o mais fluido e imperceptível.

A partir de 2'08", após outro período de silêncio, inicia-se uma espécie de apresentação retrogradada do elemento inicial, em uma interessante transferência de um procedimento típico da escritura instrumental. ${ }^{15}$ A reintrodução do "pedal eletroacústico" logo em seguida à entrada da flauta ressalta dois estratos distintos. Além disso,

15 Aliás, muitas das indicações referentes ao estrato eletroacústico na partitura seguem modelos da escrita instrumental, como, por exemplo, as marcações de dinâmica e as notas relativas às frequências fundamentais dos polos harmônicos utilizados no estrato eletroacústico. Esta característica da escritura do compositor parece ser um dos pontos fundamentais para compreender a interação entre as esferas instrumental e eletrônica da obra, uma vez que não só os sons pré-gravados advém da instrumentação utilizada, como também alguns procedimentos de escritura eletroacústica se aproximam bastante das técnicas composicionais instrumentais, como a "retrogradação" mencionada acima a partir de 2'08", a distribuição de durações e o uso da técnica das projeções proporcionais para a determinação do espaço frequencial dos sons de síntese, que será visto adiante. 
suprimido o ataque, o enfoque da escuta se volta eminentemente à constituição espectral, fortalecendo a segregação com a flauta, antes “colada" ao estrato eletroacústico. Já em 2'19", outro ataque, seguido da entrada do percussionista, desvela a distinção de três elementos a partir do arquétipo de ataque-ressonância, fato marcado pelo início do percurso do flautista pelo palco em direção à posição 2. Observa-se, então, que cada um desses três elementos começa a ser desenvolvido: o ataque percussivo metálico é a partir daqui transferido a outros ataques na esfera instrumental, ${ }^{16}$ com diversas intensidades e timbres (diferentes instrumentos de percussão); a flauta realiza perfis melódicos a partir de 2'25”, o que pode nos sugerir alguma referência à variação de frequência apresentada inicialmente por meio do glissando; e o som contínuo ("pedal eletroacústico") é mantido como resultado da valorização do transiente de sustentação do som inicial. O que ouvimos antes como o prolongamento de um gesto de ataque agora definitivamente se decompõe em três camadas distintas.

Como será visto ainda, a mudança de flautas, em geral, representa pontos de articulação importantes na peça, não somente pelo contraste timbrístico, mas pela intervenção direta no espaço - entendido em sua dimensão sonora e sua dimensão cênica. Com efeito, a

16 Esta analogia entre os materiais instrumentais e eletroacústicos, em seus diversos níveis de interação, também responde pela possível instauração da ilusão no jogo entre os próprios materiais. A transferência é descrita no artigo "Por uma morfologia da interação": "As transferências estruturais podem apoiar-se em aspectos outros que não a coloração (timbre) dos espectros, tais como relações de identidade em frequência, em percurso espacial, em comportamento dos perfis melódicos e de massa, em constituição gestual dos sons (que podem identificar-se até mesmo pela forma de tratamento aos quais se submetem). Ou seja: ainda que seja mais condizente com a fusão partir dos próprios sons instrumentais para a elaboração dos sons eletroacústicos, o uso de outras fontes sonoras não implica necessariamente inviabilidade de fusão e pode, em contrapartida, viabilizar a transição que vai do fundido ao contrastado. Será, pois, pelo viés de tal distinção relativa - apenas possível, no caso de se utilizarem os mesmos sons instrumentais na elaboração dos sons eletroacústicos, após inúmeros procedimentos de transformação do material de partida - que a edificação de toda uma gama de distanciamento tornar-se-á possível, até que se atinja o contraste mais evidente, com ausência de qualquer transferência espectral" (Menezes, 2006, p.386). 
entrada da flauta-baixo em dó a 2'50" prenuncia um novo elemento fundamental que adentra a camada de escuta da flauta: o elemento "sopro", marcado pela movimentação do flautista no palco da posição 2 à 3 . E é com a emergência deste elemento que a flauta definitivamente se aparta dos espectros metálicos iniciais, pois é com o sopro que ela "sintetiza" sua diferença com os instrumentos de percussão metálica. ${ }^{17}$ "A obra direciona-se, a rigor, à liberação de energia presente no gesto musical que consiste no sopro quase afônico através do tubo da flauta" (Menezes, 1998, p.83). Apesar de este gesto causar um grande impacto na escuta, sua constituição espectral com forte "dispersão" frequencial advinda do ruído do sopro é bastante distinta dos materiais produzidos até então pela flauta. Além disso, encerra um aspecto relacional com o ataque metálico que abre a peça: é como se o sopro ampliasse temporalmente aquele gesto inicial, como se representasse o resultado de um processo de dilatação ou "alongamento" do golpe metálico.

O elemento "sopro" é então desenvolvido e valorizado gradualmente em relação aos demais: ele trará, no ápice de seu desenrolar, pouco tempo depois (3'19,5'), uma clara referência gestual ao ataque abrupto do início (além da possível comparação em termos de constituição espectral mencionada anteriormente), porém em um registro bem mais grave e marcado pela confirmação de um novo polo harmônico: em oposição ao si bemol que era ouvido no pedal eletroacústico, há uma movimentação gradual em direção ao dó, que havia surgido no pedal eletroacústico em 2'31" (como veremos adiante, este polo é enfatizado paralelamente nos perfis da flauta). A direcionalidade ao gesto do "sopro" é atingida, pois, por meio desta gradual mudança da constituição espectral ao registro grave; as entradas dos instrumentos percussivos na peça confirmam a direcionalidade de registro: início com triângulos e crotales bastante agudos; seguem-se então triângulos e crotales graves; cloche-plaque;

17 Esta problemática envolvida nos usos dos recursos instrumentais da obra seria retomada três anos depois em ATLAS FOLISIPELIS, que aborda a dualidade do sopro ("folis", representado pelos oboés) com as "peles" da percussão. 
gongos tailandeses e coreanos, até que em 3'35" surge o ataque mais grave, de um gongo tailandês, logo após o "sopro" se impor no elemento "pedal":

Figura 14 - Movimento direcional na percussão em Parcours...

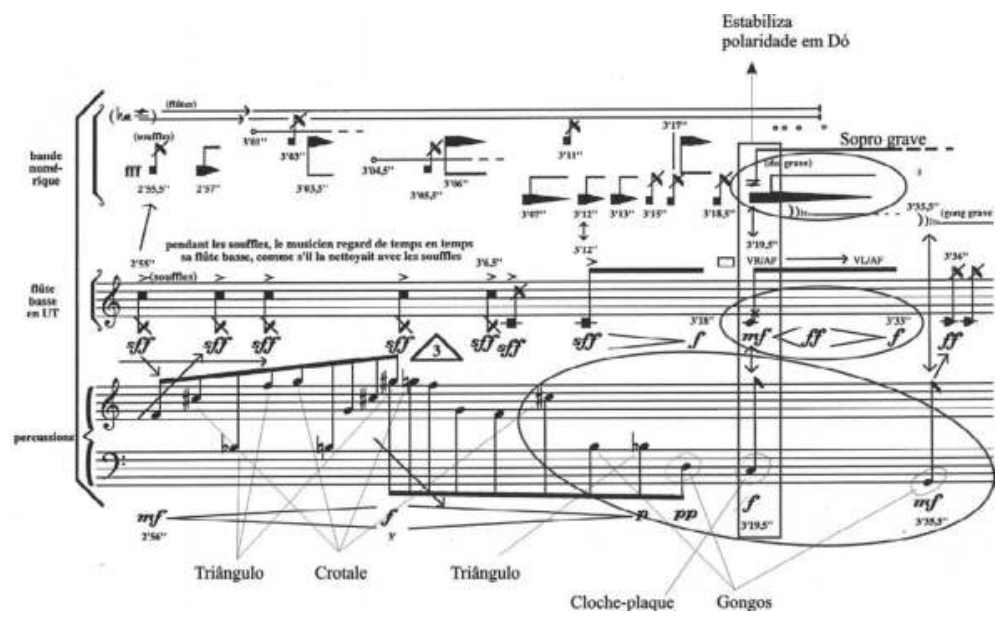

Atinge-se o limite grave do registro do corpo instrumental percussivo com o gongo tailandês em 3'35", logo após o ataque simultâneo da cloche-plaque grave, flauta-baixo e do "sopro" em dó. Repare que, logo após o ataque conjunto em 3'19,5”, cessa o si bemol do "pedal eletroacústico".

Fonte: comentários do autor sobre Menezes (1998, p.2)

Um alargamento da espessura do espectro inarmônico provocado pela percussão também desestabiliza o si bemol; aqui, mais uma vez ocorre, em um nível mais amplo que engloba três camadas de escuta, algo similar ao que analisamos no início da obra: à mudança progressiva do polo harmônico (agora de si bemol para dó, também um salto de segunda maior, assim como no ataque que abre a peça) observa-se simultaneamente uma transformação significativa da constituição espectral. Neste caso, no entanto, a movimentação de segunda maior é por demais gradual e menos percebida como perfil; a flauta também cessa os perfis após a entrada do elemento sopro (ver figura anterior), alterando a característica da segunda camada de escuta; os ataques percussivos sucessivos em diferentes registros, 
por apresentarem uma distribuição bastante "pontilhista", por assim dizer, também reduzem a percepção de perfis a um acúmulo de ressonâncias referente ao alargamento de espessura nesta terceira camada de escuta.

Ao atingir e estabilizar o registro grave, o flautista parte então para outro trecho de seu "percurso" (posição 3 à 4), e com um glissando prenuncia o retorno da realização de perfis melódicos, que haviam sido interrompidos quando da introdução do elemento sopro.

Em 4'26", a movimentação do flautista (posição 4 à 5) marca, mais uma vez, o surgimento de um elemento diferenciado: os sons "iterados", que terão grande importância na segunda seção formal. Aos 4'39”, o elemento pedal identificado no início da peça ressurge bastante diferenciado, como que incorporando e fundindo o caráter "rugoso" do elemento sopro, em mais um procedimento relacional de transferência variada do material constitutivo de um objeto sonoro a outro. Neste trecho, há uma desestabilização do polo de dó e imediatamente ouve-se uma polarização do lá bemol, em um retorno à altura ouvida no início da obra.

Para descrever o percurso do material harmônico ao longo da peça, apoiar-nos-emos em alguns pontos de articulação que se apresentam como fortes indícios à escuta para as transformações que seguem. Esses pontos de articulação compreendem, por um lado, os contrastes entre som contínuo e saltos; por outro, as modificações de registro, polos harmônicos e a apresentação de novos materiais. Permeando esses aspectos, encontram-se os gestos cênicos.

Conforme a figura seguinte, é apresentada a terceira retrotransposição do módulo cíclico pela flauta no início da seção. Já havíamos comentado anteriormente que em ca. 2'50" há um importante ponto de articulação na peça: o flautista se move para a posição 2 no pal$\mathrm{co}$, troca de instrumento (agora com a flauta-baixo) e segue-se um novo trecho (uma espécie de subseção) que enfatiza a mudança de registro por meio de um elemento bastante gestual: o "sopro". A mudança gradual do eixo de polarização harmônica de si bemol a dó ocorre no estrato eletroacústico - é possível observar, em 2’31”, um pedal em dó paralelo ao si bemol - e também nos perfis melódicos 
da flauta desde seu início em ca. 2'24”. À parte todos os fatores já descritos sobre a desestabilização do eixo de si bemol, atentaremos momentaneamente ao ponto de vista da polarização harmônica ${ }^{18}$ na constituição dos perfis melódicos.

Figura 15 - Módulo cíclico no início de Parcours...
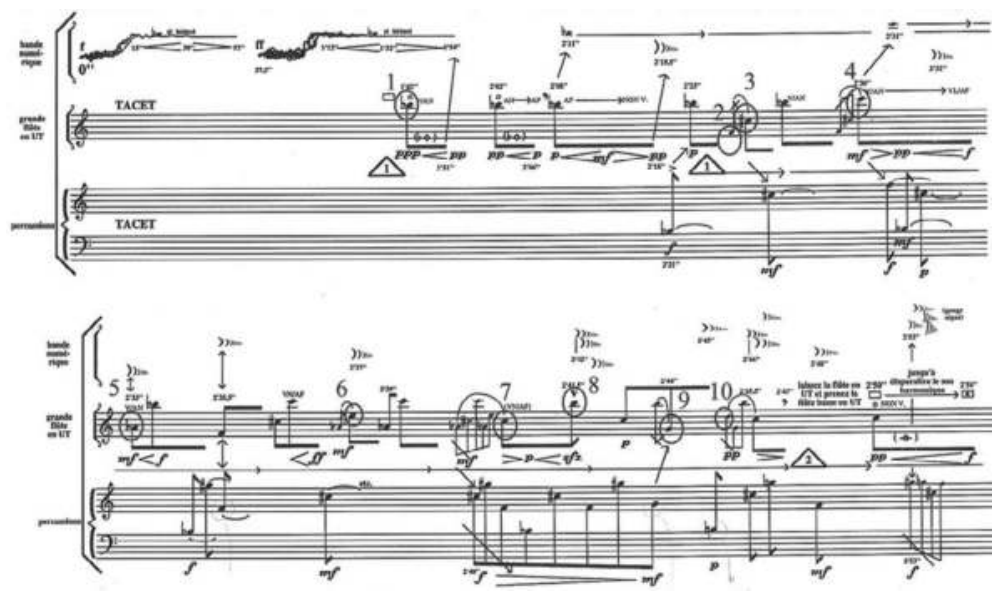

Todas as alturas utilizadas para a flauta (excluindo-se suas repetições) correspondem ao retrógrado da terceira retrotransposição da entidade de base.

Fonte: comentários do autor sobre Menezes (1998), página 1 da partitura

18 O termo polarização, comparável à noção de atração, repulsão e neutralização presente tanto em estudos moleculares quanto de campos eletromagnéticos, encontra na acústica musical grande fundamentação teórica em Edmond Costère: "O termo polarização - presente de forma explícita em Costère principalmente em seu verbete sobre o vocábulo na Encyclopédie de la Musique da Fasquelle (cf. Costère, 1961, p.460-461) - e até mesmo conceitos deste derivados, tais como bipolaridade, multipolaridade ou onipolaridade, estão enfaticamente presentes no principal escrito de Henri Pousseur sobre harmonia, 'L'Apothéose de Rameau - Essai sur la Question Harmonique' (Pousseur, 1968, em especial p.114). [...] As designações 'intervalos polares', 'neutros' ou 'apolares', ainda que encontrando plena sintonia com o legado teórico de Costère, derivam sobretudo de sua aplicabilidade composicional no Brasil através, principalmente, dos ensinamentos de Willy Corrêa de Oliveira em São Paulo, o quê se deu após Willy ter conhecido pessoalmente Pousseur e Berio em Darmstadt no início dos anos 60" (Menezes, 2002, p.103-4). Muito resumidamente, os intervalos polares no âmbito da oitava são a 4J, 5J, 2m e 7M; os neutros são as terças e sextas; os apolares a $2 \mathrm{M}, 7 \mathrm{~m}$ e o trítono. 
É extremamente sintomático o uso da terceira retrotransposição na composição dos perfis da flauta do ponto de vista da polarização harmônica: de dez notas, seis são polares de dó e apenas três são polares de si bemol; além disso, as duas notas centrais da retrotransposição são neutras a dó, porém apolares a si bemol, fortalecendo ainda mais a direcionalidade ao novo eixo harmônico (ver figuras $\mathrm{A}$ e $\mathrm{B}$ a seguir; repare na presença destas notas no trecho da partitura mostrado na Figura C). É particularmente interessante que a simetria proveniente da distribuição intervalar da entidade de base se aplique também com relação aos polos de dó na retrotransposição 3: si bemol e ré nos extremos (apolares); duas notas neutras ao centro; três notas polares de cada lado do eixo de distribuição de notas (Figura A).

No trecho da partitura colocado na figura C evidencia-se a preponderância de um conteúdo harmônico mais próximo a dó que a si bemol, centrando nos perfis da flauta um importante fator da direcionalidade harmônica que culminará no referido "sopro". Embora a entrada dos perfis na flauta a ca. 2'24" tenha introduzido notas polares tanto a si bemol quanto a dó (fá e si, notadamente), sugerindo certa dubiedade de polos no princípio, o desenrolar da terceira retrotransposição marcará de vez a "soberania" de dó.

Após a mudança do principal polo harmônico de si bemol a dó, a flauta-baixo desenvolve e enfatiza o gesto do sopro, eminentemente constante em altura (percepção de dó, sem perfis), para em seguida voltar a realizar pequenos contornos melódicos (3'57”). Vale notar que este contraste entre som contínuo e salto é enfatizado pelo elemento cênico: o flautista se move à posição 2 precisamente quando dá origem aos perfis a ca. 2'24”, onde toma a flauta-baixo para introduzir o "sopro"; vai à posição 3, onde estará situado durante a estabilização do novo polo harmônico; sai rumo à posição 4 no momento que antecede a retomada dos perfis a 3'57'. Nesta última mudança, o material harmônico corresponde à retrotransposição 1, e cada nota é introduzida de acordo com a ordem que ocupa originalmente. Este trecho vai até aproximadamente 5'21”, o final da primeira seção. Aqui, outra vez é revelada a escolha do material harmônico para a composição dos perfis: a retrotransposição 1 apresenta um 
Figura 16 - Polarização de dó na terceira retrotransposição de Parcours... (Figura A); polarizações de dó e de si bemol (Figura B); trecho correspondente da flauta na partitura, logo após o início da realização de perfis a ca. 2’24” (Figura C)
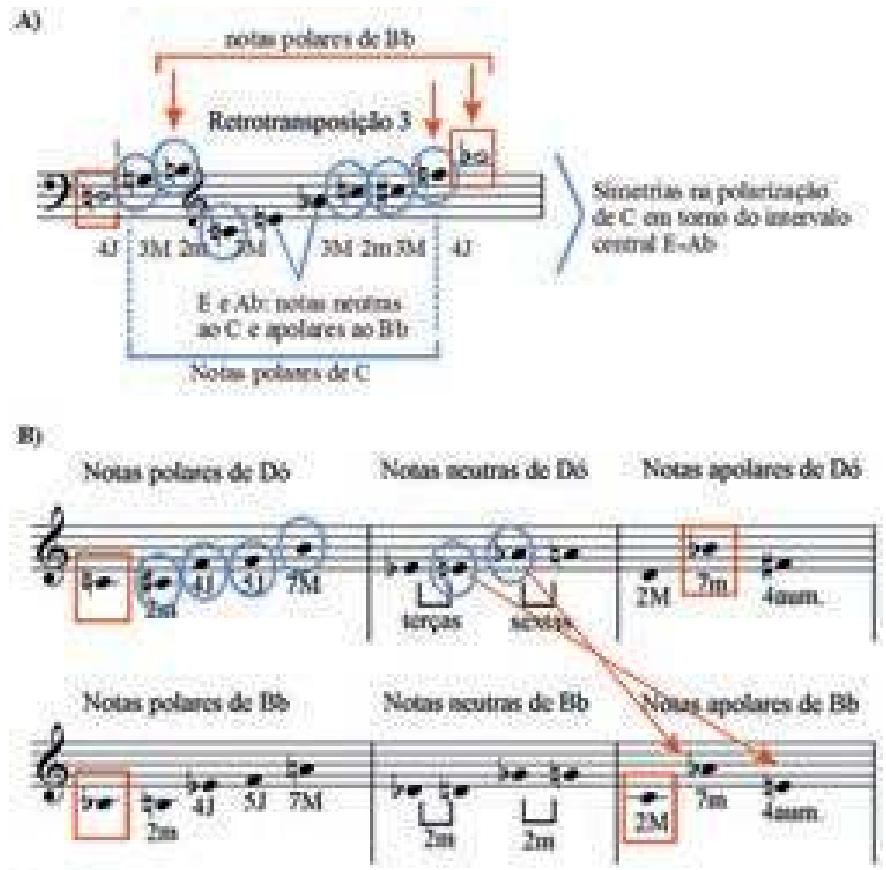

9

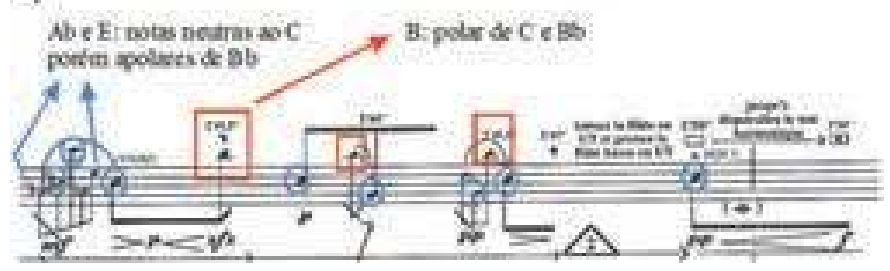

Fonte: (c) Menezes, 1998 (partitura, p.1)

maior número de notas polares de lá bemol, reforçando a tendência de retorno ao polo que se confirmará no início da segunda seção formal, em um processo que retoma a altura fundamental do gesto que abre a peça. É mantida ainda a mesma estrutura simétrica de 
polarizações: duas notas apolares nos extremos ( $\mathrm{Bb}$ e F\#), três notas polares de cada lado do eixo simétrico (Eb, G e Ab; Ab, A e C\#) e duas neutras ao centro ( $\mathrm{C}$ e E).

Figura 17 - Distribuição de polarizações na primeira retrotransposição

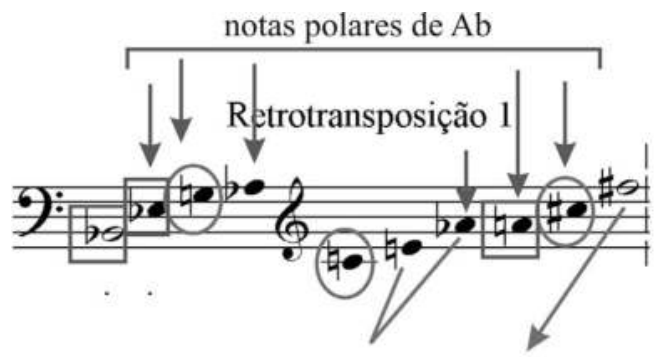
Ab e E: notas neutras ao C
$\mathrm{F} \#$ : neutra ao $\mathrm{Bb}$ porém apolares de $\mathrm{Bb}$ porém apolar de C

Note-se que são mantidas as mesmas simetrias de polarização ao lá bemol. Fonte: elaborada pelo autor

Do ponto de vista das durações, uma menção interessante pode ser feita ao ataque inicial, posto que se aproxima de um método organizativo muito comum em Menezes, qual seja, o uso da série de Fibonacci. ${ }^{19}$ As distribuições temporais seguem um curso curioso: do início ao final do glissando passam-se 15”, seguidos pela sustentação no polo de si bemol que, aos 38", atinge seu ápice em intensidade. Na repetição deste elemento, o pico de intensidade ocorre em 1'32" (o percurso do ataque ao fim do glissando mantém-se em 15"), aproximando-se muito de uma constituição fibonacciana: 15 " +38 " $=53$ "; $38 "+53 "=1$ '31". Buscando ainda o próximo valor desta progressão de durações, chegamos a 53"'+1'31"'=2'24", praticamente coincidente com o início da realização de perfis na flauta:

19 Série matemática cujo princípio formador é que cada termo se iguala à soma de dois precedentes $(0,1,1,2,3,5,8,13$ etc.). 
Figura 18 - Proximidades da organização das durações de eventos com a estrutura da série de Fibonacci no início de Parcours de l'Entité

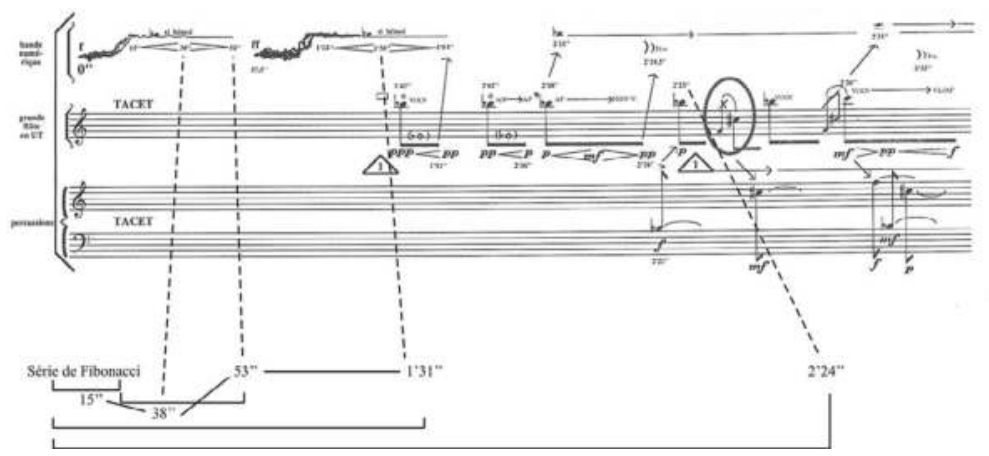

Fonte: comentários do autor sobre Menezes (1998, p.1, partitura)

\section{A segunda seção formal (5'26" a 7'33")}

O início da segunda seção é marcado pela mudança da flauta-baixo para a flauta-contralto em sol, além de contar com uma textura composta por elementos iterados (ou, genericamente, uma textura granular). Embora no início a flauta enfatize continuamente o lá bemol - reiterado pela presença dos trêmulos -, esta seção será fortemente caracterizada pelo desenvolvimento e expansão dos perfis melódicos. Desta forma, existe um grande contraste do ponto de vista textural: em oposição à textura eminentemente contínua da primeira seção, percebemos agora mais as qualidades granulares, como "movimentos de partículas". Em relação aos materiais, portanto, uma distinção radical emerge: a flauta, apesar de realçar o elemento "perfil", realiza contornos bem mais complexos; a dimensão eletroacústica não aponta quaisquer polos harmônicos e apresenta sons processados provenientes do material instrumental pré-gravado desta seção, alternando entre ruídos e contornos adirecionais de sons complexos.

Neste ponto, um aspecto importante da poética do compositor é responsável por mais um modelo para a interação entre esferas instrumental e eletroacústica: a elaboração secundária. Uma 
característica comum nos procedimentos composicionais de Flo Menezes é a tendência à exploração máxima do material (atitude, de fato, maximalista), ${ }^{20}$ sua manipulação à exaustão - não propriamente a um "esgotamento", posto que promove tal "abertura" do material que o veste de comportamentos até mesmo mais distantes de sua origem, imprevisíveis até que se o submeta a prova, não permitindo circunscrever este espaço de transmutações do material a algo esgotável.

Da mesma maneira como as técnicas harmônicas de Menezes tendem à especulação profunda acerca da entidade harmônica, a elaboração secundária busca retrabalhar estruturas já compostas por meio de processamento no estúdio eletroacústico. No caso da segunda seção formal de Parcours..., primeira aplicação deste procedimento na trajetória do compositor, partiu-se do trecho instrumental escrito equivalente e processado em estúdio - o material de percussão e flauta é transposto, via sintetizador DX-7, a diferentes campos de alturas, ${ }^{21}$ para gerar outras estruturas eletroacústicas presentes na obra. Assim, a elaboração secundária reflete um processo de escritura eletroacústica, em que o compositor parte de estruturas já realizadas e pratica outras transformações a partir delas, criando outras estruturas. A origem comum do material a partir dos instrumentos cria, pois, uma complexidade de perfis na dimensão eletroacústica que reflete, de forma equivalente, os contornos mais "elusivos" da flauta e da percussão, fortalecendo o modelo de interação.

Há uma direcionalidade a um perfil melódico principal na flauta que surgirá na terceira seção formal. Portanto, a expansão do material harmônico (via módulos cíclicos, conforme será visto posteriormente) e a maior complexidade dos perfis nesta seção não são casuais.

20 Termo cunhado por Menezes em 1983 para a música especulativa, "por antítese ao minimalismo e às tendências popularescas” (Menezes, 2006, p.306).

21 Em Colores (2000), Menezes utiliza o final de Harmonia das esferas (também de 2000) e cria oito pistas simultâneas com trajetórias específicas, designando novas amplitudes a cada uma de modo a construir um espaço sonoro complexo. Fonte: entrevista com o autor em 21 nov. 2011. 
Na mudança da flauta-baixo para a flauta-contralto em sol há referência ao eixo de lá bemol reiterado com o uso dos trêmulos. De maneira análoga ao início da obra, quando um salto de F-C\# na flauta rompe o longo trecho formado por "alturas constantes", o intervalo de sexta menor ressurge em 5'36" (C-Ab escritos, soando $\mathrm{G}-\mathrm{Eb}){ }^{22}$ recontextualizado pelos trêmulos. Em relação ao conteúdo harmônico, há uma intercambialidade entre as alturas das três retrotransposições (existe, no entanto, uma referência à escuta promovida pela recorrência de intervalos). A cerca de 5'50" (final do perfil mostrado na figura a seguir), ouve-se claramente a sexta menor descendente Ab-C. Ouvem-se também, de maneira mais velada devido às rápidas sucessões de alturas, segundas, quartas e terças alternadas (e suas inversões), iniciando um processo de "desvelamento" do perfil principal que será apresentado na última seção. Veremos, posteriormente, que as durações terão papel fundamental nesse "desvelar" do perfil por meio de uma desaceleração nas sucessões de alturas.

Figura 19 - Flauta em sol (soando uma quarta abaixo do escrito) entre 5'45" e ca. 5'53"

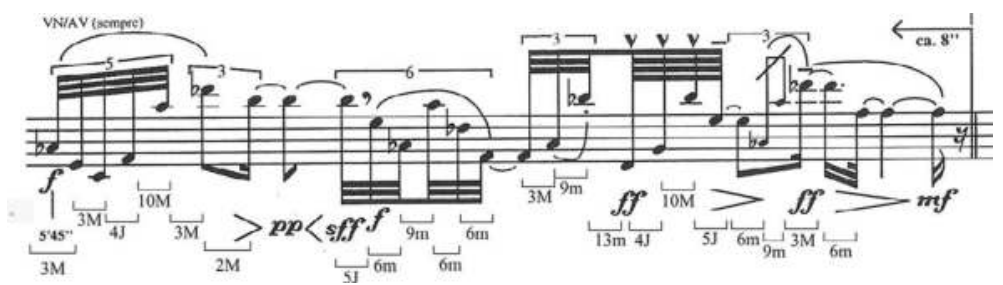

Perfil melódico apresentado no início da segunda seção, contendo notas das três retrotransposições, mas já apresentando uma estrutura intervalar mais próxima ao perfil principal. Nota-se a presença, pela primeira vez, da décima terceira menor enfatizada com um $f f$ na segunda nota (salto descendente do Bb a D, soando F-A), importante intervalo do perfil principal e, ao final, o $\mathrm{Db}-\mathrm{F}$ descendente (soando $\mathrm{Ab}-\mathrm{C}$ ) que equivale à $13 \mathrm{~m}$ do perfil principal (ainda que aqui estejam dispostos em uma $6 \mathrm{~m}$ ).

Fonte: comentários do autor sobre Menezes, 1998 (partitura)

22 A expansão deste intervalo $(13 \mathrm{~m})$ constitui o eixo central do perfil melódico principal elaborado para a flauta. 
A partir de ca. 5'50", as alturas utilizadas provêm da retrotransposição central, explorada exclusivamente pela primeira vez; aqui, no entanto, há uma exposição das notas que não obedece à ordem original. Observa-se, como procedimento, uma divisão ao meio da segunda retrotransposição, enfatizando a sexta menor central C-Ab. No trecho entre 6’32" e 6’45”, embora a elaboração dos perfis torne-se mais complexa, as notas utilizadas passam a orbitar constantemente este intervalo no curso da seção, apresentando à escuta a dualidade entre percepção de intervalos propriamente ditos e contornos. Aqui, como pode ser visualizado na figura seguinte, há outro processo interessante de simetrias na flauta - agora do ponto de vista da densidade de notas - paralelo a um direcionamento ao registro grave, direcionamento este análogo ao que ocorreu na primeira seção antes da polarização de dó.

Figura 20 - Página 5 da partitura: simetria em relação ao si bemol (soando fá) na flauta, paralela à direcionalidade geral ao registro grave

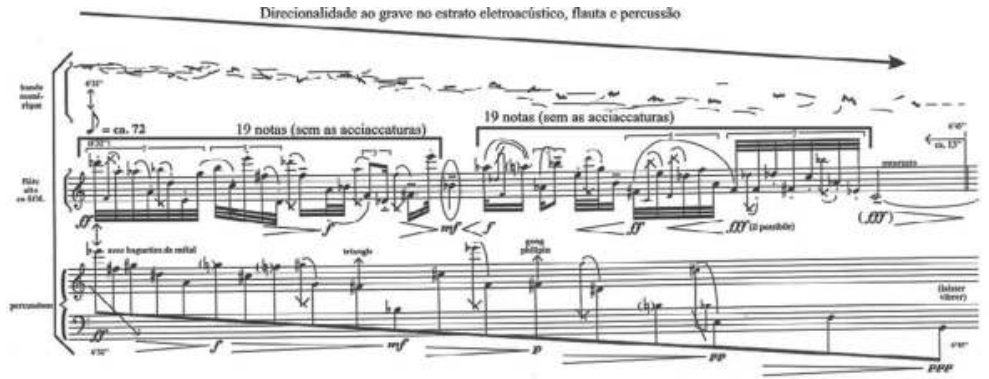

Fonte: comentários do autor sobre Menezes (1998), partitura

A movimentação ao registro grave é utilizada de forma recorrente pelo compositor: na entrevista realizada em novembro de $2011 \mathrm{com}$ o autor, ele ressalta a direcionalidade ao grave como um "fundamento espectral para repousar a escuta", algo encontrado com frequência, segundo Menezes, nas obras para piano de Brahms op.116 a 119. 


\section{A transição (7'37" a 8'38")}

O final da segunda seção é marcado pela rarefação da textura granular, pontuada por longos silêncios. Nesta transição, o flautista, que não se movimentava pelo palco desde a primeira parte da peça, percorre seu caminho rumo à posição 6 (retorno da flauta em dó). $\mathrm{O}$ trecho congrega, de maneira bastante sintomática, os dois principais gestos da obra até o momento: o ataque-ressonância proveniente do som metálico inicial - desdobrado no elemento "pedal" e em golpes metálicos nos estratos instrumental e eletroacústico - e o "sopro" da flauta. Em claro contraste com a segunda seção, os sons são eminentemente contínuos e quase não há referências a perfis melódicos (glissandos ou saltos intervalares).

Com a rarefação da textura, tem-se máxima fusão espectral nas duas camadas de escuta presentes inicialmente (de 7'37" a 8'19,5”): "pedal" - reposicionamento do eixo sobre si bemol em ambas esferas (flauta e eletrônica) - e "ataque metálico" - alternância e simultaneidade de golpes na percussão e por via eletrônica. Ao final da transição, ressurge o elemento "sopro" - variado pela alternância da oitava com o som original -, cujas curtas durações anunciam uma nova "acumulação energética", um aumento de tensão, culminando com o estiramento temporal deste mesmo elemento, a "liberação de energia" do longo sopro grave que demarca, juntamente a outros fatores ainda a serem explorados, o despertar da terceira seção.

\section{A terceira e última seção formal (8'38" a 15'41")}

Mais uma vez, o gesto cênico marcará um ponto estrutural importante na obra: o início desta seção, quando o flautista atinge a posição 7. Paralelamente, o percussionista realiza um gesto exagerado antes de atacar, simultaneamente, gongo tailandês e cloche plaque, mas em seguida subverte a relação causal presente no gesto instrumental percutindo em $p p$ (resultado sonoro em $p p$ ). Estas ações indicadas na partitura prenunciam a "abertura" que ocorre 
no domínio dos materiais utilizados - busca por "novos territórios" do espaço harmônico via projeções proporcionais, gerando perfis não temperados na flauta e as frequências para a constituição dos espectros dos sons sintetizados, introduzidos pela primeira vez no início desta seção. No trecho em questão, a dimensão eletrônica de síntese delimita oito segmentos contínuos discriminados na partitura como Music V1 a Music V8, em referência ao programa de síntese utilizado, ${ }^{23}$ tendendo a deslocar o enfoque da escuta nesta camada para a constituição dos espectros.

É curioso notar que este aspecto do enfoque nas constituições espectrais do estrato eletroacústico ressoa na percepção espacial dos sons, estabelecendo uma intrincada rede de possíveis significados entre o espaço frequencial e o espaço da performance: o comportamento dos sons de síntese contribui para uma ampliação da estereofonia no espaço, criando defasagens e campos de "profundidade" mais pronunciados, possibilitando uma correlação com a mobilidade do flautista no palco. Esta percepção é intensificada com uma intervenção direta no espectro que o compositor realiza a partir do som Music V6: a aparente mobilidade de parciais. São aplicados processos de defasagem aos parciais que, além de conferir maior mobilidade geral ao espectro, intensificam a sensação de relevo sonoro, apesar de partirem exclusivamente de dois canais.

Exemplo sonoro 10 - Trecho a partir de 11'40" de Parcours de l'Entité ${ }^{24}$

Consolidando o início desta nova situação, o percussionista deve permanecer imóvel até o final da obra: após a apresentação dos principais elementos gestuais das duas primeiras seções da peça (sopro e ataque metálico logo ao início da seção), a imobilidade física do

23 Referência ao clássico programa de computador para síntese sonora Music V (a partir do Music I, II etc. criado em 1957 nas dependências da Bell Labs pelo norte-americano Max Matthews).

24 Disponível em: <https://soundcloud.com/tiago-gati>. 
percussionista atua como se o intérprete cedesse o espaço de sua presença (causalidade) ao universo da constituição espectral dos sons de síntese; estes, apesar disso, foram elaborados com base em sons tipicamente "instrumentais" - inicialmente realizados no Centro di Sonologia Computazionale de Pádua com assistência de Andrea Provaglio, provenientes da síntese de gongos do catálogo de Jean-Claude Risset. ${ }^{25}$

Juntamente com os longos segmentos contínuos mencionados (Music V 1 a 8) nota-se, gradualmente, o surgimento de "perfis eletroacústicos" próximos aos realizados pela flauta (com material harmônico equivalente, como que a "imitando"), precisamente quando o perfil melódico principal é atingido a 10'50” (referente ao som Music V5).

Em ca. 15', cessam-se os perfis e retorna a fusão entre universos eletroacústico e instrumental por meio do uníssono no mesmo si bemol 5 do início da peça. Assim como a seção de transição havia reunido elementos gestuais caros às duas primeiras seções, o final da obra ressalta o "pedal" agudo de si bemol, agora como referência textural e, enfim, o "sopro", elemento gestual de fundamental importância ao longo de toda a peça. Neste último gesto, a questão do desvio na causalidade instrumental é novamente abordada por meio do desempenho cênico do flautista, que somente representa a ação instrumental em silêncio (conforme indicado na partitura). Curiosamente, a liberação de energia presente neste gesto musical tipicamente instrumental é concretizada em sons pela dimensão eletroacústica: ou seja, o som de sopro que ouvimos provém dos alto-falantes, mas na performance vemos o flautista realizar a ação correspondente.

25 Os sons sintéticos utilizados no catálogo do compositor francês Jean-Claude Risset "podem ser recriados por qualquer um que tenha acesso ao programa de síntese Music V. O usuário pode 'desviar' dos modelos e parâmetros empregados por Risset para criar sua própria versão dos sons” (Beauchamp, 1971, tradução livre). Com efeito, Menezes utilizará as projeções proporcionais para determinar a distribuição frequencial dos sons de síntese. 
Marcando o contraste que abre a terceira seção com os sons contínuos da transição, quando o flautista se movimenta a duas posições distintas em apenas um minuto, surge o uso das projeções proporcionais. Esta técnica almeja, como bem o revela seu nome, outras proporções harmônicas com base em uma estrutura intervalar inicial, sejam esses novos pontos temperados ou não. Serão tomadas como base duas estruturas para a aplicação da técnica: a entidade de base, com quatro concreções e três expansões da estrutura vertical, com a finalidade de obter as frequências utilizadas nos sons sintéticos, e o perfil principal, com quatro concreções utilizadas na elaboração dos perfis da flauta.

\section{As projeções proporcionais na elaboração dos sons de síntese}

Para a realização desses novos espaços harmônicos "proporcionais", pode-se fazer uma analogia com a divisão logarítmica da escala temperada: $\sqrt[12]{2}=1,0594$, correspondente ao fator que, multiplicado a uma dada frequência, resulta em uma outra um semitom acima. No caso do cálculo das projeções, são usados os intervalos internos que constituem a entidade de base dois a dois - partindo-se do intervalo central e irradiando a ambas as frequências extremas -, sendo cada intervalo extraído da entidade um novo âmbito. Insere-se proporcionalmente dentro dele toda a estrutura intervalar de origem: quando este intervalo é menor que o âmbito extremo original, há compressão; do contrário, há expansão. Em Parcours..., além do âmbito entre a nota mais grave e a mais aguda da entidade, Flo Menezes dá sequência à constituição simétrica da estrutura, realizando mais três expansões que são adicionadas a quatro concreções (figura seguinte). ${ }^{26}$

26 As sete projeções proporcionais como material de base aos sons sintetizados, conforme já havia sido antecipado, são apresentadas sequencialmente na partitura, indicadas como Music V1, Music V2, Music V3 etc. Esta maneira de abordar a entidade de base, propagando-a a partir de sua estrutura interna (constituição intervalar), prenuncia o que Menezes mais tarde designará por “propensão harmônica” (ver Menezes, 2006 e 2013). 
Figura 21 - Novos âmbitos utilizados para o cálculo das sete projeções proporcionais utilizadas na constituição espectral dos sons de síntese

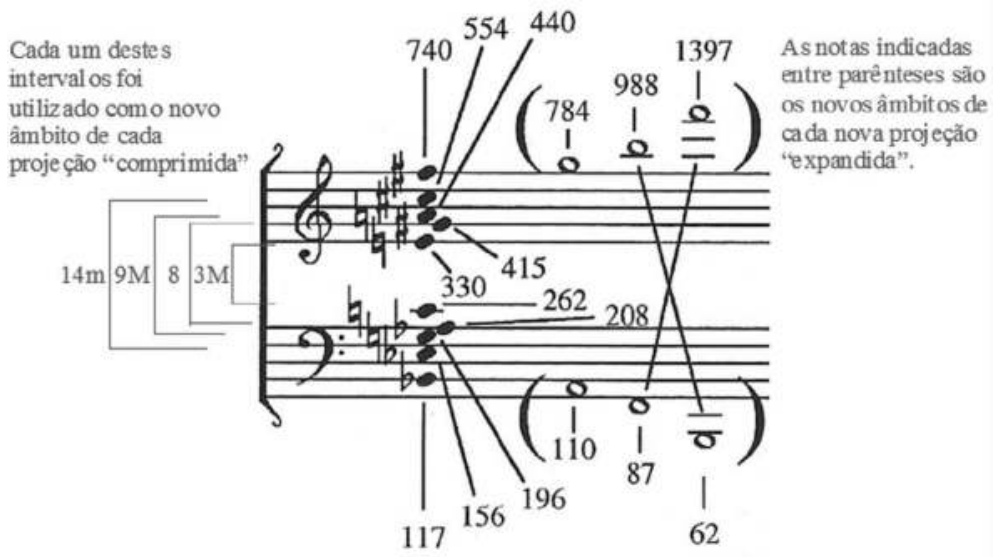

Cada novo âmbito é calculado pela razão entre as duas frequências selecionadas como extremos - indicadas acima em Hertz (o âmbito $\mathrm{Bb} / \mathrm{F} \#$ é a própria entidade de base): quatro acabam por comprimir toda a estrutura nos intervalos mostrados à esquerda; três resultam nos intervalos tais como demonstrados à direita (novos extremos entre parênteses). As expansões foram extraídas da organização promovida em ...Ora.., obra inacabada para orquestra. Fonte: comentários do autor sobre Menezes (1998)

Para tanto, é necessário calcular um passo intervalar equivalente ao semitom no sistema temperado, redistribuindo as frequências dentro desse novo âmbito. O cálculo pode, a partir da formulação mencionada acima para o temperamento, ser generalizado a $\sqrt[y]{X}$ :

$X$ - novo âmbito (nova razão entre o intervalo formado pelas notas extremas da entidade de base - no temperamento, esta razão é 2);

$y$ - quantidade de vezes em que se repete a unidade da subdivisão mínima de base, ou passo intervalar do âmbito $X$ (no caso do temperamento, são doze semitons).

A partir da delimitação dos extremos, pode-se aplicar a fórmula exposta acima para a obtenção de cada novo espaço harmônico proporcional. Menezes utilizou como y o número 32, considerando os 32 semitons presentes entre o si bemol 2 e o fá sustenido 5 da entidade de base em seu âmbito original (ou o número total de graus que 
esta entidade varre de si bemol 2 a fá sustenido 5). Por exemplo, para comprimir esta estrutura no intervalo de terça maior no centro da entidade de base (dó $262 \mathrm{~Hz}$ - mi $330 \mathrm{~Hz}$ ), são calculadas frequências intermediárias entre estes extremos utilizando o novo passo intervalar, que valerá como degrau fixo para estabelecer o novo campo discreto proporcional à entidade de base. Assim, haverá 32 frequências entre o dó $262 \mathrm{~Hz}$ e o mi $330 \mathrm{~Hz}$ mencionado, 32 entre o lá bemol $208 \mathrm{~Hz}$ e o sol sustenido $415 \mathrm{~Hz}$, e assim por diante.

Para cada novo âmbito, é importante notar que o passo intervalar será diferente - serão sempre 32 passos ao total, porém projetados em âmbitos distintos. Para a sétima projeção, por exemplo, para calcular o $X$ do âmbito entre o Si $62 \mathrm{~Hz}$ e o Fá $1397 \mathrm{~Hz}$, temos a razão $X=1397 / 62=22,5323$. Fazendo então $\sqrt[32]{X}$, obteremos a unidade mínima a ser multiplicada por cada frequência (equivalente ao fator 1,0594 do temperamento): $\sqrt[32]{22,5323}=1,1022$. O compositor construiu então uma tabela contendo os 33 valores para cada projeção (ver Tabela 2).

$\mathrm{Na}$ aplicação prática destes valores na composição, as duas últimas projeções (duas últimas colunas da tabela a seguir) foram "sacrificadas" (Menezes, 1998, p.88) - o compositor optou pela manipulação dos dados da tabela para constituir os dois últimos segmentos equivalentes (Music V7 e 8): "todos esses sons que apontaram para um relativo desvio do plano original foram sintetizados sempre a partir de manipulações livres da tabela a seguir exposta, visando à obtenção de sons que interessavam pela mera escuta" (idem, ibidem, nota 33, p.98).

No início da aplicação da $6^{\mathrm{a}}$ projeção na partitura (Music V6, p.10, terceiro sistema) ocorre a mobilidade de parciais utilizados no estrato eletroacústico, já mencionada previamente: como a percepção de perfis na camada eletroacústica é reduzida neste trecho, o que se apreende deste som Music V6 é mais uma dinamização do espectro e uma preparação para o "clímax dramático" (idem, ibidem), atingido neste segmento.

Este clímax é valorizado por uma direcionalidade geral ao registro agudo, possibilitada pela ordem crescente da apresentação 
Tabela 2 - Dados frequenciais obtidos pela técnica das projeções proporcionais

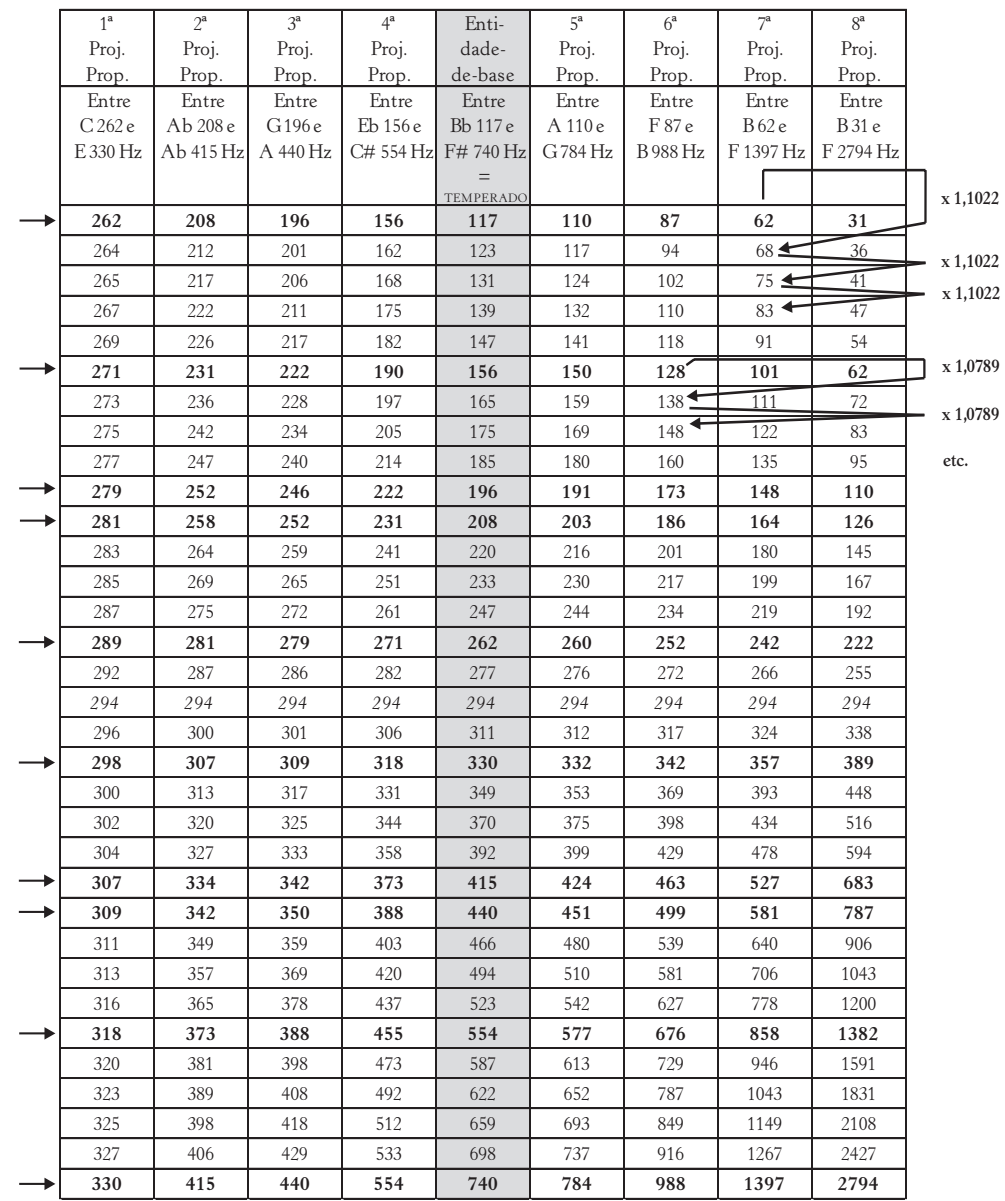

Os valores resultam da fórmula já demonstrada, sendo os valores de cada coluna múltiplos de $\sqrt[y]{X}\left(1,1022\right.$ para a $7^{\mathrm{a}}$ coluna, 1,0789 para a $6^{\mathrm{a}}$ coluna etc. $)$. As frequências utilizadas na peça a partir desta tabela pertencem à mesma linha que as frequências correspondentes na entidade de base (veja as linhas indicadas com uma seta à esquerda da tabela), relativas às dez notas proporcionais daquela entidade (Menezes, 1998). Nota-se que uma oitava projeção foi calculada ainda (última coluna da tabela), referente a um intervalo de oitava além de cada extremo da $7^{\mathrm{a}}$ projeção: entre um si $31 \mathrm{~Hz}$ e um fá $2794 \mathrm{~Hz}$.

Fonte: comentários do autor sobre Menezes (1998). 
das projeções proporcionais na partitura, do âmbito mais estreito $\left(262 \mathrm{~Hz}\right.$ a $330 \mathrm{~Hz}$ na $1^{\mathrm{a}}$ projeção ou segmento relativo ao Music V1) ao mais amplo $\left(31 \mathrm{~Hz}\right.$ a $2794 \mathrm{~Hz}$ na $8^{\mathrm{a}}$ projeção ou segmento relativo ao Music V8, contendo sons já bastante agudos). Este direcionamento acompanha o movimento da flauta solista, que parte de perfis mais "achatados" e os "expande" gradualmente a saltos mais amplos por mobilidade de oitavas, atingindo no clímax um si bemol 6 ao fim do primeiro sistema da página 11 da partitura (12’16”).

\section{As projeções proporcionais na elaboração dos perfis da flauta}

No caso das frequências utilizadas para compor os perfis microtonais da flauta no início da seção, foram recalculadas quatro projeções proporcionais (quatro concreções do perfil principal) e adequadas à notação em quartos de tom. Para obter os novos âmbitos de compressão, Menezes adota um método diferente: o total de passos intervalares $y$ passa a ser 24 semitons, referente às duas oitavas cobertas pelo perfil principal (ante os 32 semitons do âmbito da entidade de base). Tomando o total de 28 notas do perfil, dividido simetricamente com base no número 13 da série de Fibonacci - treze notas antes do intervalo de $13 \mathrm{~m}$ central C-Ab e treze notas depois -, Flo Menezes estabelece grupos de densidades de 1 a 7 notas, de maneira a totalizar o número 28 do perfil $(1+2+3+4+5+6+7=28$, ver figura seguinte). Estes grupos formam, portanto, uma série de densidades: $:^{27} 1,4,3,7,6,2,5$ ( $1^{\circ}$ grupo de densidades: $1^{\mathrm{a}}$ nota do perfil; $2^{\circ}$ grupo: quatro notas seguintes; $3^{\circ}$ grupo: três notas seguintes, e assim por diante). Quatro valores centrais desta série (4, 3, 6 e 2) foram escolhidos para formar quatro novos âmbitos, menores que a extensão de duas oitavas (24 semitons): o cálculo foi realizado pelas frações 4/7, 3/7, 6/7 e 2/7 do total de 24 semitons. As alturas para delimitar cada âmbito de compressão foram escolhidas em um

27 Estes grupos de densidades também serão utilizados na composição de durações, evidenciando a extensão organizativa do material das estruturas harmônicas às temporais. 
procedimento análogo ao adotado no caso dos sons sintéticos, ou seja, intervalos menores que partem de um núcleo mais central do perfil em direção às extremidades do registro (âmbitos formados por notas mais graves e mais agudas):

$2 / 7 * 24=6,86$ (sete semitons ou $5 \mathrm{~J}$ ) - alturas escolhidas no centro do perfil: Ab4 (415Hz) e Eb5 $(622 \mathrm{~Hz})$

$3 / 7 * 24=10,3$ (dez semitons ou $7 \mathrm{~m}$ ) - alturas escolhidas: G4 $(392 \mathrm{~Hz})$ e F5 $(698 \mathrm{~Hz})$

$4 / 7 * 24=13,7$ (treze semitons ou 9m) - alturas escolhidas: F4 $(349 \mathrm{~Hz})$ e $\mathrm{G} 5(784 \mathrm{~Hz})$

6/7 * $24=20,6(21$ semitons ou 13M) - alturas escolhidas: C\#4 $(277 \mathrm{~Hz})$ e A\#5 $(932 \mathrm{~Hz})$

$7 / 7 * 24=24$ (24 semitons ou 15J - duas oitavas de C4 a C6)

Figura 22 - Grupos de densidades delimitados no perfil melódico

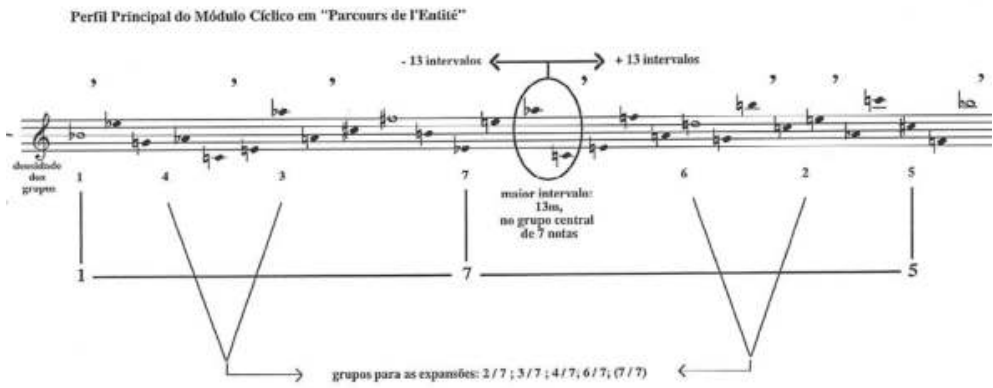

Fonte: comentários do autor sobre Menezes (1998)

As alturas escolhidas para delimitar estes âmbitos estão, portanto, circunscritas à extensão do perfil principal. Para o cálculo do passo intervalar de cada concreção, tomou-se cada um dos novos âmbitos e aplicou-se a mesma fórmula $\sqrt[y]{X}$; agora, $y$ será 24 e o $X$ cada uma das razões entre as frequências dos âmbitos delimitados anteriormente. Uma nova tabela foi realizada no cálculo das projeções (equivalente à tabela para os sons sintéticos), e então se obtiveram, em sequência diacrônica, novas alturas (arredondadas a quartos de 
tom) que formaram "distorções" do perfil principal, "achataram-no” por quatro vezes. Aqui, comparativamente ao que ocorreu na dimensão vertical ("acórdica") com a entidade de base - expansões e concreções -, o redimensionamento deu-se na dimensão horizontal ("melódica") - concreções ou estreitamentos do perfil principal, que mantém, no entanto, seu contorno plenamente reconhecível.

Em resumo, as técnicas para delimitação dos espaços harmônicos foram utilizadas da seguinte maneira:

Figura 23 - Representação esquemática da manipulação do espaço harmônico por meio das técnicas dos módulos cíclicos e projeções proporcionais

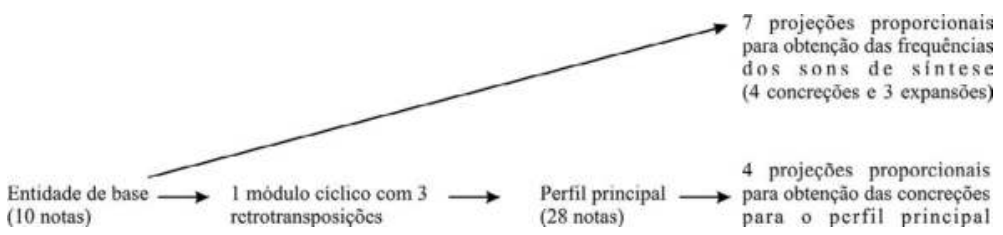

Fonte: elaborada pelo autor

Apesar de o cálculo das projeções proporcionais ter tomado caminhos distintos para o estrato eletroacústico (expansões e concreções da entidade de base) e para o instrumental (apenas concreções do perfil principal da flauta), é fundamental percebermos que a estrutura intervalar de base partiu da mesma entidade de dez notas, que foi comprimida ou expandida no terreno microtonal mas manteve sua proporção de origem.

O perfil principal começa a ser exposto no início da seção em sua forma mais "achatada" no terreno microtonal e vai gradualmente sendo expandido até que, esgotadas as quatro concreções, atinge sua forma original no temperamento. Seguindo as segmentações delimitadas pelas projeções proporcionais dos sons de síntese (Music $V 1$ a 8 , que também caminham do âmbito mais estreito ao mais amplo), esta expansão do material da flauta tende a passar, como já foi dito, de rápidas sucessões de alturas na primeira concreção a valores 
rítmicos com durações mais lentas, desvelando a percepção intervalar do perfil principal.

A solução do compositor para realizar essa transição na partitura foi por uma passagem gradual da notação proporcional à notação convencional: ${ }^{28}$ em 8’38,5" (início da terceira seção) são utilizados grupos de acciaccaturas para compor os perfis microtonais da flauta nos trechos correspondentes ao Music V1 e 2; a partir do Music V3, já há na partitura indicação de andamento (ca. 72 para a colcheia), e além das acciaccaturas são apresentadas figurações rítmicas rápidas, como quiálteras de nove semifusas.

Em Music V4 há novo andamento (ca. 66 para a colcheia), notam-se figurações com valores rítmicos progressivamente maiores, e em Music V5 a peça se estabiliza em ca. 60 para a colcheia, com a apresentação original, dentro do temperamento, do perfil principal. Paralelamente, em um nível estrutural mais amplo, cresce o número de vezes em que se repete o perfil principal: uma apresentação em Music V1 da $1^{\mathrm{a}}$ concreção, duas da $2^{\mathrm{a}}$ concreção em Music V2, três da $3^{\mathrm{a}}$ concreção em Music V3, cinco da $4^{\mathrm{a}}$ concreção em Music V4 e oito a partir de Music V5 no temperamento - mais uma vez, uma organização segundo a série de Fibonacci (tabela seguinte).

28 Algo que será sistematicamente desenvolvido mais tarde, segundo Menezes, em La Novità del Suono (2006) para um grupo maior de instrumentos. 


\begin{tabular}{|c|c|c|c|c|c|c|}
\hline \multirow{10}{*}{ 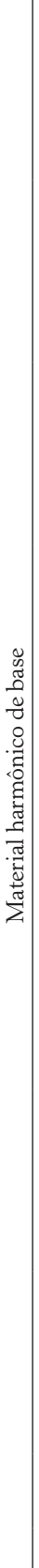 } & \multirow{10}{*}{ 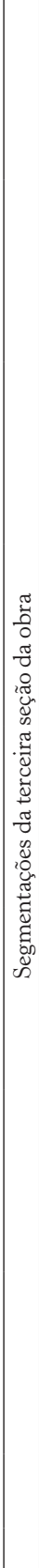 } & 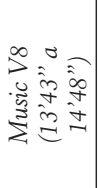 & 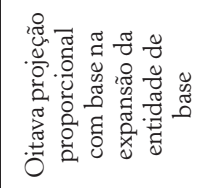 & :ृีّ & 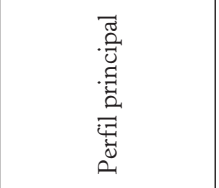 & 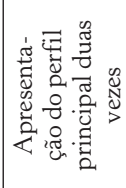 \\
\hline & & 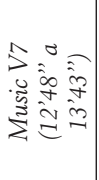 & 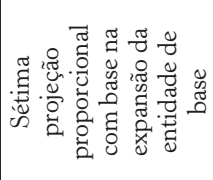 & 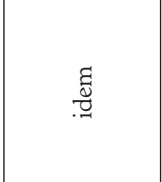 & 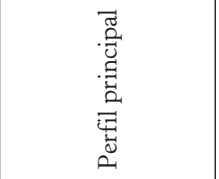 & 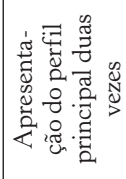 \\
\hline & & 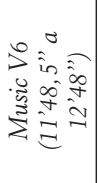 & 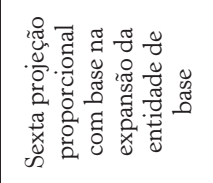 & : & 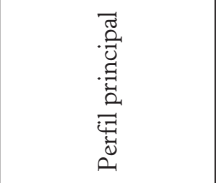 & 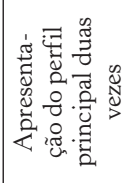 \\
\hline & & 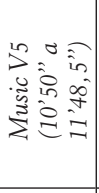 & 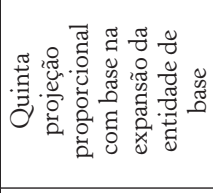 & : & 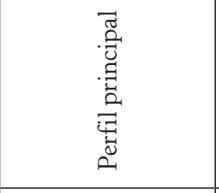 & 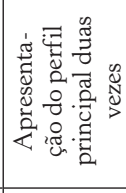 \\
\hline & & 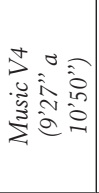 & 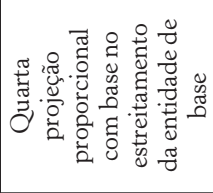 & 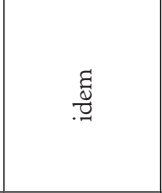 & 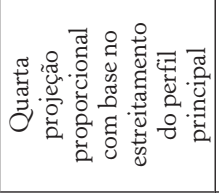 & 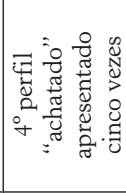 \\
\hline & & 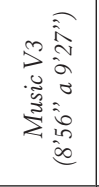 & 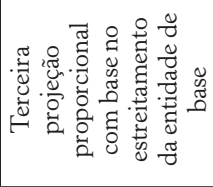 & : & 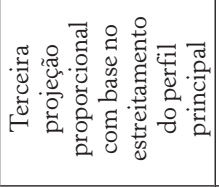 & 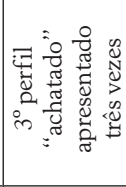 \\
\hline & & 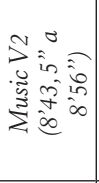 & 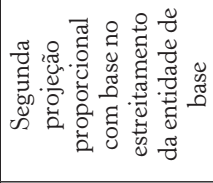 & שֶ, & 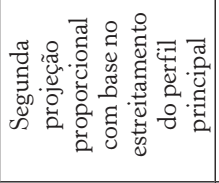 & 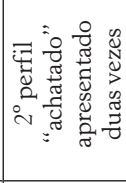 \\
\hline & & 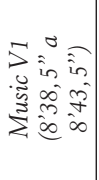 & 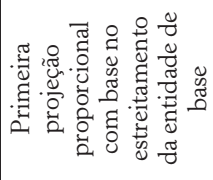 & 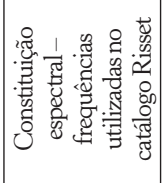 & 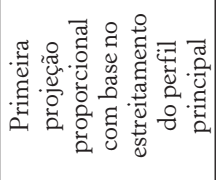 & 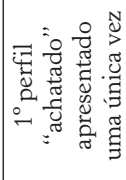 \\
\hline & & & 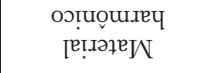 & 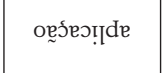 & 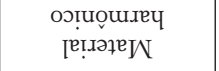 & oeśreว!̣de \\
\hline & & & १U & uos & ath is & \\
\hline
\end{tabular}


Para delimitar as durações de cada uma das oito apresentações do perfil principal no temperamento (a partir de 10'50"), outro procedimento de Menezes tipicamente serial é utilizado: a dinamização da densidade harmônica. Aqui, o compositor opta por tomar a "série" de densidades criada inicialmente $(1,4,3,7,6,2,5)$, atribuindo a cada valor seu correspondente em segundos (portanto, 1", 4", 3", 7”, 6”, 2", 5”), permutando-a em seguida para cada vez que se expõe o perfil.

Tabela 4 - Técnica da dinamização da densidade harmônica

\begin{tabular}{|c|c|c|c|c|c|c|c|}
\hline $1 x$ & 1 nota (1) & $4\left(4^{\prime \prime}\right)$ & $3\left(3^{n}\right)$ & $7\left(7^{\prime \prime}\right)$ & $-6\left(6^{n}\right)$ & $2\left(2^{\prime \prime}\right)$ & $-5\left(5^{n}\right)$ \\
\hline $2 x$ & $3\left(7^{\prime \prime}\right)^{4}$ & $7\left(6^{\prime \prime}\right)$ & $6\left(2^{n}\right)$ & $2\left(5^{\prime \prime}\right)$ & $5\left(1^{n}\right)^{4}$ & $1(4, y)$ & $-4\left(3^{n}\right)$ \\
\hline $3 x$ & $6\left(5^{n}\right)^{4}$ & $2\left(1^{\prime \prime}\right)$ & $-5^{\prime}\left(4^{n}\right)^{4}$ & & & & $-7\left(2^{\prime \prime}\right)$ \\
\hline $4 \mathrm{x}$ & $5\left(3^{n}\right)^{-}$ & $1\left(7^{\prime \prime}\right)^{\prime}$ & $4\left(6^{n}\right)^{4}$ & $3\left(2^{\prime \prime}\right)$ & $7 \cdot\left(5^{\prime}\right)^{4}$ & $6\left(1^{\prime \prime}\right)$ & $-2\left(4^{\prime \prime}\right)$ \\
\hline $5 x$ & $4\left(2^{\prime \prime}\right)^{4}$ & $3\left(5^{\prime \prime}\right)$ & $-7\left(1^{\prime \prime}\right)^{4}$ & $\left.6(4)^{2}\right)$ & $-2\left(3^{n}\right)^{4}$ & $5\left(7^{\prime \prime}\right)$ & $-1\left(6^{n}\right)$ \\
\hline $6 x$ & $7\left(4^{n}\right)^{4}$ & $6\left(3^{\prime \prime}\right)$ & $2\left(7^{n}\right)$ & $5\left(6^{\prime \prime}\right)$ & $-1\left(2^{\prime \prime}\right)$ & $4\left(5^{n}\right)$ & $3\left(1^{\prime \prime}\right)$ \\
\hline $7 x$ & $2\left(6^{n}\right)^{4}$ & $5\left(2^{\prime \prime}\right)$ & $1\left(5^{n}\right)$ & $4\left(1^{\prime \prime}\right)$ & $3\left(4^{\prime \prime}\right)$ & $7\left(3^{\prime \prime}\right)$ & $6\left(7^{\prime \prime}\right)$ \\
\hline $\begin{array}{c}8 \mathrm{x} \\
\text { (duraçöes } \\
\text { multiplica } \\
\text { das por 2) }\end{array}$ & $1\left(2^{\prime \prime}\right)^{-}$ & $4\left(8^{\prime \prime}\right)$ & $3\left(6^{\prime \prime}\right)$ & $7\left(14^{n}\right)$ & $6\left(12^{\prime \prime}\right)$ & $2\left(4^{\pi}\right)$ & $5\left(10^{\prime \prime}\right)$ \\
\hline
\end{tabular}

A técnica é aplicada à composição de durações do perfil principal, a partir do Music V5 em 10’50" (Menezes, 1998, p.94). A primeira coluna indica cada uma das oito apresentações do perfil. Nas demais colunas, os números da esquerda representam a densidade de notas por figura e os da direita (entre parênteses) sua duração.

Fonte: Menezes (1998)

Há, portanto, na composição das durações da terceira seção como um todo, três grandes níveis: o primeiro, referente ao aumento do número de repetições do perfil a cada segmento do Music V; o segundo, à transição da notação proporcional à notação métrica; o terceiro, às figurações rítmicas de cada exposição do perfil que, para as oito 
apresentações no temperamento (a partir de Music V5) seguem os valores dos grupos de densidades da tabela anterior.

A transição gradual dos contornos microtonais aos intervalos temperados do perfil principal estabelece uma dualidade de perspectivas na escuta dentro da dimensão gestual: intercambiam-se ora a percepção de contorno, ora a escuta de intervalos recorrentes e hierarquicamente importantes do perfil principal. Nesse sentido, alguns contornos fragmentados na evolução do material da flauta adquirem uma unidade, singularizam-se à percepção, compondo o que poderíamos denominar "protoperfis", pequenas unidades melódicas formativas referentes a segmentos do perfil principal. Tais elementos, com forte apelo gestual, apresentam-se como "recortes" de uma síntese realizada pela escuta a partir da estrutura mais ampla apresentada (o perfil em si). Por constituírem uma "síntese", uma apreensão geral localizada, tais protoperfis mantêm, da mesma forma como os perfis em um nível mais amplo, o mesmo contorno, porém com conteúdo intervalar "distorcido" (via projeções proporcionais ou mesmo com pequenos desvios dentro do próprio temperamento). Estes “pontos de apoio” à escuta em meio a rápidas sucessões de alturas formam os momentos em que se tem a certeza de estar defronte da estrutura comum e conhecida, ou seja, de figuras conhecidas. Denotam ainda a forte correlação no uso da técnica das projeções proporcionais em conjunto com a composição de perfis. A progressão de contornos microtonais ao perfil principal "temperado" torna-se, deste modo, extremamente direcional e expressiva (ver exemplos de protoperfis nas figuras a seguir).

O que foi denominado "protoperfil" delineia o reconhecimento auditivo de segmentos parciais recorrentes: os trechos circulados nas figuras seguintes mostram exatamente o início do perfil, início dessa unidade estrutural, com pequenos desvios em relação a como são apresentados no temperamento. Uma frase de Boulez também parece esclarecer outro ponto fundamental da composição de perfis em conjunto com as projeções proporcionais em Parcours... Ainda mais que o temperamento é extrapolado, é possível dizer que o compositor buscou unidade por meio dessas figuras mostradas a seguir, do 
Figura 24 - Repetição progressiva, na terceira seção formal da obra, de unidades melódicas com maior propensão de "síntese" pela escuta (protoperfis)
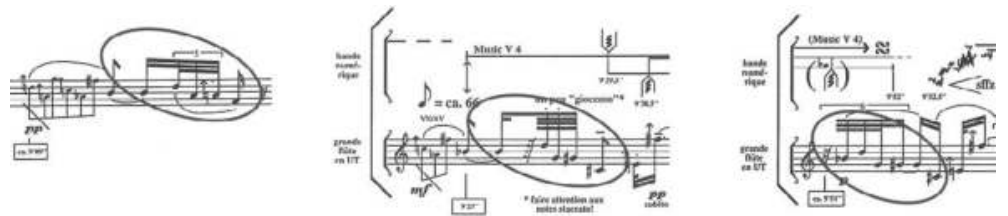

O contorno entre as figuras é muito similar, com pequenos desvios na estrutura interna em relação a um conteúdo "original". Compare as figuras circuladas acima com sua disposição "temperada" no perfil principal, mostrado a seguir.

Fonte: comentários do autor sobre Menezes (1998)

Figura 25 - Primeira apresentação do perfil principal no temperamento, aos 10'50"

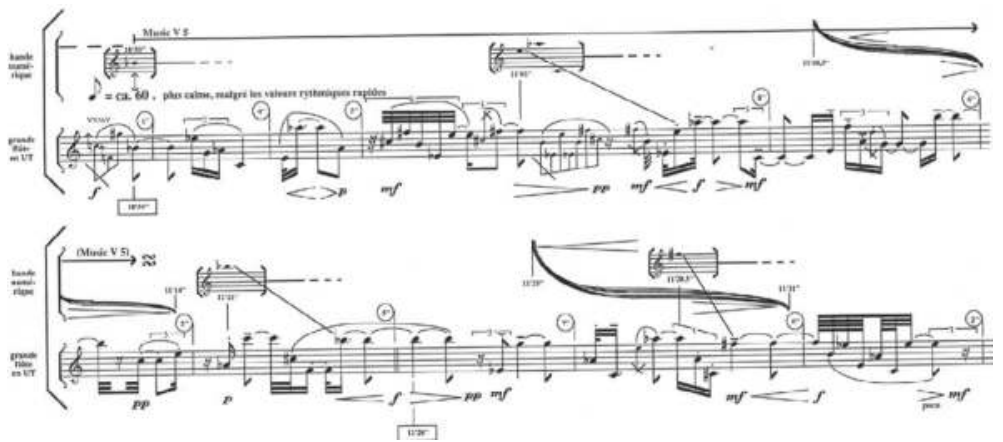

Fonte: Menezes (1998)

reconhecimento auditivo de "unidades estruturais", mas também por uma localização bem definida de registro: "Num campo restrito [em termos de tessitura], o emprego dos microintervalos desempenha um papel de ampliação, e a orelha adquire - momentaneamente - uma sensibilidade que ela não poderá conservar num âmbito mais amplo, no qual então ela restabelecerá uma escala de apreciação conforme a dimensão dos intervalos utilizados" (Boulez, 1986, p.90). A delimitação do registro - o registro médio é utilizado, já que nossa 
capacidade auditiva de diferenciação é maior nesse âmbito - e a criteriosa escolha de um perfil principal permitiram que o compositor garantisse o movimento direcional ao perfil de base.

\section{Altra voce, de Luciano Berio}

\section{Luciano Berio na fase de criação do Centro Tempo Reale}

A trajetória de Luciano Berio na música eletroacústica mista revela uma busca contínua pela superação do estatuto das "duas dimensões" (instrumental e eletroacústica), demonstrando maior interesse nos recursos eletrônicos como uma maneira de expandir o universo instrumental; mas uma expansão sutil o suficiente, em especial no que se refere a transfigurações espectro-morfológicas do material instrumental, para não descaracterizar sua identidade e sua história. Talvez o impacto mais profundo do uso de recursos informáticos nesta última fase da obra de Berio tenha sido no fator espaço, seja pela dinamização de trajetórias sonoras, controle na distribuição e diferenciação de camadas que compõem polifonias mais complexas, seja no tocante ao equilíbrio geral e adaptação ao espaço da performance, especialmente quando o compositor prevê distribuições inusitadas de grupos instrumentais.

Pensa-se aqui, fundamentalmente, nas obras do compositor italiano com live electronics a partir do final dos anos 1980: Outis (1996, azione musicale para coro e orquestra), Ofanim (1988 e revisada em 1997, azione musicale para dois coros infantis e orquestra) e Altra voce (1999, para mezzosoprano e flauta contralto), obra que analisaremos neste capítulo. Em Outis, os realces quase imperceptíveis do processamento eletrônico são muito valiosos para ilustrar o pensamento de Berio com relação ao uso do live electronics, buscando uma situação de expansão dos sons instrumentais tão sutil no espaço a ponto de justificar a "camuflagem" de alguns grupos de alto-falantes, suprimindo-os da visão do público na estreia da obra no 
Teatro alla Scala de Milão: "Neste trabalho - no qual não há, de fato, live electronics, mas há um grande respeito pela substância acústica musical e pelo espaço em si - a tecnologia tende a prolongar certos aspectos, a desenvolvê-los internamente de um modo que poderiam ser quase chamados de dissimulados ou mascarados" (Berio apud Giomi; Meacci; Schwoon, 2003).

É ainda notável a participação do Centro Tempo Reale na estreia de Cronaca del Luogo (1999, última azione musicale de Berio), em um caso representativo do uso de recursos eletrônicos para adaptar a realização musical prevista a um espaço altamente não convencional - a arquitetura do Felsenreitschule (Salzburgo), como veremos. Além disso, é notável a disposição totalmente inusitada da orquestra, em uma espécie de "parede" musical na qual coro e instrumentistas foram distribuídos não apenas lado a lado, mas também acima uns dos outros. ${ }^{29}$

Berio desenvolveu uma extensa e importante produção musical em estúdio, desde a fundação do Studio di Fonologia Musicale em Milão ao lado de Bruno Maderna (1955), posteriormente como responsável pelo setor de música eletroacústica do Ircam em Paris a convite de Pierre Boulez (1974-80) e, finalmente, com a fundação do Centro Tempo Reale em Florença (1987). ${ }^{30}$ Durante esta longa trajetória, fica patente sua preocupação em utilizar os recursos tecnológicos a serviço das ideias musicais "como extensão do trabalho humano", sendo bastante crítico a uma produção eletroacústica

29 Segundo o texto já mencionado de Giomi, Meacci e Schwoon, é notório o recurso da amplificação com intenções semelhantes em Berio desde obras como Allelujah II (1956-58), Sinfonia (1968-69), Coro (1974) e Formazioni (1985-87). Vale lembrar que Francesco Giomi, um dos autores do texto citado, é o atual diretor do Centro Tempo Reale, tendo colaborado ativamente com Luciano Berio em seu trabalho com live electronics.

30 Investiguei a trajetória de Berio envolvendo música eletroacústica desde as origens do Studio di Fonologia Musicale de Milão em conferência realizada no "Simpósio Berio, Dez Anos Depois", em outubro de 2013, juntamente com Fábio Scucuglia. O pensamento do compositor italiano acerca das funções do aparato eletroacústico é bastante consistente desde aqueles anos iniciais. A este respeito, ver especialmente Berio (1985 [1981] e 2013). 
voltada à simples geração de "novos sons" ${ }^{31} \mathrm{O}$ compositor enfatiza em diversos textos sua crença na necessidade de dar continuidade ao legado da música, de levá-la adiante a partir de conhecimentos e experiências sedimentados, valorizando inclusive a história dos instrumentos musicais. Não por acaso, as obras com live-electronics realizadas neste período do Centro Tempo Reale (CTR) procuram destacar nuances da escritura instrumental, sutilezas tanto voltadas ao campo timbre-harmonia quanto ao campo do espaço - seja no tocante à distribuição de planos de profundidades, equilíbrio geral no espaço da performance, seja pelas trajetórias espaciais dos sons.

A partir da década de 1970 Berio passa a se interessar mais especificamente pelo processamento em tempo real (live-electronics), especialmente pela intenção de homogeneizar fontes instrumentais e eletroacústicas - uma fusão essencialmente caracterizada pelo universo instrumental. Nesse período, portanto, ele parece ter começado a vislumbrar caminhos na música eletroacústica mista por meio do live electronics para desenvolver um aspecto em que já insistia desde a década de 1950: a tão almejada continuidade entre as esferas instrumental e eletroacústica. Com efeito, o compositor revela estar certo que "a antinomia das 'duas dimensões' - o contraste entre música gravada (ou seja, eletrônica) e música realmente executada (instrumentos, voz cantada ou falada) - também poderá ser muito em breve superada" (Berio, 1959 in Menezes, 2009 [1996]). O contraste extremo entre "duas dimensões" é evocado no contexto pela obra de Maderna - Musica su Due Dimensioni (1952). É possível vislumbrar então, pelo texto publicado em 1959, que Berio já estivesse muito interessado em um esfacelamento das fronteiras, uma continuidade e interação mais fluidas entre o instrumental e o eletroacústico desde aquela época. Muito embora existam obras suas que revelam grande

31 Berio chama de "totalmente inócuo" e árido musicalmente, embora surpreendente pelo campo aberto de novas possibilidades, seu primeiro contato com a música eletroacústica em um concerto no Museum of Modern Art (MoMA) em Nova Iorque, onde ouviu quatro obras para tape de Wladimir Ussachevsky e Otto Luening (Berio apud de Benedictis, 2012, p.8; Berio, 1985 [1981], p.117). 
contraste entre os materiais eletroacústico e instrumental, como Différences (1959) ou Laborintus II (1965), é possível dizer que foi pelas obras com live-electronics a partir do final da década de 1980 que o compositor pôde aproximar-se de fato desta ideia.

Uma consequência imediata deste pensamento (e da prática composicional de Berio) é que, uma vez que os meios instrumentais poderiam incorporar expansões eletroacústicas de maneira contínua, a experiência em estúdio passa a ser considerada absolutamente fundamental, transformando-se em parte assimilada da formação do músico:

Música eletrônica, em um certo sentido, não mais existe, já que está por todo lado e constitui parte do pensamento musical de todos os dias. Podemos descrever as técnicas específicas, mas não há mais como sustentar a música eletrônica como a antítese de outros modos e concepções da criação musical [...]. Desta forma, um músico de hoje que não explore o mundo da música eletrônica é necessariamente um músico incompleto. (Berio apud Giomi; Cremaschi, 2004, p. 27$)^{32}$

Esta citação, originalmente extraída do prefácio do compositor italiano no livro organizado por Henri Pousseur La musica elettronica (1976), vai ao encontro das obras com eletrônica em tempo real realizadas no Centro Tempo Reale que, de fato, exploram esta sutileza da qual falava Berio: uma homogeneidade entre fontes instrumentais e vocais, de um lado, e eletroacústicas, de outro, sem contrastes ou transformações radicais entre as duas esferas.

32 No original: "Electronic music, in a certain sense, no longer exists because it is everywhere and is a part of everyday musical thought. We can describe the specific techniques but we can no longer hold electronic music up as the antithesis of other modes and conceptions of musical creation [...] As a result, a musician of today who does not explore the world of electronic music is necessarily incomplete". 


\section{Altra voce, para flauta contralto, mezzosoprano e live- -electronics (Luciano Berio, 1999) ${ }^{33}$}

\author{
non è giorno nè notte \\ un suono di tromba, quasi \\ un suono di flauto, quasi \\ di vento e di mare \\ di voci di vento \\ vieni \\ apri gli occhi \\ ascolta \\ il vecchio piange \\ padre e figlio \\ sono caduti sui monti. \\ sento un'altra voce \\ vieni $^{34}$
}

\author{
não é dia nem noite \\ um som de trompete, quase \\ um som de flauta, quase \\ de vento e de mar \\ de voz e de vento \\ venha \\ abra os olhos \\ escute \\ o velho chora \\ pai e filho \\ jazem sobre a colina. \\ sinto uma outra voz \\ venha. (tradução livre)
}

33 Diferentemente do caso de Parcours de l'Entité, cuja análise harmônica minuciosa ocupou um grande espaço deste trabalho, Altra voce será analisada sob um olhar mais restrito aos diversos aspectos da interação entre os meios instrumentais e eletroacústicos. A partitura utilizada (Universal Edition UE35958) foi publicada quase dez anos depois da estreia e contém o manual técnico elaborado pelo Centro Tempo Reale. Giomi e Schwoon (2005) revelam que, especialmente após a performance no Carnegie Hall (NY), em 2001, Berio efetuou as principais alterações na parte eletroacústica (inclusive nas adições de intervalos de quarta pelo harmonizer na segunda seção da peça). No texto de Giomi e Schwoon (ibidem) sobre Altra voce, figuras retiradas da partitura revelam que a versão utilizada por eles é diferente (ao menos nas indicações dos eventos eletroacústicos), menos detalhada que a utilizada aqui.

34 Texto de Talia Pecker Berio, viúva do compositor. Esta versão consta na partitura como tendo passado por pequenas alterações por Berio. Ao receber as notas de programa da obra via Francesco Giomi (diretor do Centro Tempo Reale), deparei com uma versão levemente diferente do texto, sugerindo que poderia tratar-se da versão original: non è giorno nè notte / un suono di tromba, quasi / un suono di flauto, quasi / di voce e di vento. / Vieni. / Apri gli occhi / Ascolta / Il vecchio piange, / Padre e figlio / sono caduti sui monti. / Sento un'altra voce. / Vieni. 
Esta obra, que caracteriza a última fase do compositor italiano no tocante ao uso de recursos eletroacústicos em tempo real, é resultado de um desenvolvimento da cena Il campo de Cronaca del Luogo (também de 1999, para atores, coro, solistas e orquestra). ${ }^{35}$ Última azione musicale de Berio, a obra foi estreada em Salzburg no inusitado Felsenreitschule, uma espécie de teatro a céu aberto, cuja estrutura arquitetônica permitiu uma disposição vertical do coro e orquestra em nichos existentes na parede de fundo do palco, numa espécie de "muralha harmônica". A participação do Centro Tempo Reale na realização da performance reforça os desafios de ordem prática com relação a equilíbrio orquestral, projeção sonora e problemas de execução somente contornáveis com recursos eletrônicos. ${ }^{36}$ Nota-se, ainda, a preponderância que o espaço da performance adquire para o compositor italiano, justificando mais e mais o uso da "informática musical", adaptando e permitindo a realização de obras em espaços diversos, com distribuições igualmente diversas dos músicos em cada novo espaço.

Um artigo escrito por Berio à época da estreia mostra claramente esta preocupação que, no caso da disposição verticalizada dos músicos em Cronaca del Luogo, tem um antecedente na obra do compositor em Coro (1975-76):

Este trabalho [...] é fortemente condicionado ao lugar da sua execução, a Felsenreitschule de Salzburgo. É, em suma, também uma "crônica do lugar". A Felsenreitschule é um espaço que sempre me fascinou. [...] Em Cronaca del Luogo, coro e instrumentos são distribuídos naquele muro escavado na rocha, com cerca de 25 metros de altura por 30 metros de largura, diante de uma "praça" sobre a qual podem ocorrer ações e que pode ser coabitada por presenças (não só vocais) bastante diversas entre si. Nesta praça a figura de R é uma presença monumental e é inevitável que ela provoque,

35 O texto integral é igualmente de Talia Pecker Berio.

36 A estreia foi feita com colaboração do CTR e do Laboratorio di Informatica Musicale dell'Università di Genova. 
frequentemente, a história vocal e intelectual da sua intérprete. [...] Do ponto de vista acústico, a estratégia vocal e instrumental é por vezes análoga àquela que eu já havia experimentado em Coro, mesmo que aquela experiência musicalmente esteja muito distante, e com a diferença substancial de que em Cronaca del Luogo vozes e instrumentos são distribuídos verticalmente no muro. [...] Esta verticalidade desenvolve e intensifica suas razões acústicas e musicais também graças ao emprego de diversas tecnologias informáticas. (Berio, 2013 [1999], p.305-6) ${ }^{37}$

Além da referência ao gesto vocal definido com a presença da intérprete - que na estreia foi Hildegard Behrens -, fica evidente a figura de " $\mathrm{R}$ " e a flauta contralto que comporão o universo de Altra voce, ao lado, é claro, da readaptação e expansão definidas pelo compositor por meio do live-electronics.

A metáfora visual do "muro", representada pela disposição dos músicos ao longo da parede de fundo na performance, surge no discurso de Talia Pecker Berio (apud Giomi; Schwoon, 2005, p.71) para trazer certa memória que o objeto contém; o muro encerra em sua opacidade e dureza referências brutas, cegas e ríspidas, mas também uma solidez que possibilita um paralelo com a trajetória da cultura hebraica:

37 No original: "Questo lavoro [...] è fortemente condizionato dal luogo della sua esecuzione, la Felsenreitschule di Salisburgo. È, insomma, anche una "chronique du lieu”. La Felsenreitschule è uno spazio che mi ha sempre affascinato. [...] In Cronaca del Luogo coro e strumenti vengono distribuiti in quel muro scavato nella roccia, alto circa 25 metri e largo 30, sovrastante una "piazza" sulla quale possono prendere forma le azioni e che può essere abitata da presenze (non solo vocali) molto diverse fra loro. In quella piazza la figura di $R$ è una presenza monumentale ed è inevitabile che essa provochi, a tratti, la storia vocale e intellettuale della sua interprete. [...] Dal punto di vista acustico la strategia vocale e strumentale è talvolta analoga a quella che avevo già sperimentato in Coro, anche se musicalmente ne è lontanissima e con la differenza sostanziale che in Cronaca del Luogo voci e strumenti sono distribuiti verticalmente nel muro. [...] Questa verticalità sviluppa e intensifica le sue ragioni acustiche e musicali anche grazie all'impiego di diversi tecnologie informatiche". 
Cronaca del luogo não é tanto uma crônica de eventos e lugares da história hebraica, mas sobretudo uma visitação de lugares e situações mentais que sugerem cenas hebraicas, bíblicas ou não, e tomam forma diante de nossos olhos e nossos ouvidos, em um espaço definido diante da imponente presença do muro, da memória que ele contém, da sua voz e da música que em tudo isto ressoa. (tradução livre)

É curioso que, na cena Il Campo, a flauta contralto deva mover-se pelo palco - com o intuito de seguir Orvid, "alter ego poético do protagonista ' $\mathrm{R}$ ', interpretado por um mezzosoprano", que no texto de Pecker Berio representa uma mescla entre Orfeo e David (Giomi; Schwoon, 2005, p.69) -, enquanto em Altra voce o flautista e a cantora devam ficar sentados e atrás de uma mesa durante toda a peça. Além do canto onírico de Orfeu, há referências à batalha de libertação do povo de Israel contra o domínio Filisteu - Saul e o filho Jônatas, que podem estar presentes no texto representados pelo trecho em que pai e filho perecem (idem, ibidem). ${ }^{38}$ Tal transmutação do lugar de realização de Il Campo determina a importância que o tratamento do espaço com recursos eletroacústicos adquire não só na peça quanto no pensamento musical em geral de Berio, que leva a espaços radicalmente distintos a mesma cena musical:

Em um episódio (Il Campo) da minha ação musical (azione musicale) "Cronaca del luogo" há um dueto de amor virtual. Duas vozes e alguns instrumentos se "amam" e perseguem uns aos outros em uma relação constantemente renovada. Como todos sabemos, em uma verdadeira polifonia as diversas vozes contribuem ao conjunto, conservando, entretanto, sua identidade e ao mesmo tempo sua autonomia.

38 Giomi e Schwoon também aprofundam as múltiplas referências textuais que habitam o libreto de Cronaca del Luogo, como os trechos de Paul Celan e de Dante. Embora importante para pensar o texto integralmente, considerei suficientes as referências já utilizadas no recorte textual de Altra voce. É ainda digno de nota, curiosamente, que o texto de Ofanìm (1988) também contenha referências a escritos religiosos, partindo do Velho Testamento (Livro de Ezequiel). 
Pois bem, em Altra voce isolei uma voz do grupo (mezzosoprano) e um instrumento (flauta contralto), e desenvolvi a autonomia e as premissas harmônicas também - mas não só - por meio do emprego das tecnologias informáticas. ${ }^{39}$

A especificação "não só", adicionada pelo compositor na citação acima, realça um aspecto marcante da escritura de Altra voce: o que o próprio Berio definiu como o esfacelamento da fronteira entre melodia e polifonia. De maneira similar à instabilidade do "muro harmônico" de Cronaca del Luogo, em Altra voce ocorrem alternâncias frequentes entre voz e flauta para uma mesma altura, criando não só modulações de timbre como também alterações de profundidades e localização espacial no relevo sonoro com o auxílio dos recursos informáticos. As adições e transformações eletroacústicas somente ampliam, desta forma, uma questão central da composição que já está presente na escritura instrumental:

[A composição] desenvolve uma interessante polifonia de sons que se movem rompendo o espaço da apresentação. Enquanto se escuta a voz ou a flauta, podem-se ao mesmo tempo ouvir as transformações sonoras que ocorrem. A separação entre melodia e polifonia é suprimida, uma torna-se a outra e ambas respiram juntas. Este é um elemento muito significativo da peça. (Berio apud Giomi; Schwoon, 2005, p.75) 40 $^{40}$

39 No original: "In un episodio (Il Campo) della mia azione musicale Cronaca del Luogo, c'è un duetto d'amore virtuale. Due voci e alcuni strumenti si "amano" $e$ si seguono l'un l'altro in un rapporto costantemente rinnovato. Come tutti sanno, in una vera polifonia le diverse voci contribuiscono all'insieme conservando però la loro identitä se non addirittura la loro autonomia. Ebbene, in Altra Voce ho isolato dall'insieme una voce (mezzo-soprano) e uno strumento (flauto alto) e ne ho sviluppato l'autonomia e le premesse armoniche, anche - ma non solo-attraverso l'impiego di tecnologie informatiche" (Berio em nota de programa de Altra voce, gentilmente fornecida por F. Giomi, diretor do Centro Tempo Reale).

40 No original: "[La composizione] sviluppa un'interessante polifonia di suoni che si muovono riempiendo lo spazio esecutivo. Mentre si ascolta la voce o il flauto, si può contemporaneamente udire le trasformazioni sonore che avvengono. La separazione tra melodia e polifonia è cancellata, una diventa l'altra ed entrambe respirano insieme. Questo è un elemento molto significativo del pezzo". 
Esta noção de polifonia é diretamente ligada à experiência da música eletroacústica: além da distribuição de profundidades e localizações espaciais distintas, nota-se uma aproximação interessante do que diz Berio com a busca pelo esfacelamento entre harmonia e timbre, como apontamos tanto em Murail quanto em Harvey. Afinal, quando uma melodia se dilui em uma polifonia que abarca outras figuras e objetos sonoros advindos do discurso musical, a própria noção de polifonia é ampliada. Camadas ou objetos sonoros se entrecruzam no espaço e, eventualmente, podem ser constituídos, ainda que não somente, por melodias; os contornos e as modulações de timbre que surgem na confluência das diferentes "vozes" constroem uma polifonia que, especialmente com a contribuição dos meios eletroacústicos, pode realçar elementos diferentes. Isto ocorre, por exemplo, no trecho da Introdução da peça em que uma figura representada por um frullato na flauta é também encontrada na extensão do $r$ da palavra giorno (dia) pela voz; da mesma maneira, iterações pela repetição staccato na flauta ocorrem próximas ao som da consoante $t$ em notte (noite) - nesse momento, cada qual realiza trajetórias espaciais específicas, valorizando a dinamização e contraposição desses elementos no espaço.

A partitura nos remete a uma escritura polifônica muito direta e clara, em um tecido permissível o suficiente para abarcar os materiais produzidos pela esfera eletroacústica: veremos que a adição instrumental será o principal material agregado pelos processamentos eletroacústicos. E, nos momentos em que há acúmulo de camadas ou processos eletroacústicos concomitantes, resultando em um grande adensamento (como no momento que antecede o Epílogo), a espacialização entra como fator crucial para segregar tais camadas. Em outras palavras, a espacialização permite a diferenciação de eventos sonoros concomitantes que, caso contrário, seriam majoritariamente percebidos como uma textura única. Esta adição ocorre, em Altra voce, essencialmente de duas maneiras: como um "pedal" que acompanha o desenvolvimento dos materiais da flauta e da voz, com variações sutis em densidades e estrutura harmônica - reprodução em loop de notas alongadas tocadas e gravadas pela voz e flauta -, e 
como reprodução deslocada de materiais mais dinâmicos, articulados em perfis ou elementos iterados, já tocados pelos instrumentos. Observemos nas duas figuras seguintes um trecho da partitura que contém estes dois elementos essenciais:

Figura 26 - Primeiro evento eletroacústico de Altra voce

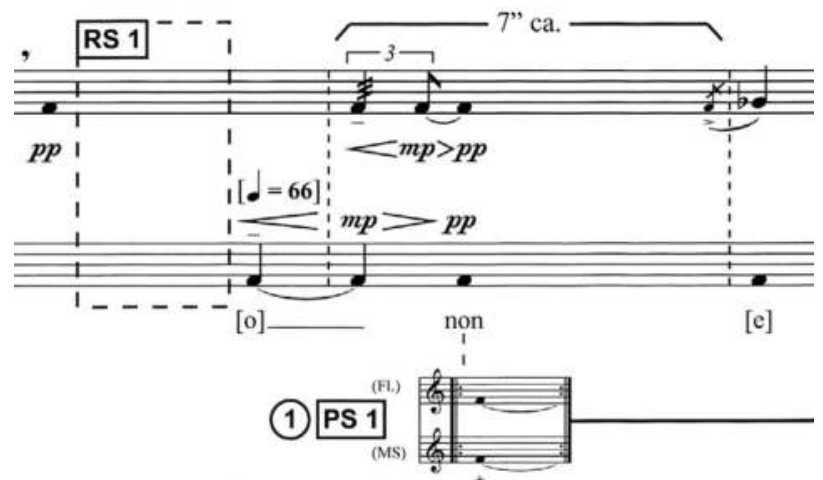

Reprodução em loop de trecho gravado ao vivo do fá em uníssono realizado pela voz e flauta (PS indica play sample; RS, record sample, reprodução do trecho gravado anteriormente). Este evento (pedal) permanece até o final da obra. Observação importante a todos os excertos da partitura daqui em diante: a flauta contralto soa como está escrita na partitura.

Fonte: Luciano Berio "Altra Voce” (C) Copyright 1999 by Universal Edition A.G., Wien/UE 35958

Figura 27 - Décimo evento eletroacústico de Altra voce

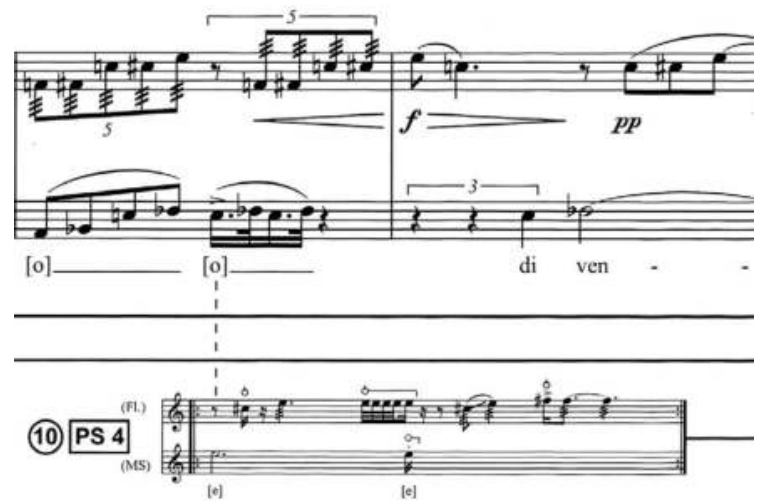

Reprodução de outro trecho gravado durante a performance sobreposto à realização ao vivo, em clara adição instrumental, ampliando a escritura polifônica da peça.

Fonte: Luciano Berio “Altra Voce” (c) Copyright 1999 by Universal Edition A.G., Wien/UE 35958 
Instruções para a realização da obra ${ }^{41}$

O manual técnico que acompanha a partitura estabelece de forma bastante criteriosa a montagem da performance, com figuras e diagramas relativos às disposições dos alto-falantes, característica geral da iluminação, além do principal elemento cênico da peça, uma mesa centrada no palco, atrás da qual devem sentar-se o flautista e a cantora.

Figura 28 - Esquema das dimensões da mesa que deve ocupar o centro do palco

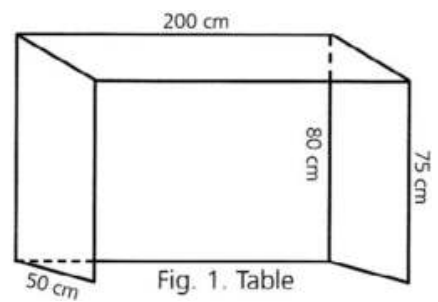

Fonte: Luciano Berio “Altra Voce” (c) Copyright 1999 by Universal Edition A.G., Wien/UE 35958

Em relação ao processamento em tempo real, o que torna o estudo desta obra relevante no tocante às anamorfoses é a "ampliação" do corpo instrumental de maneira sutil, como já mencionado. Tecnicamente, são realizados três processamentos: harmonizer, sample playback e espacialização. Vejamos cada um deles em mais detalhes:

- Harmonizer: processamento que resulta em transposição simultânea de altura do sinal de entrada, provoca alterações de frequência em um sinal para cima ou para baixo sem alterar sua duração. A partir de determinados pontos na partitura, são produzidas sequências de transposições de altura para a flauta ou para a voz, conforme o caso, com durações específicas, conforme indicado na figura abaixo:

41 São especificados dois microfones direcionais acoplados às cabeças dos intérpretes (head-worn). 
Figura 29 - Exemplo de como o harmonizeré aplicadoà mezzosoprano

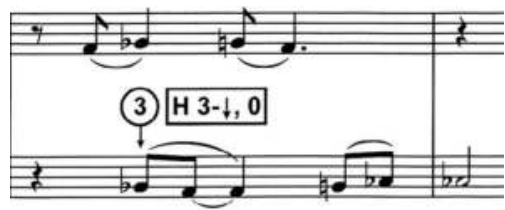

né_ né__ not

Fonte: Luciano Berio “Altra Voce” (c) Copyright 1999 by Universal Edition A.G., Wien/UE 35958

$\mathrm{Na}$ figura anterior, verificam-se as seguintes informações do processamento eletroacústico referentes à voz: o número 3 circulado indica o terceiro evento eletroacústico; o retângulo logo ao lado mostra o harmonizer $(\mathrm{H})$, indicando apenas que a sequência (lista) de transposições da voz a partir deste trecho se alternará entre uma terça menor abaixo (3-) e a própria altura escrita sem qualquer transposição (0). Ou seja, além da voz amplificada, em certos momentos será adicionada na difusão eletroacústica uma terça menor abaixo, que por vezes será suprimida ao longo deste terceiro evento. O manual técnico nos revela em mais detalhes o que significa este terceiro evento (cue 3):

Figura 30 - Terceiro evento eletroacústico (cue 3) em Altra voce

\section{Cue 3}

Harmonizer: $\mathrm{H} 3-\downarrow, 0$

\begin{tabular}{|c|c|}
\hline interval (cent) & duration $(\mathrm{sec})$ \\
\hline-300 & 2 \\
\hline 0 & 3.5 \\
\hline-300 & 1 \\
\hline 0 & 3 \\
\hline-300 & 1.5 \\
\hline 0 & 5 \\
\hline-300 & 2 \\
\hline 0 & 3 \\
\hline
\end{tabular}

O evento corresponde à sequência de transposições que será aplicada à voz. Observe que haverá uma transposição inicial terça menor abaixo (-300 cents) que durará 2 segundos; em seguida suprime-se a nota transposta por 3,5 segundos; volta-se a adicionar a terça menor por 1 segundo, e assim por diante, constituindo uma sequência automatizada de transposições que durará 21 segundos.

Fonte: Luciano Berio “Altra Voce” (c) Copyright 1999 by Universal Edition A.G., Wien/UE 35958 
Ocorrerá, portanto, uma ampliação do corpo instrumental pelo processamento eletroacústico, já que são, de tempos em tempos, adicionadas ou suprimidas transposições predeterminadas. Vejamos na prática o que ocorre em termos harmônicos com a mezzosoprano neste evento 3:

Figura 31 - Modelo da primeira sequência de transposições da peça (Cue 3, harmonizer)

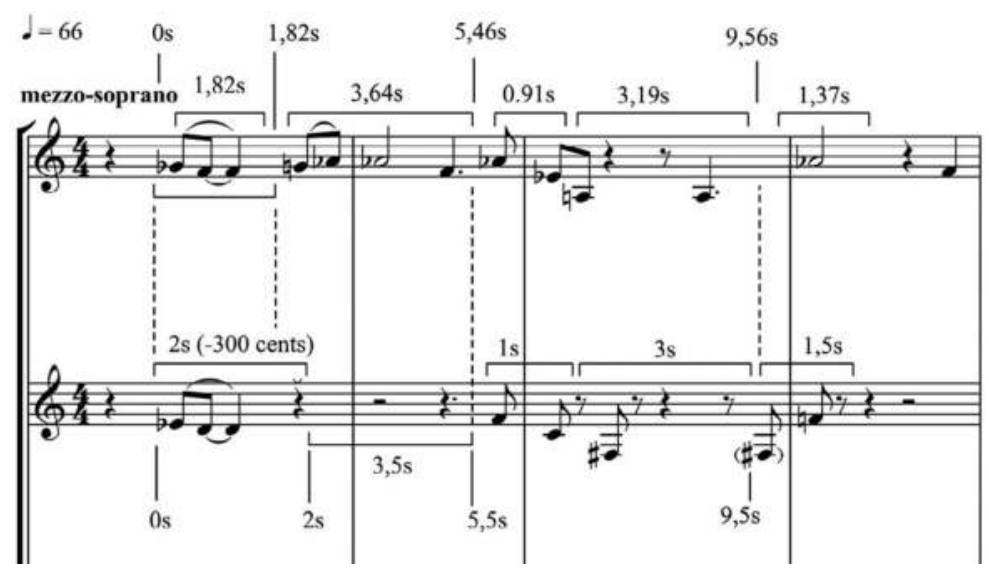

A pauta inferior foi elaborada aqui para efeito de visualizacão do que ocorre por conta do harmonizer. Embora o andamento seja 66 para a semínima (pouco menos de 1 segundo por unidade, portanto) e a duração de cada transposição esteja em segundos, repare que há momentos de encontro ou sincronização aproximados, representados acima pela primeira, terceira e quarta linhas verticais pontilhadas.

Fonte: elaborada pelo autor

O efeito prático do harmonizer introduz um tipo de anamorfose por adição instrumental extremamente rica de possibilidades, já que há um controle "nota-a-nota" em relação à expansão harmônica da peça. É claro que, quanto maior a complexidade dessas adições artificiais, maiores os desafios de realização e as imprevisibilidades da performance, já que o técnico deve seguir com relativa precisão os intérpretes de maneira a evitar resultados indesejáveis em termos harmônicos. As diversas reelaborações da escritura eletroacústica da peça podem ser um indicativo da dificuldade em ajustar com 
precisão esses detalhes na performance. Como quer que seja, o surgimento pontual e muito controlado de novas alturas no corpo instrumental constitui, por sua sutileza e fusão, um aspecto que torna Altra voce rica em anamorfoses.

- Live sampling/playback de fragmentos tocados: gravação em tempo real de trechos específicos da partitura e posterior reprodução em diferentes contextos. Há duas indicações técnicas que revelam como proceder na performance: RS (record sample), momento delimitado para gravação do que é executado pelo instrumento ou pela voz, e PS (play sample), designado a reproduzir o material sampleado. Há apenas um momento na peça em que o PS (PS 8) representa reprodução de sons pré-gravados (tempo diferido).

- Espacialização sonora: esquemas específicos de trajetórias que devem ser realizadas entre os alto-falantes. Existem trajetórias preestabelecidas em todos os eventos eletroacústicos, ou seja, a mobilidade espacial sempre acompanha algum dos processamentos recém-mencionados. Veja a figura seguinte com a disposição dos alto-falantes exigida para a performance:

Figura 32 - Disposições dos oito alto-falantes para a performance de Altra voce
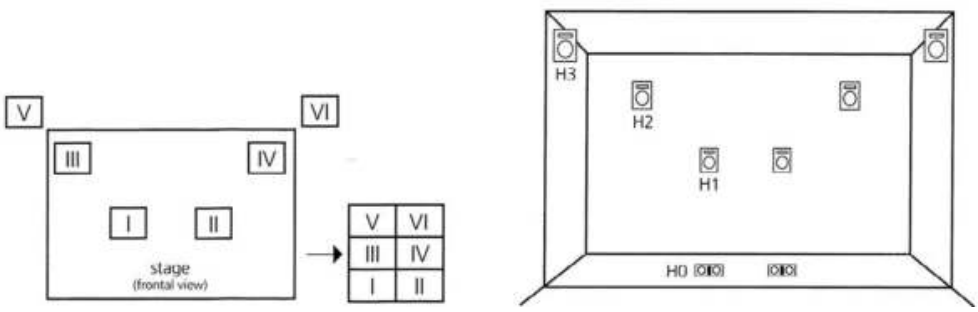

Seis são elevados (pares H1, H2 e H3) para a projeção dos sons eletroacústicos e dois (par H0) para a amplificação geral da voz e flauta.

Fonte: Luciano Berio "Altra Voce” (c) Copyright 1999 by Universal Edition A.G., Wien/UE 35958 
De maneira semelhante ao que ocorre com a entrada de dados do harmonizer, a automação das trajetórias espaciais segue uma lista de valores para cada evento eletroacústico, em uma tabela que especifica "ts" (tempo do sinal estacionário quando permanece em apenas um alto-falante) e "tm" (duração da trajetória do sinal de um alto-falante a outro):

Figura 33 - Esquema da automatização das trajetórias entre alto-falantes no evento eletroacústico 2

Cue 2

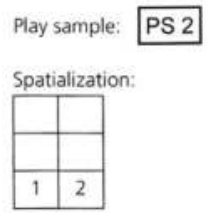

\begin{tabular}{|c|c|c|}
\hline Iocation & $\mathrm{t}_{\mathrm{s}}(\mathrm{sec})$ & $\mathrm{t}_{\mathrm{m}}(\mathrm{sec})$ \\
\hline 1 & 2 & 0.5 \\
\hline 2 & 3 & 0.5 \\
\hline 1 & 2 & 0.8 \\
\hline 2 & 1 & 0.1 \\
\hline
\end{tabular}

Move-se os sons originados no processamento apenas entre os alto-falantes 1 e 2 (par H1); o som permanece inicialmente por dois segundos no alto-falante 1 , em seguida passa ao alto-falante 2 em meio segundo, e assim por diante.

Fonte: Luciano Berio "Altra Voce” (c) Copyright 1999 by Universal Edition A.G., Wien/UE 35958

Figura 34 - Evento eletroacústico 2, que indica trajetórias entre os alto-falantes 1 e 2

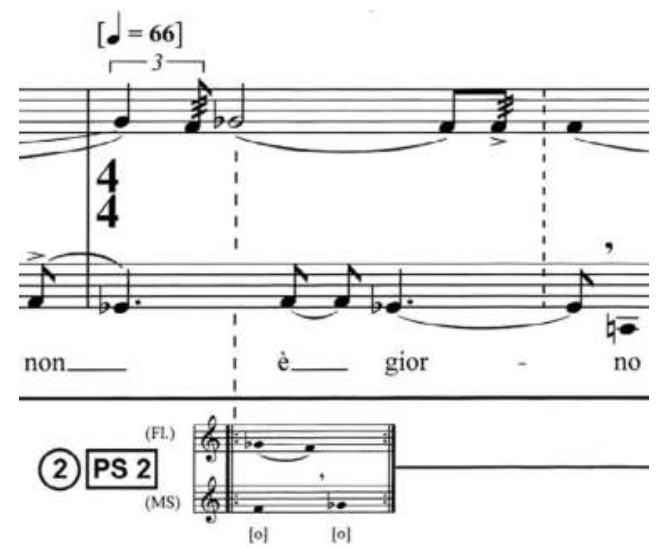

O evento dura cerca de dez segundos e é aplicado ao sample 2 reproduzido ao longo de uma grande parte da peça (até a seção E) - tanto o sample quanto a sequência de espacialização a ele aplicada são colocados em loop para ocupar todo o trecho.

Fonte: Luciano Berio "Altra Voce” (c) Copyright 1999 by Universal Edition A.G., Wien/UE 35958 


\section{Plano formal ${ }^{42}$}

Existem indicações na partitura (uma introdução e letras de A a I) que delimitam dez segmentações pelo compositor. Estas segmentações, por sua vez, obedecem a um plano mais geral conforme mostrado a seguir, constituído por uma Introdução (Prólogo), Primeira Parte, Segunda Parte, e um Epílogo. A seguir pode ser vista a distribuição do texto ao longo de cada uma destas seções. As repetições e a fragmentação imposta ao texto mostram a preocupação de Berio - aliás, marca de sua produção vocal ${ }^{43}$ - em amalgamar a voz, equipará-la ao instrumento no desenvolvimento musical.

\section{Introdução (Prólogo): 19 compassos}

non / non è giorno / non è giorno nè notte / non è giorno nè notte / nè notte un suo / un suono di tromba, quasi / quasi / quasi / quasi un suono

\section{Primeira Parte}
A: 13 compassos
di flauto, qua / quasi
di voce / di voce
di vento / di vento
vie / vieni
apri gli occhi / apri gli occhi
B: 10
ascolta / ascolta
non / non è / non è giorno nè notte

42 Giomi e Schwoon (2005) revelam que, à parte a introdução (Prólogo) e o trecho final (Epílogo), compostos posteriormente, as demais seções de Altra voce foram diretamente extraídas de Cronaca del Luogo.

43 Muito embora estas quebras do texto não ocorram de maneira radical como, por exemplo, em Circles (1960), para voz feminina, harpa e dois grupos de percussão. Isto, porém, é resultado do caráter geral e, obviamente, da natureza do texto de e. e. cummings em Circles e de Pecker Berio em Altra voce. 
C: 15

un suono di tromba, quasi

un suono / quasi un suono di flauto, quasi

di / di mare e di vento

D: 17

di voci / di voci/ di voci / di voci / di

di vento

vieni / vieni / vieni

apri gli occhi / apri gli occhi / apri gli occhi

\section{Segunda Parte}

E: 16

ascolta

il vecchio piange

padre e figlio

sono caduti sui monti / sui monti

F: 16

sento un'altra voce

vieni / vieni / vieni / vieni / vieni

vie / vieni

apri / apri / apri gli occhi

$\mathrm{G}: 17$

ascolta / ascol / ascolta

Epílogo (coincide com o evento eletroacústico 23, compasso 110)

un suono di flauto / un suono / quasi / quasi

di vo / di voce / di vo / di voce e di vento

$\mathrm{H}: 18$

di vento

ascolta / ascol / ascolta / ascolta

sento / sento / sento

I: 11

un'altra voce / un'altra voce

voce

vieni 
Em termos harmônicos, nota-se uma forte polarização do fá natural desde o início; trata-se de um centro do qual se proliferam outras alturas, em um caminho que parte da segunda menor (sol bemol) e atinge o intervalo extremo de décima menor entre lá e dó; esta correspondência com a terça menor não é casual, já que este intervalo é preponderante na estruturação de toda a peça ${ }^{44}$ - ver, por exemplo, que a primeira transposição realizada pelo harmonizer é de uma terça menor. $\mathrm{O}$ trecho da partitura correspondente à letra I da peça realiza um caminho contrário: reduz a densidade geral até atingir novamente o uníssono em um lento processo de filtragem.

Em um nível mais global, há uma clara articulação e um redirecionamento formal a partir da letra $\mathrm{E}$, quando retorna uma referência explícita à primeira segmentação da peça (letra A, logo após a Introdução, reproduzindo inclusive o mesmo sample daquele momento no evento eletroacústico), marcando o início da segunda parte da obra.

A figura seguinte condensa os 19 primeiros compassos da peça, pertencentes à Introdução, mostrando esta proliferação inicialmente muito fechada em termos intervalares, havendo uma abrupta irrupção com a chegada ao lá natural grave (lá 3), retomando o agrupamento bastante próximo ao fá 4 logo em seguida:

44 Segundo Flo Menezes, a terça menor é um intervalo preponderante em diversas obras de Berio: "Salvo raras exceções, quando o intervalo de segunda maior adquire um papel estrutural - Sequenza VIII (1975), para violino -, ou quando o discurso se polariza sobre uma única nota - o Si na Sequenza VII (1969), para oboé, ou o Si b na Sonata para piano (2001), uma das suas últimas obras -,é a terça menor o intervalo preferencial de Berio". Buscando ainda uma razão de origem acústica, Menezes revela que "de acordo com a variação da fundamental, os formantes podem, eles também, variar, e tal variação se restringe geralmente ao âmbito da terça menor - como observou Carl Stumpf”. Em nota, o autor comenta ainda que Berio teria plena consciência deste fato, "como quando ele define a terça menor como âmbito de extensão possível da fala simulada no começo do quarto movimento da Sinfonia (1968-69) ("sons randômicos simulando uma fala muito rápida', no âmbito da terça menor do4-mi b4)" (Menezes, 2013, p.1099 in Donin; Feneyrou, 2013, p.1095-120). 
Figura 35 - Redução harmônica da introdução (19 compassos) de Altra voce
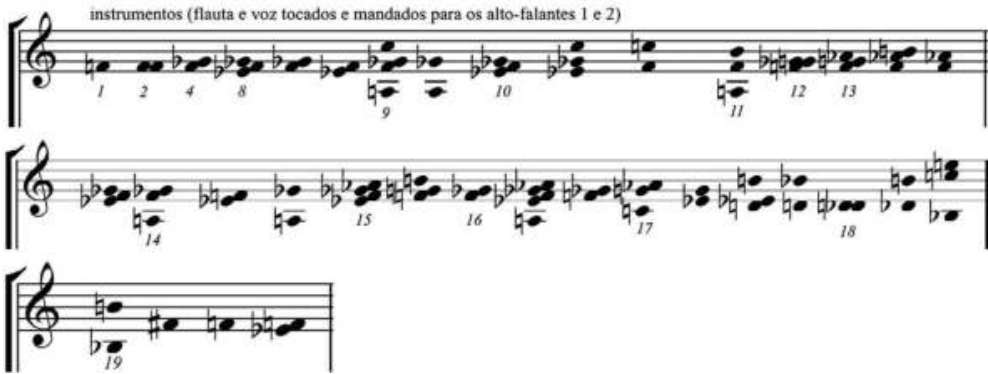

Fonte: elaborada pelo autor

Não são consideradas as adições eletroacústicas. Os números em itálico representam os compassos.

A introdução mostra esta proliferação bastante gradual de alturas a partir do fá 4, além de um leve direcionamento ao registro agudo. Além disso, e embora ainda não fosse possível avaliar pela Figura 35, existe, como já mencionado, um contraponto entre flauta e voz que é intensificado nesta seção não somente pela escritura instrumental, mas também pelas adições graduais de materiais sampleados (adição instrumental).

Além desta propagação harmônica que se inicia e retorna ao fá 4 na Introdução, Berio faz transitar contínua e intensamente entre flauta, mezzosoprano e contraparte eletroacústica alturas iguais. O uníssono ${ }^{45}$ contribui, assim, para uma rica variação de timbre ao longo de toda a peça e, especialmente se combinado às adições eletroacústicas, intensifica as anamorfoses e valoriza a continuidade entre harmonia e timbre como um fator decisivo da obra.

Se em Parcours de l'Entité vimos que o ataque inicial conglomerava duas referências instrumentais antagônicas (o ataque metálico e o som de flauta), Altra voce sintetiza, de maneira similar com seu primeiro evento eletroacústico, a fusão entre os próprios sons da voz

45 O uníssono pode sofrer modulações de timbre tanto no mesmo instrumento quanto no ir-e-vir de partes instrumentais que eventualmente o formam. 
Figura 36 - Os mesmo 19 compassos da introdução com a intervenção dos eventos eletroacústicos
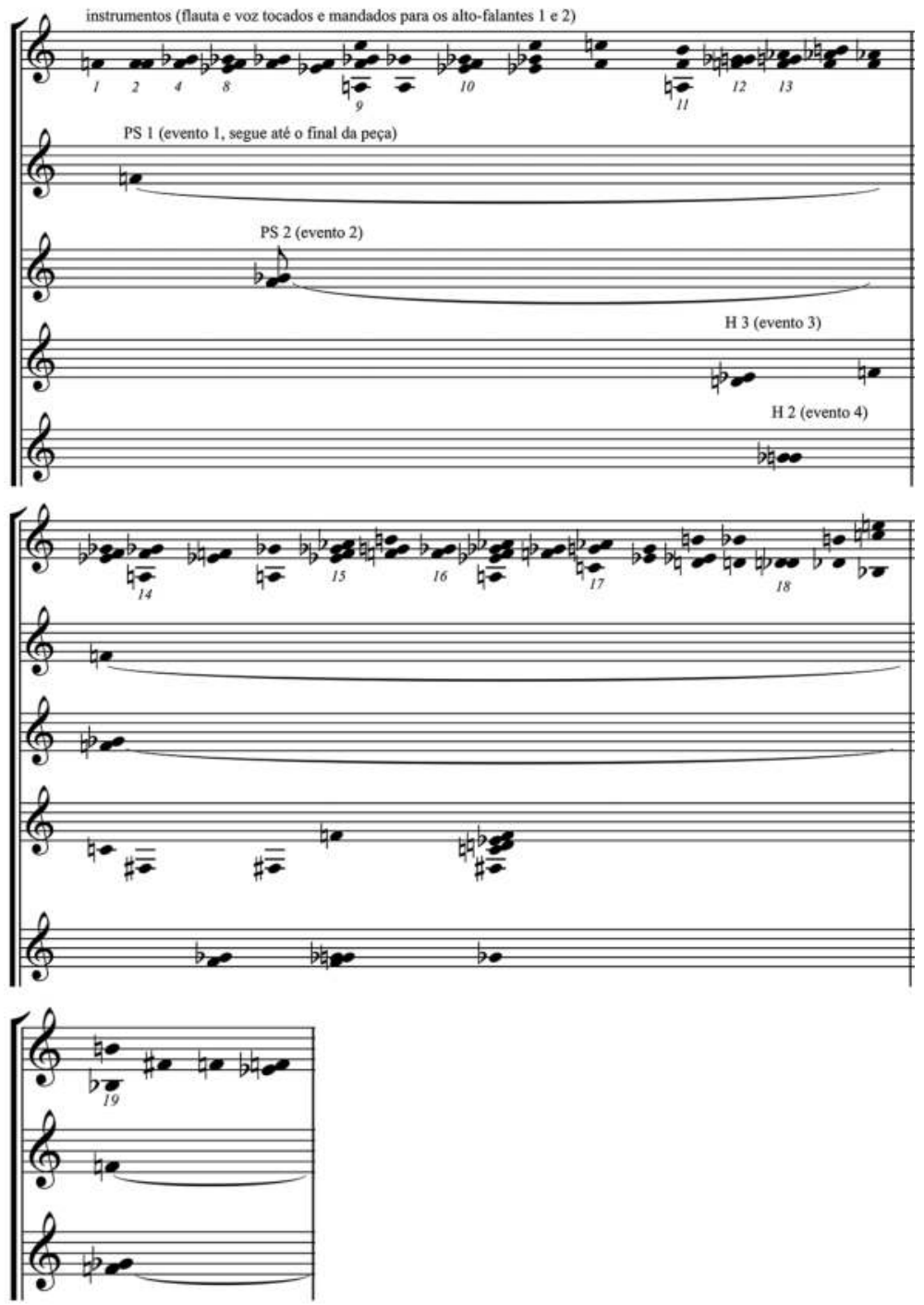

Fonte: elaborada pelo autor 
e da flauta em um "corpo único". Aqui, no entanto, a anamorfose não ocorre na "torsão" de um evento sonoro para promover uma "mudança de rumo" em seu envelope dinâmico, como em Parcours de l'Entité, mas antes na situação de fusão espectral. A ambiguidade já presente na fusão entre os sons de flauta e de voz, enfatizada e expandida pelos meios eletroacústicos, reflete fortemente um "quase-ser" constante no texto de Pecker Berio, personalizado pela "outra voz", uma dualidade entre a presença e a não presença.

A tabela seguinte, elaborada por Giomi e Schwoon, mostra de maneira interessante a organização formal da obra incluindo os eventos eletroacústicos: além das duas grandes seções da cena $\mathrm{Il}$ Campo, Berio compõe para Altra voce um Prólogo e um Epílogo. Vê-se, por exemplo, a rarefação textural que ocorre no início e no final da peça, assim como no início da segunda parte (denominada por eles $\mathrm{CdL} / \mathrm{b}$, em referência à segunda parte da cena Il Campo de Cronaca del Luogo) e do Epílogo. Especialmente no final da Segunda Parte ocorre a maior densificação de estratos diferentes na obra: três samples (campioni) diferentes sendo reproduzidos, três eventos simultâneos de processamento na flauta e dois eventos simultâneos de processamento na voz - lembre-se ainda que cada um destes eventos abarca trajetórias específicas de espacialização. A passagem ao Epílogo, última seção da peça, é evidenciada assim por uma forte articulação formal.

Tabela 5 - Tabela sintética elaborada por Giomi e Schwoon (2005) sobre as sobreposições dos eventos eletroacústicos de Altra voce, representados pelos números sequenciados

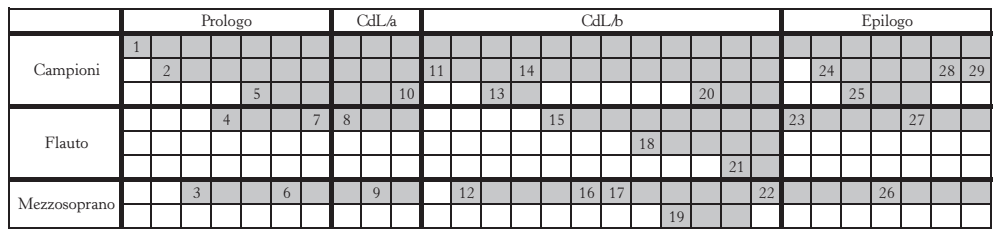

A divisão formal proposta, representada na linha superior, inclui as siglas CdL/a e CdL/b, já que os autores partem da divisão formal da cena Il Campo de Cronaca del Luogo, em duas partes, e a inserem juntamente com o prólogo e o epílogo adicionados por Berio em Altra voce. 
É fundamental a importância que a espacialização via alto-falantes adquire para permitir e clarear os momentos de adensamento polifônico - da mesma maneira que a estratificação em camadas múltiplas é realizada com frequência na música acusmática -, tornando-se um recurso que redefine a própria polifonia ao romper os estratos no relevo do espaço da performance.

O evento eletroacústico 11 (PS 3, próximo ao início da segunda seção formal) revela, pela repetição da estrutura intervalar do trecho, um aspecto fundamental da poética beriana: a cor, obtida pela ênfase em determinados intervalos, termo que também surgiu no discurso de Menezes durante a análise de Parcours de l'Entité. Ao eleger determinados intervalos preponderantes em aglomerados harmônicos, criam-se características harmônicas capazes de "impregnar o ouvido”. Vejamos um curioso diálogo de Berio com Luca Francesconi em que é mencionada esta questão:

Num certo dia o questionei de modo improvisado (estávamos em um automóvel indo em direção à Umbria para uma execução de A-Ronne): “...aquele belo acorde ao início da Sinfonia, com qual critério você o construiu?" E, com um olhar fulminante, Berio disse: “ACORDE??? Aquilo não é um acorde, é uma COR!!!”. Senti-me um idiota que troca a esquerda pela direita. Mas que diabos ele quis dizer??" (apud Menezes, 2014) $)^{46}$

46 No original: "Un giorno all'improvviso gli domandai (eravamo in automobile, diretti in Umbria per una esecuzione di A-Ronne) '...ma quel bellissimo accordo all'inizio di Sinfonia, mmm, con che criterio l'hai costruito ?...' Lui mi fulminò con lo sguardo e disse 'ACCORDO ??? quello non è un accordo, è un COLORE !!!'. Mi senti come un idiota che aveva scambiato la destra per la sinistra. Ma che diavolo voleva dire??". 
Figura 37 - Evento eletroacústico 11 (a letra E na partitura marca o início da segunda seção formal), entrada do material sampleado 3

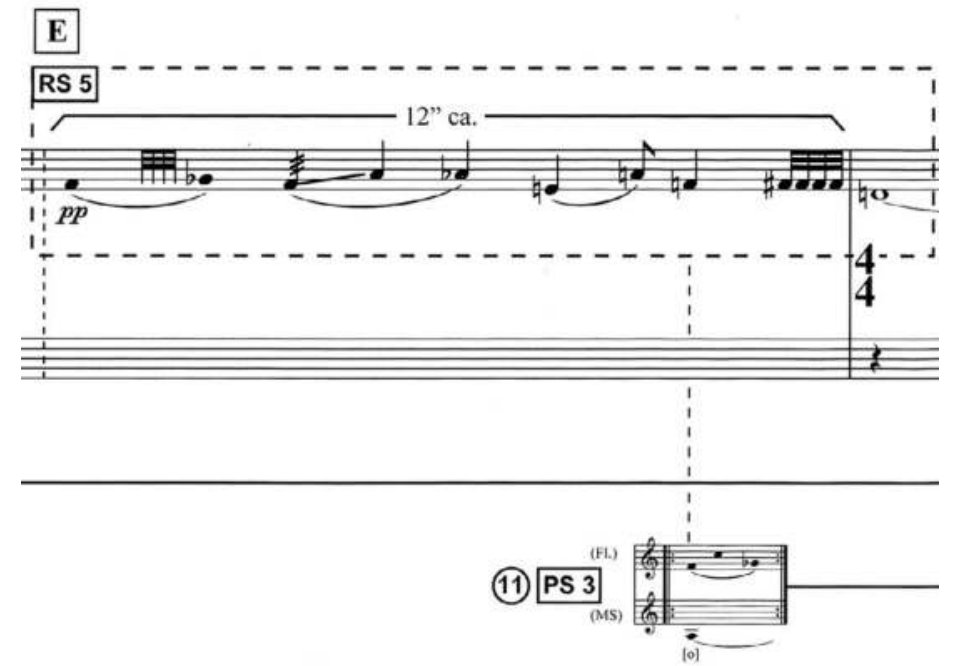

Fonte: Luciano Berio “Altra Voce” (c) Copyright 1999 by Universal Edition A.G., Wien/UE 35958

Embora este aspecto da preponderância de intervalos já ocorresse com a reprodução e repetição em loop do sample anterior (PS 2), a ênfase era restrita ao intervalo de $2^{\mathrm{a}}$ menor (fá - sol bemol). A estrutura intervalar do sample 3 (ver figura anterior) é um pouco mais complexa, e isto nos mostra um fato importante: até aqui, o compositor focou mais no aspecto de caracterizar uma cor harmônica, desde estabilizar a polarização inicial em fá até a repetição da estrutura intervalar do sample 3. É a partir do sample 4 que a adição instrumental passa a dialogar mais intensamente em termos de perfis melódicos com a execução ao vivo - embora invariavelmente mostre anamorfoses com respeito a diferentes timbres, suas mesclas e variâncias -, como é o caso do sample 7, reproduzido abaixo: 
Figura 38 - Evento eletroacústico 20, entrada do material sampleado 7

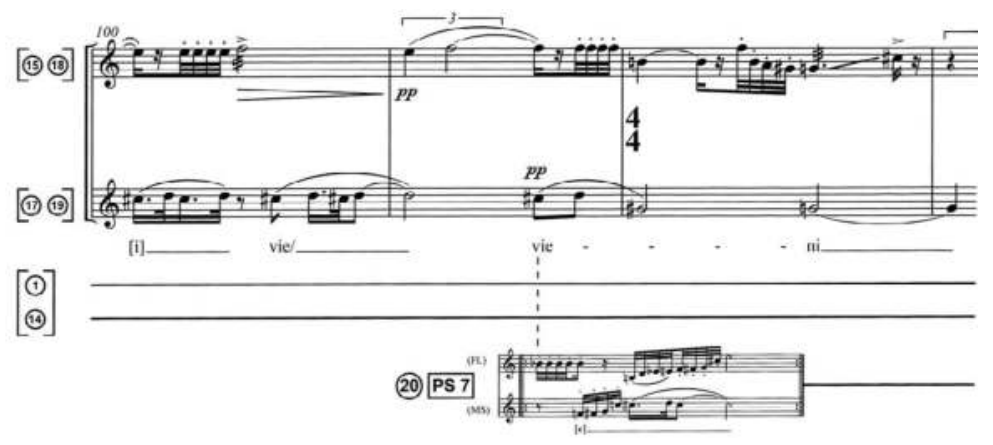

Fonte: Luciano Berio “Altra Voce” (C) Copyright 1999 by Universal Edition A.G., Wien/UE 35958

O evento 20 marca - com a iteração de notas e um perfil geral ascendente na esfera eletroacústica que, combinado à esfera instrumental executada ao vivo (completando inclusive o total cromático) - uma estrutura local bastante articulada e o início do trecho de adensamento máximo da peça. A furtiva presença de um lá 4 na flauta é curiosa (compasso 102): Berio faz uso desta altura quase exclusivamente e com maior ênfase no registro grave (lá 3), fortalecendo o intervalo lá 3-fá 4 como uma figura marcante no início e final da peça.

Segundo Giomi e Schwoon (2005, p.82), uma diferença substancial entre a primeira e a segunda parte, que se inicia com o evento eletroacústico 11 no compasso 75 (letra E da partitura), refere-se à adição do intervalo de quarta por meio do harmonizer: além de "conferir uma cor particular à segunda seção, [...] apresenta uma diferença com relação aos outros trabalhos com eletrônica de Berio como Ofanim e Outis, nos quais a harmonização é restrita ao âmbito da terça maior".

A elaboração harmônica adotada em Altra voce reporta a um procedimento comum em Berio, qual seja, incrementar pouco a pouco o campo de alturas até atingir o total cromático - veja-se novamente, por exemplo, a figura com a redução harmônica da Introdução, que completa o total cromático próximo ao final -, seguido ou 
permeado de uma valorização de um grupo de alturas preponderantes: no caso de Altra voce, notamos a partir do fá natural alguns intervalos bastante recorrentes -, constituindo uma prática comum em várias obras de Berio a partir dos anos 1960, como revela David Osmond-Smith. ${ }^{47}$

Observamos anamorfoses em Altra voce pelas ambiguidades geradas com as trajetórias dos sons processados em conflito com a amplificação dos instrumentos; por fusão espectral com o uso do harmonizer -inclusive em casos em que as transposições podem atingir alturas que não pertencem à extensão possível do instrumento ou $\mathrm{voz}^{48}$; e por adição instrumental, que também pode recair em casos de fusão espectral (como no início em PS1).

Muito embora a escritura eletroacústica da peça seja bastante voltada ao universo da sonoridade instrumental, causando anamorfoses ora pela fusão entre os sons executados ao vivo com os estratos eletroacústicos, ora pelo conflito (contraste) causado pela adição instrumental frente à presença da voz e da flauta, o uso do harmonizer traz outro traço marcante que caracteriza a dimensão eletroacústica enquanto ampliação da esfera instrumental. Giomi e Schwoon (2005, p.83) nos mostram de maneira muito clara como esta ampliação difere, no caso específico do harmonizer, de uma ampliação harmônica hipoteticamente realizada pela adição "real" de outras flautas e outras vozes no ensemble:

O entrelaçamento de linhas gerado com a harmonização eletrônica resulta sensivelmente diverso de uma estrutura realizável hipoteticamente com instrumentos acústicos: enquanto na presença de duas flautas reais (ou duas vozes) que soam juntas os componentes de um intervalo se diferenciam acusticamente graças às microflutuações individuais de cada som, no caso do instrumento

47 David Osmond-Smith (1991, p.26) nos atenta para este fato expondo o caso da Sequenza VII para oboé (1969).

48 Isto representa um paralelo curioso com o final de Parcours..., como mostrarei ainda, em que vemos um instrumento sendo tocado (flauta em dó) e ouvimos o som de outro via alto-falantes (flauta-baixo em dó), 
com harmonizer o som resultante é muito mais homogêneo, graças ao sincronismo artificial das flutuações. ${ }^{49}$

Em Altra voce, portanto, o papel da esfera eletroacústica não é trazer contrastes radicais com o corpo instrumental presente; trata-se, em especial, de expandir o universo instrumental de maneiras que, embora sutis em termos de alterações morfológicas dos sons, não deixam de enfatizar a presença do gesto acusmático, como visto com o uso do harmonizer.

49 No original: "L'intreccio di linee generato con l'armonizzazione elettronica risulta sensibilmente diverso da una struttura realizzabile ipoteticamente con gli strumenti acustici: mentre in presenza di due flauti reali (o due voci) che suonano insieme le componenti di un intervallo si differenziano acusticamente grazie alle micro-fluttuazioni individuali dei singoli suoni, nel caso dello strumento con harmonizer, il suono risulta molto omogeneo grazie al sincronismo artificiale delle fluttuazioni”. 


\section{4 \\ Abertura}

\section{Segundo aspecto das anamorfoses na música eletroacústica mista: a cena da performance}

O gesto do alto-falante associa-se a uma virtualização da informação sonora, a uma distância de seu referencial visual. Esta distância não se limita, por certo, a uma recontextualização desta informação, seja no deslocamento do espaço físico (dinamização de trajetórias), seja no tempo (reinserção de um evento sonoro em momentos posteriores). A distância habita o próprio material sonoro, esfacela a noção de um corpo associado a ele, torna-o autônomo, torna-o imagem. Neste âmbito dos materiais, as anamorfoses surgem das ambiguidades, das contradições, dos momentos em que somos surpreendidos com uma mudança de rumo diante do que acreditávamos ouvir, não só pela origem da fonte emissora, mas por possíveis desvios aplicados a objetos sonoros cujas trajetórias energéticas nos pareciam familiares.

Na passagem da música acusmática para a música mista, a presença humana é posta em evidência: estas distorções adquirem força em virtude do gesto instrumental - as ações vinculadas ao som produzido pelo corpo frente ao qual estamos e as ações vinculadas ao movimento que vemos produzir o som que ouvimos. $\mathrm{O}$ gesto 
instrumental é contraposto, portanto, a um universo eletroacústico que tem a potencialidade de transfigurá-lo. Eis então a abertura a que se propõe este capítulo: identificar um campo de anamorfoses que extrapola o nível do material, apontando para um encaminhamento e aprofundamento de pesquisas futuras envolvendo a performance da música mista.

A problemática descrita dá margem a poéticas composicionais que podem, desta forma, valorizar estas ambiguidades não só por meio do material musical em si, ou seja, pelos conflitos gerados na interação entre o corpo instrumental presente e a esfera eletroacústica, pela fusão e pelo contraste, mas também por meio de signos e funções não estritamente musicais atribuídos pelo compositor aos intérpretes para a performance, intensificando as distorções por elementos visuais. A partir daí, seria possível expandir a noção de anamorfose, que passaria a compreender, genericamente, as ambiguidades audiovisuais típicas da performance da música mista.

Em Parcours de l'Entité (Menezes), o aspecto cênico assume não somente uma grande importância nos momentos de articulação formal, ${ }^{1}$ mas também surge como ênfase a distorções no gesto instrumental: há um "jogo ilusório" na performance entre a ação dos intérpretes e o que é projetado pelos alto-falantes, que por vezes reflete sons pré-gravados provenientes dos próprios instrumentos, por outras apenas situações de similaridades (transferências) espectrais entre as duas esferas do material. Em suma, além das sete posições referentes ao percurso do flautista pelo palco, há três indicações cênicas na partitura que realçam a interação do intérprete com a eletrônica:

1) Já na página 2 da partitura, o flautista não só "realiza o mesmo som" do estrato eletroacústico - um "sopro grave" na flauta-baixo -, ligeiramente deslocado temporalmente, como

1 Sempre que ocorrem, esses gestos fazem referências a pontos estruturais importantes da obra. 
também é solicitado a olhar para o instrumento como se o "estivesse limpando através do sopro".

2) No início da terceira seção, o percussionista realiza um "gesto exagerado, como se fosse tocar o gongo grave e cloche-plaque $f f f$, mas na realidade toca $p p p$ " (página 6 da partitura), permanecendo imóvel até o fim da obra, buscando evidenciar o novo universo sonoro proposto pelo compositor (sons de síntese projetados pelos alto-falantes).

3) O gesto final da obra é muito representativo: o flautista deve simular produzir um longo e intenso sopro através do tubo da flauta, quando na realidade são os alto-falantes que concretizam o som referente a este gesto (o flautista mantém-se em silêncio). Aí há uma convergência entre o movimento do intérprete e a trajetória energética do som de sopro projetado pelos alto-falantes, desnuda-se visualmente a ação provocativa em direção ao público que ocorre durante toda a peça: o compositor optou pelo uso da flauta em dó, quando os alto-falantes difundem um som a partir da flauta-baixo em dó:

Figura 39 - Gesto final de Parcours de l'Entité

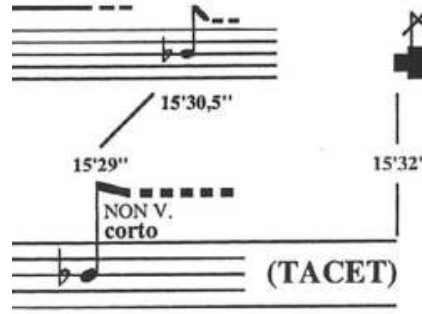

$p p$ pendant le dernier son de souffle dans la bande numérique, le flútiste fait un geste de souffle exagéré, en silence, en accompagnant le son de la bande dans l'espace, de gauche à droite

\section{São Paulo, février/mars 1994}

O compositor indica na partitura a atuação cênica do intérprete, que deve realizar "um gesto de sopro exagerado, em silêncio, acompanhando o som projetado no espaço, da esquerda para a direita".

Fonte: Menezes (1998). 
O aspecto audiovisual mostra-se, assim, um campo fértil de ambiguidades na música mista, podendo contribuir para construções formais diferenciadas, que trabalhem com elementos extramusicais, tendo nos meios eletrônicos um catalisador para estas veredas possíveis. A última ação de Parcours... revela-se extremamente sintomática, já que da simulação do intérprete "resulta", aos olhos e ouvidos do público, um som mais grave que a extensão própria do instrumento. Aí, um único gesto, que apesar de "conclusivo" em termos figurais, relacionais - o "sopro grave" é um forte elemento estrutural da peça -, deixa na ilusão da cena um questionamento crucial na obra eletroacústica que é potencializada na música mista: a anamorfose no gesto instrumental, mas uma anamorfose que resulta não somente de um processo de distorção aplicado ao som da flauta em dó; ela surge com todo vigor, isto sim, com a própria cena. Pode-se auscultar se o som da flauta foi processado ou se foi combinado ao estrato eletroacústico para resultar no que é ouvido. Enfim, não se tem ao certo o que causou ou qual processo de transformação sofreu aquele som a não ser que se acompanhe a partitura ou saiba de antemão o que ocorrerá.

O gesto cênico compõe mais um "percurso" por meio da mobilidade do flautista pelo palco, formando assim outro pilar da poética da obra. Há sete posições distintas determinadas pelo compositor, com três trocas de flautas: flauta em dó na posição 1; troca para a flauta-baixo em dó na posição 2; flauta-contralto em sol na posição 5; flauta em dó na posição 6. A amplificação das flautas nas posições 3, 4/7 e 5 é intensificada, de modo que o nível sonoro deve ser comparado ao dos sons eletroacústicos nestas posições, além do fato de que a amplificação da flauta obedecerá, no desenho do panorama espacial, à trajetória do flautista sobre o palco. Observemos na figura seguinte, extraída da partitura, como a amplificação contribui para a fusão e o contraste entre os sons da flauta e sua contraparte eletroacústica: a entrada sutil do instrumento no início da obra - ainda distante do microfone - valoriza a anamorfose presente no estado de fusão que ocorre neste momento (a flauta se "cola" furtivamente ao pedal eletroacústico em si bemol). Já na posição 7, que marca o início 
da terceira seção formal, o contraste entre as dimensões instrumental e eletroacústica é pronunciado; o nível da amplificação e a posição centralizada no palco polarizam o intérprete, equiparando o som ao vivo com os sons de síntese projetados pelos alto-falantes. Todas as mudanças de localização do flautista ocorrem na primeira seção (posições 1 a 5 ) e na transição (posições 5 a 7).

Figura 40 - As disposições espaciais do flautista conforme indicadas na partitura

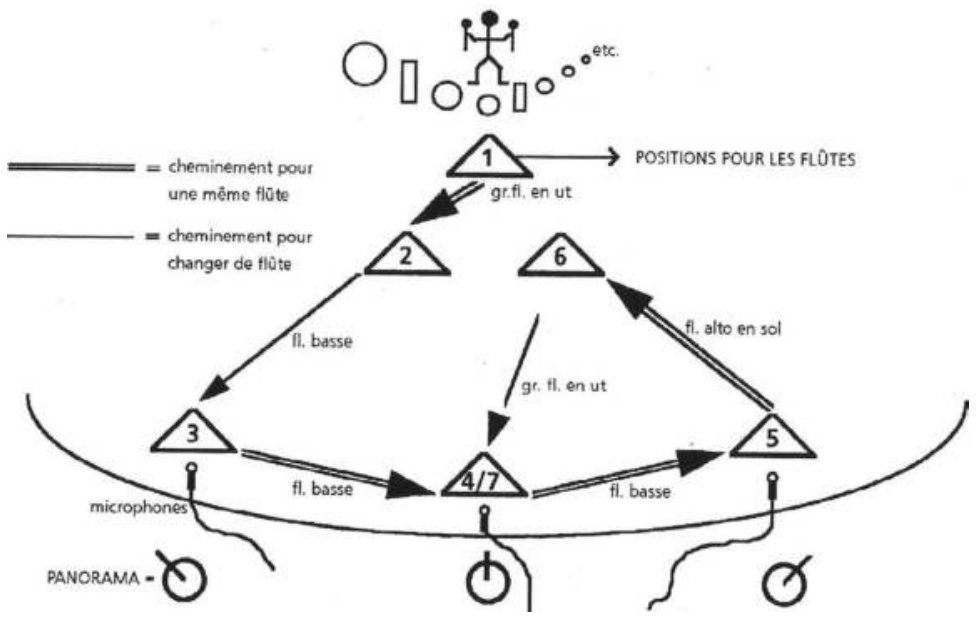

Fonte: Menezes (1998), partitura de Parcours de l'Entité

Parcours de l'Entité representa um caso típico da composição de "cenas" que podem enfatizar as anamorfoses na interação com meios eletroacústicos. Assim também identificamos a questão na ocultação visual de grupos de alto-falantes para a estreia de Outis, de Berio, e é possível observá-la ainda em outras obras mistas que fazem uso de elementos fortemente simbólicos na cena. O véu, representado metaforicamente em Outis pelo mascaramento dos alto-falantes, é o elemento que teria dado origem ao termo acusmática ao fazer referência à escuta sem a visão da fonte emissora. Este elemento pode ser observado em muitas obras como símbolo dos diferentes níveis de "translucidez" que a integração entre instrumentos e sons 
eletroacústicos pode instaurar, suas ambiguidades, que vão de uma maior permeabilidade e transparência até a opacidade, o contraste mais evidente.

Tal fenômeno ocorre em diversas obras mistas, cada qual com um viés distinto: em Trans, para orquestra (Stockhausen, 1971), em que um "véu" semitransparente deve cobrir completamente a frente do palco, havendo uma correspondência no material musical (uma "cortina" sonora por meio de um cluster variável nas cordas que atravessa toda a obra e encobre os sons dos demais grupos instrumentais); ${ }^{2}$ em ... of Silence (Marco Stroppa, 2007, para saxofone e eletrônica), em que o véu é opaco (uma espécie de totem de alto-falantes esconde o intérprete, e o que se vê na performance é apenas este elemento no palco, única fonte emissora visível de sons - a projeção é unicamente frontal); ${ }^{3}$ em Cronaca del Luogo (Berio, 1999), em que a muralha do Felsenreitschule revela uma correspondência com o "muro harmônico" referido por Berio, refletindo o relevo sonoro a partir da disposição verticalizada do coro e orquestra, controlado por sistemas informáticos; e, como uma última referência dentre muitas outras possíveis, em Colores (Phila: In Praesentia) (Menezes, 2000, para um clarinetista, um percussionista, som eletroacústicos em tempo diferido e em tempo real), em que, para a performance de 2011, circunstancialmente devido à apresentação de um vídeo experimental realizado por Branca de Oliveira e Fernando Saiki sobre a obra, uma tela semitransparente entre o público e o palco foi usada para projetar imagens que "confundiam" a atuação dos músicos.

No artigo "Formas do espaço na música eletroacústica mista”, mapeei alguns casos em que elementos de cena - iluminação, cenário, gestos cênicos do intérprete, entre outros - realçam o aspecto das anamorfoses nos materiais da música mista:

2 Esta questão é explorada por Wishart (1996).

3 Lembra-se aqui do comentário de Bruno Ruviaro acerca de sua obra Instantânea, sobre como o procedimento de concentrar os alto-falantes em uma espécie de "núcleo" próximo ao instrumento é também utilizado por Stroppa. 
Buscam-se nas obras mistas a serem estudadas elementos visuais que estejam longe de conter signos fortuitos, de uma pretensa dramaticidade desinteressada; a dinâmica da apresentação promoveria verdadeiras situações formais, inserindo mais um campo de significação na complexidade da obra, realçando a dualidade entre o visível e o invisível como uma problemática essencial da composição mista, convertendo-se em metáfora do confronto entre corpos presentes e imagens sonoras. A partir do momento em que o compositor prevê a inserção de situações e elementos visuais, o espaço da performance adquire, como potência, ${ }^{4}$ uma função proeminente na concepção formal: além do aspecto morfológico dos sons, sua dinâmica espectral, e das questões derivadas da estruturação do material em si, as disposições cênicas e a própria corporalidade do intérprete agregariam novos elementos de significação. (Gati, 2012, p.254-5)

A abertura no que se refere às formas musicais, especialmente a partir dos anos 1950 em diante, assim como a proliferação de caracteres cênicos requisitados para as performances - afastando-se, no entanto, da linearidade narrativa da ópera -, encontra paralelos interessantes e termos comuns tanto na música quanto no teatro. Menezes adota um termo para abarcar o aspecto cênico da performance ao qual estamos nos referindo: a situação. ${ }^{5}$ Em entrevista realizada com o compositor em novembro de 2011, discutiu-se a questão das articulações formais em sua obra e constatou-se que esta noção já estava presente em Parcours..., mas viria a ser propriamente elaborada em um momento posterior, especialmente com labORAtorio (1991;

4 Vale a menção de que esta hipótese não invalida a escuta de uma obra assim concebida sem que os elementos visuais estejam presentes. Ou seja, estamos falando de casos em que uma reprodução puramente sonora manteria a autonomia da obra pela estruturação do material musical em si. A performance, nesses casos, além de atualizar a obra, agregaria novos elementos visuais importantes para enfatizar anamorfoses particulares da música mista.

5 A situação é discutida, por exemplo, em Hegel (2001 [1835]) e Sartre (1992 [1973]), assim como, em música, em Tarasti (1998) e Menezes (2011). Mas é sobretudo em Menezes que o termo adquire um sentido mais apropriado para o nosso contexto. 
1995; 2003, para soprano, coro a cinco vozes, grande orquestra e eletrônica). A situação, verdadeira circunstância de ação musical, incorpora na performance em si elementos que aderem ao plano formal. Para a composição de Traces (2007, para quarteto de cordas e live-electronics), por exemplo, Menezes (2011b) afirma:

Minha intenção foi a de "explodir" o quarteto no espaço e no tempo, explorando os traços que se perfazem entre notas e suas ressonâncias, entre uma mesma entidade harmônica e suas metamorfoses, entre os sons e suas projeções no espaço, entre a inovação e inevitáveis referências clássicas do gênero [o quarteto]. A forma da obra estrutura-se em Situações, em que os músicos do quarteto se deslocam pelo espaço total do teatro.

Há um paralelo inevitável nesta circunstância situacional com a poética beriana referente à azione musicale, termo utilizado pelo compositor italiano Luciano Berio para obras em que a dimensão cênica integra o gesto musical, como em La vera storia (1977-81), Outis (1995-96) ou em sua última azione musicale, Cronaca del Luogo. Berio foi muito além do uso da dimensão cênica enquanto teatro "narrativo" propriamente dito, como caracterizado na ópera tradicional, e distanciou-se mesmo das poéticas que elegeram o teatro como elemento preponderante diante das estruturas musicais (tal como ocorre tipicamente na obra de Mauricio Kagel), investigando sua aplicação no seio das estruturas musicais. Consideremos uma citação do próprio compositor sobre a obra Circles (1960), que busca inserir e ampliar a dimensão cênica no gesto instrumental, contaminando-o com elementos extramusicais provenientes de ações cênicas atribuídas (no sentido da teoria da ação, movimento do performer repleto de significações mais ou menos sedimentadas):

Existem experiências de teatro instrumental e de teatro vocal que podem encontrar seu centro e sua coerência expressiva alternativamente em operações que gostaria de definir mais uma vez como "aditivas" ou "subtrativas". No primeiro caso, cada participante é 
envolvido por uma quantidade exorbitante de funções e de relações musicais que, somadas umas às outras, encontram expressão e refúgio na gestualidade, em uma espécie de "palavra cênica" da escuta. No segundo caso, o trabalho musical é violado, é reduzido a alguns detalhes de execução que, uma vez isolados, tendem a adquirir sua autonomia (respirar de distintas maneiras sem que, entretanto, se produza qualquer som, por exemplo), com o risco do anedótico, da paródia elementar e do kitsch.

Interessei-me pelo primeiro caso, o de executantes sobrecarregados por um excesso de trabalho, ou seja, por uma quantidade excessiva de funções musicais. Interessava-me também explorar as possibilidades de uma escuta privada de uma dramaturgia predisposta e radicada a priori na estrutura musical, e, ao invés disso, explorar uma dramaturgia deduzida e gerada pelos próprios processos musicais. É o caso dos meus primeiros passos, em 1961 e 1962, no território do teatro musical que eu não havia ainda explorado nem aprofundado, mas através do qual havia afinado meus instrumentos - de novo, como um recordar (a)o futuro - sobretudo através de minhas leituras de Monteverdi (Orfeo, Il Combattimento di Tancredi e Clorinda, o Oitavo Livro de Madrigais) e das implicações - mais que das realizações - dos madrigali rappresentativi, ou ainda do "teatro para os ouvidos" da última Renascença. Penso em meus já mencionados Circles sobre três poemas de e. e. cummings, para voz feminina, harpa e dois percussionistas; e em Visage para a mesma voz feminina (a de Cathy Berberian) e elaborações eletroacústicas; penso ainda em Passaggio para soprano, orquestra e dois coros: um na orquestra e outro espalhado pelo público.

A quantidade exorbitante de funções e de relações musicais em Circles (estreada em Tanglewood em 1960 com Cathy Berberian e solistas da Orquestra Sinfônica de Boston) pode ser descrita, em resumo, como se segue. As três poesias de e. e. cummings, de crescente complexidade, são repetidas duas vezes: I, II, III e III, II, I, em um total de cinco episódios musicais. O poema I é repetido, ao final de Circles, com elementos musicais do segundo episódio. $\mathrm{O}$ poema II é repetido com elementos do primeiro episódio, enquanto 
que o poema III, no terceiro episódio, repete a si mesmo em direção contrária. A harpa e as percussões expandem, pois, musical e acusticamente os três poemas de e. e. cummings pela maneira como estes são propostos pela voz: os poemas assumem o papel de geradores de funções musicais e/ou acústicas. É desenvolvida antes de mais nada uma contínua oscilação entre elementos periódicos, ligados a específicas famílias de intervalos facilmente perceptíveis, e eventos complexos caracterizados por um grau relevante de indeterminação. Os critérios de escolha e de uso da percussão e da harpa são determinados por modelos fonéticos específicos: os instrumentos ressoam, por assim dizer, a voz e as palavras. Ressoam diversos modos de ataque, vogais e consoantes (fricativas, sibilantes, explosivas etc.). Os instrumentos traduzem e expandem os comportamentos vocais como uma espécie de onomatopeia ou, melhor ainda, de bilinguismo vocal-instrumental. A relação entre uma voz feminina e dois percussionistas frequentemente encadeados um com o outro pode apresentar problemas de equilíbrio acústico. A cantora deve, pois, se deslocar, perfazendo sobre o palco um itinerário que lhe permita de vez em quando ser acompanhada pelos instrumentos, comportar-se como eles e, ainda, ser completamente assimilada por eles, tornando-se ela mesma um instrumento. Esta mobilidade de relação implica distintos modos e graus de perceptibilidade do texto. A fim de preservar e desenvolver um diálogo muito intenso entre as dimensões musical, fonético-acústica e espacial, faz-se necessária uma coordenação particular que é confiada a verdadeiras sinalizações musicais da parte de todos os executantes, além de gestos e sinais bem visíveis da cantora. E mesmo as sinalizações musicais e os gestos da cantora (a qual parece celebrar um rito de total identificação com os demais executantes) são assimilados pelo processo musical, de modo que Circles torna-se uma representação de uma superabundância de relações musicais e acústicas. A própria partitura torna-se uma entidade polivalente evocada, realizada e traduzida em comportamentos visual e musicalmente diversificados. (Berio, 2006, p.116-8. Tradução crítica de Flo Menezes do livro Remembering the Future, no prelo) 
As situações incorporam esses fatores mencionados por Berio na medida em que múltiplos níveis de significado são latentes na performance que incorpora elementos cênicos. E sendo a questão das anamorfoses uma problemática fundamental da música mista, estes elementos agregam outros campos de ambiguidades - seja realçando a fusão dos estratos instrumentais com os eletroacústicos, seja pelas desconexões furtivas presentes nos limites do seu contraste. Abre-se, desta maneira, um campo possível de investigações em casos representativos da problemática das anamorfoses na música mista aplicados ao campo da performance. Mais que isto, podem-se vislumbrar meios pelos quais os recursos eletroacústicos transfiguram o espaço na composição mista instaurando anamorfoses, em um confronto entre a presença e a não presença, em uma virtualização do gesto instrumental, radicalizada na cena da performance. Tal aprofundamento instiga, sobretudo, que esta investigação enverede para situações e contextos distintos, especialmente se acompanhados da realização composicional. 


\section{REFERÊNCIAS BIBLIOGRÁFICAS}

BAYLE, F. Musique Acousmatique. Propositions... ...Positions. Paris: INA e Éditions Buchet/Chastel, 1993.

BEAUCHAMP, J. An Introductory Catalogue of Computer Synthesized Sounds by Jean Claude Risset. Perspectives of New Music, v.9, n.2 - v.10, n.1 (Spring/Summer-Autumn/Winter, 1971), p.348-50.

BERIO, L. Two Interviews: with Rossana Dalmonte and Bálint András Varga. New York: Marion Boyars Publishers, 1985.

. Prospettive nella Musica: Ricerche ed Attività dello Studio di Fonologia Musicale di Radio Milano. Elettronica, n.2/3, anno XLVII, dez. 1998. . Remembering the future. Cambridge, Mass.: Harvard University Press, 2006.

. "Poesia e Música: uma experiência". (1959) In: MENEZES, F. Mú-

sica eletroacústica: história e estéticas. São Paulo: Editora da USP, 2009. [O texto de Berio foi traduzido da publicação em Incontri Musicale - Quaderni Internazionali de Musica Contemporanea, n.3, Milão, ed. Suvini Zerboni, ago. 1959. p.98-110].

. Scritti sulla Musica. Torino: Einaudi, 2013.

BOULEZ, P. Technology and the Composer. In: EMMERSON, S. (Org.). The Language of Electroacoustic Music. New York: Harwood Academic Publishers, 1986. p.5-14.

. A Música hoje. (1963) São Paulo: Perspectiva, 2002.

. No limite do país fértil: Paul Klee. In: MENEZES, F. (Org.). Música

eletroacústica: história e estéticas. São Paulo: Editora da USP, 2009. 
CAMPOS, A. Música de invenção. São Paulo: Perspectiva, 1998.

CHADABE, J. Electric Sound - The Past and Promise of Electronic Music. Upper Saddle River: Prentice Hall, 1997.

DANTO, A. A transfiguração do lugar-comum. São Paulo: Cosac Naify, 2005.

DE BENEDICTIS, A. I. A meeting of music and the new possibilities of technology. The beginnings of the Studio di Fonologia Musicale di Milano della RAI. In: NOVATI, M. M.; DACK, J. (Orgs.). The Studio di Fonologia: a Musical Journey, 1954-1983. Milano: Universal Music MGB, 2012.

DELIÈGE, C. (Org.). Cinquante ans de Modernité Musicale: de Darmstadt à L'Ircam. Sprimont (Belgique): Mardaga, 2003.

DIDEROT, D.; D’ALEMBERT, J. le R. (Org.). Encyclopédie, ou dictionnaire raisonné des sciences, des arts et des métiers. Tomo 4 - Arts et Métiers Mécaniques. Paris: André le Breton, 1785.

EMMERSON, S. (Org.). The Language of Electroacoustic Music. London: Macmillan, 1986. . Living Electronic Music. Hampshire: Ashgate, 2007.

Location-Dislocation-Relocation (Where is Live Electronic Music?). In: IV SEMINÁRIO MÚSICA CIENCIA TECNOLOGIA: Fronteiras e Rupturas. São Paulo: ECA-USP, 2012.

FENEYROU, L. (Org.). Musique et Dramaturgie - Esthétique de la représentation au XXe siècle. Paris: Publications de la Sorbonne, 2003.

FERNEYHOUGH, B. Collected Writings. Amsterdam: Harwood Academic Publishers, 1995.

FERRAZ, S. Música e repetição: a diferença na composição contemporânea. São Paulo: Educ/Fapesp, 1998.

FREIRE, S. Alto-, alter-, auto-falantes: concertos eletroacústicos e o ao vivo musical. São Paulo, 2004. Tese (Doutorado) - Pontifícia Universidade Católica de São Paulo.

GARNETT, G. E. "The Aesthetics of Interactive Computer Music”. Computer Music Journal, v.25, n.1 (2001), p.21-33.

GATI, T. Formas do espaço na música eletroacústica mista. In: SIMPÓSIO BRASILEIRO DE PÓS-GRADUANDOS EM MÚSICA, Anais. 2012, Rio de Janeiro. Anais... Disponível em: <http://www.unirio.br/simpom/>. GIOMI, F.; CREMASCHI, A. "“Parrrole”: ‘: Berio’s Words on Music Technology”. Computer Music Journal, v.28, n.1 (spring, 2004), p.26-36.

GIOMI, F.; MEACCI, D.; SCHWOON, K. "Live Electronics in Luciano Berio's Music”. Computer Music Journal, v.27, n. 2, p.30-46, 2003.

GIOMI, F.; SCHWOON, K. Il continuo mutevole: Altra voce di Luciano Berio. Rivista di Analisi e Teoria Musicale, n.2, ano XI, 2005, p.69-88. 
GOMBRICH, E. Mirror and Map: Theories of Pictorial Representation. Philosophical Transactions of the Royal Society of London, v.270, n.903, p.11949, mar.13, 1975. (Series B, Biological Sciences)

GRAU, O. Virtual Art: from Illusion to Immersion. Cambridge, Mass.: The MIT Press, 2003.

GRISEY, G. Did you say spectral? Contemporary Music Review, Overseas Publishers Association, v.19, n.3, p.1-3, 2000.

Écrits - ou l'invention de la musique spectrale. s. 1.: Éditions MF, 2008.

HARVEY, J. The Mirror of Ambiguity. In: EMMERSON, S. (Org.). The Language of Electroacoustic Music. London: Macmillan, 1986.

. Compositeurs d'aujourd'hui/Jonathan Harvey (Entretien). Paris:

l'Harmattan, Ircam, 2000.

HEGEL, G. F. Cursos de Estética I. São Paulo: Editora da USP, 2001.

LIGETI, G. Neuf Essais sur la Musique. Genève: Contrechamps, 2001.

MANNING, P. The Influence of Recording Technologies on the Early Development of Electroacoustic Music. Leonardo Music Journal, vol.13, p.5-10, 2003.

MATTIS O. Varèse's Multimedia Conception of Déserts. The Musical Quarterly, vol.76, n.4, p.557-83, 1992.

MENEZES, F. O que vem a ser o "sistema de polarização" - a segunda menor é o átomo do sistema tonal. In: Jornal "Viva há Poesia", São Paulo, 1979, p.5. . Luciano Berio et la Phonologie - Une Approche Jakobsonienne de son

Oeuvre. Frankfurt a.M./Paris/New York: Verlag Peter Lang, 1993.

. Atualidade estética da música eletroacústica. São Paulo: Editora Unesp, 1998.

. Apoteose de Schoenberg. Cotia: Ateliê Editorial, 2002.

. A acústica musical em palavras e sons. Cotia: Ateliê Editorial, 2003.

. Música maximalista. São Paulo: Editora Unesp, 2006.

Música eletroacústica: história e estéticas. São Paulo: Edusp, 2009

[1996].

O orolho e o ouver. Apresentação em slides da disciplina de pósgraduação em música realizada no Instituto de Artes da Unesp. Fonte: http:// www.flomenezes.mus.br/flomenezes/index_flomenezes.html, 2011a. . De Spectris Sonorum. DVD. São Paulo: Sesc, 2011b.

. Matemática dos afetos: tratado de recomposição musical. São Paulo: Edusp, 2013a.

Luciano Berio. In: DONIN, N.; FENEYROU, L. (Direction scientifique). Théories de la Composition Musicale au XX. Siècle, vol.2, Lyon (France): Symétrie, 2013b. p.1095-120. 
Nova Ars Subtilior-Essays zur maximalistischen Musik. Hofheim (Deutschland): Wolke Verlag, 2014.

MURAIL, T. After-thoughts. Contemporary Music Review, Overseas Publishers Association, vol.19, n.3, p.5-9, 2000.

. The Revolution of Complex Sounds. Contemporary Music Review, Overseas Publishers Association, vol.24, n.2/3, p.121-35, 2005.

OSMOND-SMITH, D. Berio. Oxford/New York: Oxford University Press, 1991.

Here comes nobody: a dramaturgical exploration of Luciano

Berio's Outis. Cambridge Opera Journal, v.12, n.2, p.163-78, 2000.

PAYTON, R. The Music of Futurism: Concerts and Polemics. The Musical Quarterly, v.62, n.1, p.25-45, 1976.

ROWE, R. Interactive Music Systems. Cambridge: The MIT Press, 1994.

RUVIARO, B. From Schaeffer to *LOrks: an expanded definition of musical instrument in the context of laptop orchestras. In: PROCEEDINGS OF THE $1^{\text {ST }}$ SYMPOSIUM ON LAPTOP ENSEMBLES \& ORCHESTRAS, Baton Rouge, Louisiana: 2012, p.23-6.

SARTRE, J.-P. Un Théâtre de Situations. Paris: Gallimard, 1992.

SCHAEFFER, P. Traité des Objets Musicaux. Paris: Seuil, 1966.

. Solfejo do objecto sonoro. Lisboa: s. n., 1996 [1967].

SHAKESPEARE, W. Hamlet, Prince of Denmark. London: Chancellor Press, 1993.

. Hamlet. São Paulo: Abril Cultural, 1976.

SMALLEY, D. Spectro-morphology and Structuring Processes. In: EMMERSON, S. The Language of Electroacoustic Music. New York: Harwood Academic Publishers, 1986.

. Sound diffusion in composition and performance: an interview with Denis Smalley. Computer Music Journal, v.24, n.2, p.10-21, 2000.

STRAVINSKY, I. Chroniques de ma vie. Paris: Denoël, 1962.

TARASTI, E. Les Situations comme espaces musicaux. In: CHOUVEL, J.-M., SOLOMOS, M. (Org.). L'espace: Musique/Philosophie. Paris: L'Harmattan, 1998.

TOOP, R. Stockhausen's Secret Theater: Unfinished Projects from the Sixties and early Seventies. Perspectives of New Music, v.36, n.2, p.91-106, 1998.

VARÈSE, Edgar. Novos Instrumentos e Nova Música (1936). In: MENEZES, F. (Org.). Música eletroacústica: história e estéticas. São Paulo: Edusp, 2009. WISHART, T. On sonic art. Reading (UK): Harwood Academic Publishers, 1996. 


\section{Partituras}

BERIO, L. Altra Voce, per flauto contralto, mezzosoprano e live-electronics (partitura). Viena: Universal Edition, 1999 (UE35958).

GATI, T. Nomoi, para violino e live-electronics (partitura). São Paulo: Edição do autor, 2013.

MENEZES, F. Parcours de l'Entité (partitura). São Paulo: Editora Unesp, 1998 (acompanha o volume Atualidade estética da música eletroacústica. São Paulo: Editora Unesp, 1998); publicado também por Edições Flopan, 2013. . Colores (Phila: in Praesentia). São Paulo: Edições Flopan, 2000.

MURAIL, T. Désintégrations (partitura). Paris: Henry Lemoine, 2004.

RUVIARO, B. Instantânea, para piano e eletrônica em tempo real (partitura). Stanford: Edição do próprio compositor, 2005.

\section{Outros}

Base de documentação sobre música contemporânea do Institut de Recherche Acoustique Musique (Ircam): <http://brahms.ircam.fr $>$.

BRUGUIÈRE, P.; DUGOT, J.; LALOUE, C.; MANIGUET, T. Le musée de la musique. Paris: Somogy Éditions d'Art, 2009.

Centro Studi Luciano Berio: <http://www.lucianoberio.org > .

Centro Tempo Reale: <www.temporeale.it/>.

Dictionnaire de la langue française, par É. Littré. Disponível em <http://www. littre.org/>.

Elettronica e Telecomunicazioni. Revista elaborada pela RAI, ano XLVII, n.2-3, dez. 1998 (republicação da edição de 1956 sobre a inauguração do Studio di Fonologia Musicale).

FERREIRA, A. B. de H. Dicionário Novo Aurélio Século XXI. Rio de Janeiro: Nova Fronteira, 1999.

Grande Dicionário Houaiss: Disponível em: <http://www.houaiss.uol.com.br/> 


\section{SOBRE O LIVRO}

Formato: $14 \times 21 \mathrm{~cm}$

Mancha: 23,7 x 42,5 paicas

Tipologia: Horley Old Style 10,5/14

Papel: Offset $75 \mathrm{~g} / \mathrm{m}^{2}$ (miolo)

Cartão Supremo $250 \mathrm{~g} / \mathrm{m}^{2}$ (capa)

1a edição: 2015

EQUIPE DE REALIZAÇÃO

Coordenação Geral

Marcos Keith Takahashi 
CULTURA

ACADÊMICA

Editona 